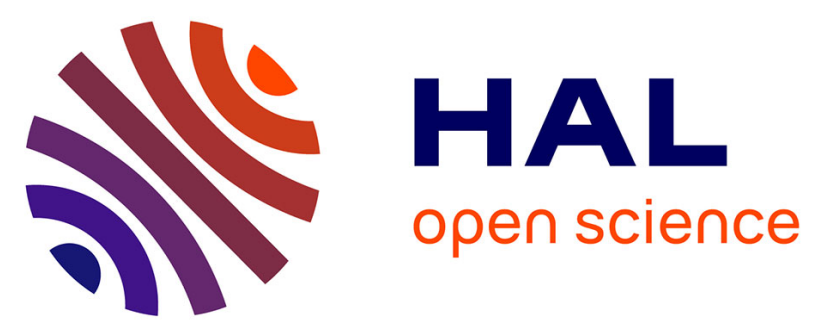

\title{
The Mount Manengouba, a complex volcano of the Cameroon Line: Volcanic history, petrological and geochemical features
}

André Pouclet, Armand Kagou Dongmo, Jacques-Marie Bardintzeff, Pierre Wandji, Pulchérie Chakam Tagheu, D. Nkouathio, Hervé Bellon, Gilles Ruffet

\section{To cite this version:}

André Pouclet, Armand Kagou Dongmo, Jacques-Marie Bardintzeff, Pierre Wandji, Pulchérie Chakam Tagheu, et al.. The Mount Manengouba, a complex volcano of the Cameroon Line: Volcanic history, petrological and geochemical features. Journal of African Earth Sciences, 2014, 97, pp.297-321. 10.1016/j.jafrearsci.2014.04.023 . insu-01010594

\section{HAL Id: insu-01010594 https://hal-insu.archives-ouvertes.fr/insu-01010594}

Submitted on 20 Jun 2014

HAL is a multi-disciplinary open access archive for the deposit and dissemination of scientific research documents, whether they are published or not. The documents may come from teaching and research institutions in France or abroad, or from public or private research centers.
L'archive ouverte pluridisciplinaire HAL, est destinée au dépôt et à la diffusion de documents scientifiques de niveau recherche, publiés ou non, émanant des établissements d'enseignement et de recherche français ou étrangers, des laboratoires publics ou privés. 
1 The Mount Manengouba, a complex volcano of the Cameroon Line:

2 Volcanic history, petrological and geochemical features

3

4

5

6

7

\section{André Pouclet $^{\mathrm{a} * *}$, Armand Kagou Dongmo ${ }^{\mathrm{b}}$, Jacques-Marie Bardintzeff ${ }^{\mathfrak{c}}$, Pierre} Wandji $^{\mathrm{d}}$, Pulchérie Chakam Tagheu ${ }^{\mathrm{e}}$, David Nkouathio ${ }^{\mathrm{b}}$, Hervé Bellon ${ }^{\mathrm{f}}$, Gilles Ruffet ${ }^{\mathrm{g}}$

a 1383, rue de la Source, 45160 Olivet, France, retired of the "Institut des Sciences de la Terre de l'Université d'Orléans", Orléans, France

${ }^{\mathrm{b}}$ Department of Earth Sciences, University of Dschang, BP 67, Dschang, Cameroon

${ }^{\mathrm{c}}$ Laboratory of Petrography-Volcanology and Planetology Team, UMR IDES 8148 CNRS, University of Paris-Sud, 91405 Orsay Cedex, France and ESPE, University of CergyPontoise, 95000 Cergy-Pontoise, France

${ }^{\mathrm{d}}$ Laboratory of Geology, Ecole Normale Supérieure, University of Yaounde-1, BP 47, Yaoundé, Cameroon

e Department of Earth Sciences, University of Yaoundé-1, BP 812, Yaoundé, Cameroon

${ }^{\mathrm{f}}$ Laboratory of Geochronology, University of Bretagne Occidentale, CS 93637, 29238 Brest Cedex 3, France

${ }^{\mathrm{g}}$ CNRS (CNRS/INSU) UMR 6118, Géosciences Rennes, 35042 Rennes Cedex, and Université de Rennes I, Géosciences Rennes, 35042 Rennes Cedex, France

* Corresponding author.

E-mail address: andre.pouclet@sfr.fr

Keywords: Cameroon Volcanic Line, Manengouba volcano, alkaline magmatism, Quaternary volcanism, K/Ar and ${ }^{40} \mathrm{Ar} /{ }^{39} \mathrm{Ar}$ age dating, Caldera collapse, Olivine and pyroxene thermobarometry, $\mathrm{Sr}-\mathrm{Nd}$ - $\mathrm{Pb}$-isotopes, Mantle source components

\section{ABSTRACT}

The volcanic story of Mount Manengouba is related to four chronological stages: 1) forming of the early Manengouba shield volcano between 1.55 and $0.94 \mathrm{Ma}, 2$ ) building of the Eboga strato-cone between 0.94 and $0.89 \mathrm{Ma}, 3$ ) caldera collapse and silicic extrusions of the 
34 Elengoum Complex between 0.89 and $0.70 \mathrm{Ma}$, and 4) intra-caldera and flank activity

35 between 0.45 and $0.11 \mathrm{Ma}$. The volume of the volcano is calculated at $320 \mathrm{~km}^{3} \pm 5 \%$. The

36 volcanic rocks are attributed to two magmatic outputs. The first and main magma generation

37 produced the shield volcano, the strato-cone, and the syn- to post-caldera extrusions, displaying a complete series from basanites to trachytes (magmatic Group 1). The second magma generation is limited to the late and flank activity evolving from basanites to trachyphonolite (magmatic Group 2). Both magmatic groups belong to the under-saturated alkaline sodic series. Petrological calculations locate the magmatic reservoir between 37 and $39 \mathrm{~km}$ in the upper mantle for the Group 1 lavas, and between 42 and $44 \mathrm{~km}$ for the Group 2 lavas. Trachytes were generated in a secondary crustal reservoir. Magmatic series evolve with medium to low pressure fractional crystallization of olivine, pyroxene, oxides, feldspar, and apatite. Significant crustal assimilation is evidenced in trachytes. The magma of Group 1 was generated with 3 to $6 \%$ of partial melting of a moderately enriched source containing 3 to $7 \%$ of garnet. Melting took place in the spinel to garnet transition zone located at 70 to $90 \mathrm{~km}$ and around $25 \mathrm{~kb}$. The magma of Group 2 resulted from a slightly higher partial melting from a less garnet-rich source that indicates uprising of the melting column in the upper part of transition zone. $\mathrm{Sr}, \mathrm{Nd}$, and $\mathrm{Pb}$ isotope data of the Manengouba rocks and neighbouring lavas are analyzed and compared with those of the mafic lavas of the CVL. Three source components are distinguished: a depleted component originated from the asthenospheric swell, a radiogenic component linked to the contaminated lithosphere of the Neoproterozoic mobile belt, and an enriched component or the lithosphere possibly related to pre-rifting magmatic processes.

\section{Introduction}

Mount Manengouba is one of the great continental volcanoes of the Cameroon Line, consisting of the Mts Cameroon, Bambouto, Bamenda, and Oku (Fig. 1). The Cameroon Line

61 is a transtensional passive rift, showing an alternation of volcanic horsts and grabens (Moreau 62 et al., 1987; Meyers et al., 1988; Déruelle et al., 2007). Tectonic extension caused lithospheric thinning, asthenospheric upwelling and the formation of a magmatic hot line, trending $\mathrm{N} 30^{\circ} \mathrm{E}$. An important volcanic activity took place along the Line, from the Eocene to recent times (Déruelle et al., 1991). Present activity is restricted to Mount Cameroon (Wandji et al., 2009) and Bioko Island, but numerous Quaternary eruptions have occurred in the volcanic areas of 
Dongmo et al., 2001; Nkouathio et al., 2002; Suh et al., 2003; Itiga et al., 2004; Wotchoko et al., 2005; Kagou Dongmo et al., 2010).

The Mount Manengouba is located 120 km north-east of Mount Cameroon, between $09^{\circ} 42^{\prime}$ to $10^{\circ} 10^{\prime} \mathrm{E}$, and $4^{\circ} 49^{\prime}$ to $5^{\circ} 15^{\prime} \mathrm{N}$ (Fig. 2). It mainly consists of a shield volcano overlain by a stratovolcano that culminates at $2411 \mathrm{~m}$ and covers $500 \mathrm{~km}^{2}$. It is set up on a volcano-tectonic height trending $\mathrm{N} 30^{\circ} \mathrm{E}$ above the uplifted granite basement and crosscut by $\mathrm{N} 0^{\circ}, \mathrm{N} 30^{\circ}$ to $50^{\circ} \mathrm{E}$ and $\mathrm{N} 140^{\circ} \mathrm{E}$ faults. Along this height, there is an alternation of horst and graben structures. The Manengouba volcano emplaced at the northern end of the Tombel graben in the sedimentary Manjo and Mbo plains limited by two $\mathrm{N} 30^{\circ} \mathrm{E}$ trending normal faults: the Tombel Fault to the west and the Nlonako Fault to the east (Fig. 1B).

Since Gouhier et al. (1974), Tchoua (1974), Dunlop (1983), and Fitton and Dunlop (1985), a volcanological pattern has been assumed for the Manengouba building. The Mount Manengouba was built between 1.55 Ma and 0 Ma during three stages (Kagou Dongmo, 1998, 2006; Kagou Dongmo et al., 2001). The first stage, from 1.55 to 0.7 Ma, corresponds to the formation of a basaltic shield volcano evolving to a stratovolcano named Elengoum, which was capped by trachyte domes and flows. The second stage, between 0.7 and $0.56 \mathrm{Ma}$, points to the collapse of the Elengoum summit that created a large caldera which opened to the west. The third stage, from $0.56 \mathrm{Ma}$ to recent time, includes the building-up of a new stratovolcano named Eboga inside the caldera. Then the collapse of the Eboga summit formed the Eboga caldera enclosed in the former caldera of Elengoum. Finally, since 0.48 Ma, numerous flank eruptions, mainly basaltic, supplied lava flows on the Manengouba slopes. The volcanic rocks belong to the alkaline sodic series, evolving from basanite to trachyte.

Conducting new mapping, we established geological contradictions with the commonly accepted history of the volcanic activity. New sample analyses were done and new ages were obtained by K/Ar and ${ }^{40} \mathrm{Ar} /{ }^{39} \mathrm{Ar}$ methods. These data led to a complete revision of the conventional Manengouba history. Petrological and magmatic features are documented from mineral and chemical analyses. Trace elements and $\mathrm{Sr}, \mathrm{Nd}$, and $\mathrm{Pb}$ isotopes are used to constrain the magma source composition.

\section{The Manengouba volcano, reappraisal of the volcanic history}

The geological pattern of the volcano has been reviewed. A new map is drawn, using recent aerial photographs, suitable satellite imagery and field work surveys. The reduced map is given on Figure 2 and detailed on Figures 3 and 4. 


\subsection{The pre-Manengouba formations}

104 The lavas of the basal shield volcano overflowed the Cretaceous and Quaternary lacustrine

105

106

107

108

109

110 and fluvial sediments of the northern end of the Tombel Graben. The Precambrian granite basement is exposed on the SW, S, E, and NE sides. The south-eastern border was intruded by a small syenite intrusion and associated rocks, the Mount Nlonako (Fig. 2), in middle Eocene between 43-46 Ma according to K-Ar age geochronology by Tchoua (1974) and Cantagrel et al. (1978). A similar intrusion, the Mount Koupé took place to the south-west of the Manengouba area (Fig. 1) and is dated at $53 \mathrm{Ma}$ ( $\mathrm{Rb} / \mathrm{Sr}$ isotopic age in Lamilen, 1989). These intrusions belong to the Cretaceous to Eocene alkaline complex alignment from the Gulf of Guinea to the Lake Chad and betray the initial magmatic activity of the Cameroon tectonic line (Moreau et al., 1987; Déruelle et al., 1991). The north-western area exhibits thick ignimbritic flows and abundant extrusive domes of phonolite and trachyte that built Mounts Bakossi and Ekomane on both sides of the Bangem breach. Similar lavas are disseminated as small outcrops to the north and south of the Manengouba area. Previous dating of a trachyte dome of Ekomane yields a Middle Miocene age (Dunlop, 1983). These volcanic products can be related to the Miocene acidic activity of Mount Bambouto, north of Mount Manengouba (Youmen et al., 2005; Kagou Dongmo et al., 2010). A noticeable sight of this work is the discovery of old mafic lavas preserved along the western base of the Nlonako hill by means of tectonic uplift. The first flows of Manengouba came into contact with these pre-Manengouba lavas while the youngest flows from flank cones covered some parts of them. These later young lavas include 5 to $10 \mathrm{~cm}$ sized angular xenoliths of the old mafic lavas, indicating that these old lavas are set beneath Mount Manengouba. A new age dating is provided.

\subsection{The Manengouba formations}

Taking into account the piling up of different volcanic formations of Mount Manengouba, we distinguished four main chronological units and formational stages from the early shield volcano to the late flank lavas.

\section{1) The early Manengouba shield volcano}

The oldest lavas crop out all around the main building on the middle and low slopes. They consist of stacked lava flows of ankaramite, basalt and hawaiite. Spectacular stacking of these lavas can be seen in the canyon of the Nkam river, at the Ekom Nkam water fall, north-east of the Manengouba field (Fig. 2). These lavas belong to a large shield volcano that was the 
136 primary Manengouba building. They are capped by more evolved lavas of the upper volcanic

137 edifice and overlain by numerous parasitic cones and their lava flows.

138

139

140

141

142

143

144

145

146

147

148

149

150

151

152

153

154

155

156

157

158

159

160

161

162

163

164

165

166

167

168

169

2) The Eboga stratovolcano

The upper mountain is a stratovolcano named Eboga and made of alternating, more evolved lavas flows and pyroclastic deposits. The lava composition is dominated by mugearites though hawaiites and benmoreites also occur. The northern and north-eastern upper flanks are covered by benmoreite flows. The summit of the edifice collapsed in a roughly circular caldera, averaging $4 \mathrm{~km}$ in diameter (Fig. 3). An arc-shaped scarp to the north-eastern upper slope is attributed to this collapse event and not to a former caldera because the scarp plan crosscut the Eboga flows that have outpoured from the initial crater. The caldera was filled with basaltic flows contemporaneously with the late flank volcanic activity until its north-western breach. Thus, the extent of the sinking event is unknown as well as the height of the initial crater rim. The present day height of the caldera wall reaches $200 \mathrm{~m}$.

The formation of the Eboga cone is the continuation of the activity of the early shield volcano assuming a magmatic evolution from fluid mafic lavas to more viscous differentiated lavas.

\section{3) The Elengoum Extrusive Complex}

The Eboga south-eastern upper slope is overlapped by thick trachyte pyroclastic flows and benmoreite to trachyte domes which constitute the Elengoum Extrusive Complex (EEC).

Numerous bodies of similar composition extruded the summit part of the Eboga, and particularly the caldera wall in using the circular faults of the caldera and the north-eastern arc-shaped fault (Fig. 3). Consequently it is obvious that the formation of the EEC postdates the formation of the Eboga cone. Definitely, the Elengoum cannot be attributed to a preEboga volcanic stage. One may assume that the Elengoum trachytic lava withdrawal of the magma chamber was linked to the Eboga caldera collapse. The tectonic location of the EEC is controlled by the major SW-NE trending fracture system (Fig. 2).

A singular acidic dome, the Ekom rhyolite extrusion, seems to intrude the basalt flows of the early Manengouba shield at the north-eastern lower slope. The meaning of this activity is questionable.
4) Flank cones and flows 
All around the main cone but also on the upper flanks and inside the caldera, ca. one

171

172

173

174

175

176

177

178

179

180

181

182

183

184

185

186

187

188

189

190

191

192

193

194

195

196

197

198

199

200

201

202

203

hundred parasitic and monogenetic cones are set up along short fractures, mainly trending SW-NE and WSW-ENE. The cones resulted from common strombolian activities and supplied lava flows of one to ten kilometres in length. In addition, three maar volcanoes are pointed out: one on the eastern upper flank and two inside the caldera (DS, LF and LH in Figure 3). The intra-caldera maars were emplaced along a SW-NE fracture, formerly used by the $\mathrm{C} 2$ strombolian cone, and two trachytic extrusions of the caldera wall. Indeed, they postdate the two strombolian cones $\mathrm{C} 1$ and $\mathrm{C} 2$, because their volcaniclastic debris covered the cones. In addition, a plug-dome named Mboriko extruded the caldera floor along a short SSW-NNE fracture. A significant amount of cones took place in the eastern upper slope, namely the supra-caldera strombolian volcanic complex (SCSV, Fig. 3) and the strombolian cone set above the caldera edge that is the summit of Mount Manengouba at 2,411 m. Most of the lavas are basanites and hawaiites, whilst mugearites are also common.

Assuming that Mount Manengouba rests above the granitic substratum that crops out to the west, south, and east, the total volume of the volcano is calculated at $320 \mathrm{~km}^{3} \pm 5 \%$.

On the base of the features of volcanic activities, the mafic to evolved lavas of the early shield volcano (Eboga volcano and Elengoum Complex) may belong to a single magmatic series. In return, the activity of flank cones requires a new magma supply. Compared to the volcano main building (stages 1 to 3 ), the volume of late flank lavas (stage 4) is very weak and estimated between 1.5 to $2 \mathrm{~km}^{3}$.

\section{Chronological data}

A total of eight lavas are dated by the K/Ar method and six by the ${ }^{40} \mathrm{Ar} /{ }^{39} \mathrm{Ar}$ method (Table 1). All these new age data as well as the previous ones are located on Figures 2, 3, and 4. The ${ }^{40} \mathrm{Ar} /{ }^{39} \mathrm{Ar}$ plateau ages are plotted in Figure 5. The complete available geochronological data for the Manengouba area are given in Table 2.

The oldest ages are devoted to volcanic rocks emplaced before the formation of the Manengouba volcano. They concern trachyte and phonolite extrusions related to a thick acidic volcanic pile at the north-western border of the Manengouba area. Two new Miocene ages, $13.56 \pm 0.39$ and $7.55 \pm 0.18 \mathrm{Ma}$, are provided for a trachyte extrusion of the Ekomane Mounts and for a phonolite extrusion of the Bakossi Mounts, respectively (Fig. 4). A slightly younger age, $11.82 \pm 0.47 \mathrm{Ma}$, was obtained by K/Ar method for a trachyte of the Ekomane 
area (Table 2; Dunlop, 1983). In addition, a few old mafic lava flows are preserved at the western lower flanks of the Eocene syenite intrusion of Nlonako, which is the south-eastern border of the Manengouba. One of these flows of hawaiite composition is dated at $9.37 \pm 0.05$ Ma (Fig. 3).

A particular volcanic activity occurred at the eastern edge of the Manengouba field close to Ekom. It consists of a rhyolite extrusion a few hundred metres wide (Fig. 2) that we dated at $1.02 \pm 0.03$ Ma. Relationships with the surrounding basalts are unknown.

The oldest Manengouba lava that we analyzed is a trachyte extrusion of the Elengoum Extrusive Complex, eastern upper flank of Manengouba. It is dated at $0.89 \pm 0.02 \mathrm{Ma}$ (Fig. 3). This age is consistent with that of an Elengoum trachyte formerly dated at $0.70 \pm 0.01 \mathrm{Ma}$ (Table 2; Kagou Dongmo et al., 2001) but geological study demonstrates that the Elengoum extrusions are late activities of Mount Manengouba. Older ages have been measured for basaltic lavas constituting the lower flanks of Manengouba and belonging to the early shield volcano. These basalts are dated at $1.55 \pm 0.10$ and $0.94 \pm 0.06 \mathrm{Ma}$, south-west of Nkongsamba in the south-eastern Manengouba field (Table 2; Gouhier et al., 1974; Dunlop, 1983). These basalts are overlain by the Elengoum trachyte flows.

All the other and younger ages concern the flank volcanic activity. According to both new and previous age dating, this activity began at the north-western and northern slopes with the hawaiite eruptions of Mboassoum and Melong dated at $0.45 \pm 0.07$ and $0.45 \pm 0.04 \mathrm{Ma}$ respectively (Figs. 2 and 4). It continued with the mugearite eruption of Nyam at $0.40 \pm 0.23$ Ma, north-western slope, the basanite eruption of Njinjo at $0.40 \pm 0.04 \mathrm{Ma}$ (northern slope), the alkaline basalt eruption of the cone of Manengouba-village at $0.22 \pm 0.10 \mathrm{Ma}$ (southern flank), the hawaiite eruption at $0.20 \pm 0.10 \mathrm{Ma}$ on the south-eastern flank, and the basanite eruption of Ekoh at $0.11 \pm 0.03 \mathrm{Ma}$ (eastern flank) (Figs. 2, 3 and 4). A singular extrusive trachy-phonolite activity at the north-western slope is dated at $0.21 \pm 0.02 \mathrm{Ma}$. In the same time, hawaiite eruptions occurred inside the Eboga caldera with the formation of two groups of strombolian cones to the south-east $(\mathrm{C} 1)$ and the west $(\mathrm{C} 2)$ and the covering of the caldera floor (Fig. 3). The $\mathrm{C} 1$ flow is dated at $0.36 \pm 0.13$ and $0.33 \pm 0.02 \mathrm{Ma}$, and the $\mathrm{C} 2$ flow is dated at $0.16 \pm 0.07 \mathrm{Ma}$. This strombolian activity was followed by two phreatomagmatic explosions that created two maars named "lac de la femme" and "lac de l'homme" (LF, LH, Fig. 3), and by the Mboriko plug-dome extrusion.

$$
\text { In summary, the volcanic story of Mount Manengouba is written in four chronological }
$$
stages that are sketched in a schematic WNW-ESE cross-section of the volcano in Figure 6. 
Stage 1) The early Manengouba shield volcano was initiated between 1.55 and $0.94 \mathrm{Ma}$

239

240

241

242

243

244

245

246

247

248

249

250

251

252

253

254

255

256

257

258

259

260

261

262

263

264

265

266

267

268

269

270

271 with piling-up of basaltic lava flows. Few data are available concerning these lavas because they have been neglected in the field studies at the benefit of the more attractive strombolian cones and flows at the flanks.

Stage 2) Building of the Eboga central volcano took place between 0.94 and 0.89 Ma. The stratovolcano was fed by evolved magma from the main reservoir, in a continuation of the shield volcano activity.

Stage 3) Draining of the reservoir and caldera collapse were linked to benmoreitic and trachytic extrusions from 0.89 to $0.70 \mathrm{Ma}$. Most of the extrusions were emplaced in a SW-NE trending fracture zone of the south-eastern upper slope, namely the Elengoum Extrusive Complex. Some extrusive activities were drained by the caldera sink faults and by the associated sub-circular fault at the north-eastern flank. The total volume of acidic deposits is estimated ca. $20 \mathrm{~km}^{3}$.

The meaning of the Ekom rhyolite extrusion dated at 1.02 Ma is unknown. It is impossible to relate this highly evolved product to any Eboga activity. More field work is needed and the age dating must be improved.

Stage 4) Renewal of the volcanic activity began at $0.45 \mathrm{Ma}$ and lasted until 0.11 Ma. Lava poured out along flank fractures and inside the caldera. It can be assumed that the main conduit of the initial crater was blocked up by the collapsed rocks of the caldera and acidic intrusions. A small volume of lava reached the caldera but most of the lavas were drained by middle to lower slope fractures. The magma composition evolved from basanites to mugearites and few trachy-phonolites. No time or space distribution of the different rock compositions can be evidenced. Such a volcanic activity requires a renewal of the magma production and the tectonic stress after the emptying of the Eboga reservoir with the extrusion of the last evolved products.

Obviously this story is a rough draft of more than one million years of volcanic activity. Very few data are known of the primary shield. No precise dating is available for the Eboga cone building. Relationships between the two collapses of the north-east fault scarp and of the caldera are not clear. It is not sure that the acidic extrusions of Elengoum Complex and the caldera rim are contemporaneous. However, it is clear that the caldera belongs to the Krakatoan or plate/piston type (Cole et al., 2005) and was due to a single main collapse event. According to Acocella (2007), the north-eastern curved scarp can be interpreted as an outer ring fault of the stage four of the evolution of caldera collapse. Regarding the post-caldera activity with extrusion of acidic domes at the caldera rim and further setting of mafic vents on 
272 the floor that was covered with basaltic flows, the caldera is classified as type-MS and type-L

273 of Geyer and Marti (2008). We assume that this caldera resulted from the collapse of a strato-

274 cone that culminated circa 2,500 $\mathrm{m}$ according to a crater diameter of $1 \mathrm{~km}$ (Fig. 6). The depth

275 of the collapse is unknown. For calderas of the same size, measured diameter/subsidence (d/s)

276 ratios range from 5 to 10 (Acocella, 2007). An average value of 7.5 is best estimated referring

277 to many volcanoes of Galapagos, Azores, Canaries, and Cape Verde of similar size and shape

278 (Mitchell-Thomé, 1980; Munro and Rowland, 1996; Caldera Data Base of Geyer and Marti,

279 2008). The initial floor of the caldera was thus ca. $530 \mathrm{~m}$ below the present rim. It is doubtful

280 that the acidic domes of the caldera margins took place at such a low level. Owing to their

281 shapes, their bases are less than $50 \mathrm{~m}$ deep below the present basaltic floor. These domes

282 probably extruded at the final stage of an acidic activity that has supplied ignimbrite flows

283 filling the caldera (Fig. 6, Stage 3b). The calculated volume of the acidic caldera filling could

284 be estimated between 1.5 and $2 \mathrm{~km}^{3}$.

285

286

4. Composition of volcanic rocks

287

288

289

290

291

292

In agreement with the volcanic story, the volcanic rocks of Manengouba can be attributed to two successive magmatic outputs. The first magma generation produced the primary shield volcano, the Eboga stratovolcano, and the syn- to post-caldera extrusions. It yields the magmatic Group 1, displaying a complete series from basanite to trachyte. The second

293 generation was responsible for the formation of the flank cones and flows. It corresponds to the magmatic Group 2, evolving from basanite to mugearite and trachy-phonolite. The preManengouba volcanic rocks consist of trachytes and phonolites to the western side, and of hawaiites and mugearites to the eastern side.

The mineral compositions have been analyzed with electron probe microanalyzers Cameca SX50 at the University of Orléans and the University of Paris-VI (France). The main results are summarized in Table 3A and 3B. Selected analyses of minerals are listed in Tables 4A to 4G. The rocks have been analyzed by ICP-AES and ICP-MS at the analytical laboratory of CRPG-CNRS of Nancy (France). The Table 5 displays the complete set of chemical analyses. Most of the petrographical data have been acquired during the work for the $\mathrm{Ph}$. $\mathrm{D}$. theses of thesis of Kagou Dongmo (2006). 
Both magmatic groups belong to the under-saturated, alkaline sodic series, although the intermediate terms overlap with the sodic-potassic limit and the acidic terms are fairly potassic. In the TAS diagram (La Bas et al., 1986), the Group 1 displays a continuous trend from basanites to trachytes (Fig. 7). The Group 2 evolves from basanites to basaltic trachyandesites or mugearites, though one trachy-phonolite dome is pointed out. We use the nomenclature of the common sodic series and chemical cut based on the Differentiation Index (DI) of Thornton and Tuttle (1960). This system has the double benefit of regularly dividing the series and easily naming rocks according to chemical analyses. The mafic rocks evolve from basanites or alkaline basalts (limit at $\pm 5 \%$ of normative nepheline) to hawaiites. A few mafic lavas are enriched in cumulative olivine and clinopyroxene phenocrysts and are termed ankaramites. The intermediate lavas are composed of mugearites and benmoreites with no compositional gap. The more evolved lavas consist of oversaturated trachytes.

The petrographical features of Group 1 lavas are displayed in Table 3A. The more mafic lavas consist of ankaramites, basanites and alkaline basalts. Their textures are hyalo-microlitic and more or less porphyritic with 10 to 15 vol.\% of olivine, pyroxene, and plagioclase phenocrysts or microphenocrysts, and magnetite microphenocrysts, sometimes included in clinopyroxene. The same minerals crystallized in the groundmass in addition with apatite and ilmenite in a vitreous matrix. The hawaiites have similar textures with varying abundance of phenocrysts. They are characterized by a higher amount of plagioclase. The mugearites are hyalo-microlitic and more or less rich in microphenocrysts of olivine, clinopyroxene, and plagioclase plus Ti-rich amphibole and rare phlogopite. The benmoreites contain few microphenocrysts of olivine and clinopyroxene, but abundant laths of sodic plagioclase. Clots of olivine, clinopyroxene, plagioclase, and oxides are frequent. The trachytes show a common trachytic texture with laths of anorthoclase and microphenocrysts of clinopyroxene. mafic rocks.

\section{Olivine}


Olivine phenocrysts of basanites and alkaline basalts are moderately zoned. Their Fo contents range from 81.7 to 77.1, from core to rim. The Fo 78.4-74.1 compositions of microcrysts share alike the phenocryst rim compositions. Phenocrysts of hawaiites are also zoned Fo 79.0-69.0, and have the composition of the basalt microcrysts. Microcrysts show significant iron enrichment: 70.5-57.9. The same pattern is recorded with the phenocrysts of mugearites and benmoreites having Fo 68.7-65.2 and Fo 67.5-58.3, respectively, and with their microcrysts having Fo59.6-55.0 and Fo55.0-51.3. This is consistent with a continuous differentiation of a batch of magma involving drastic decrease of the Mg content as a result of olivine fractionation.

A few xenocrysts are recorded in basanites. Their Fo (85.2-84.5) and $\mathrm{CaO}(0.30-0.25$ wt.\%) contents indicate that they are inherited from melt rather than entrained mantle xenocrysts. They probably crystallized in the more primitive magma. Xenocrysts are frequent in hawaiites. Their Fo (84.5-83.2) and $\mathrm{CaO}(0.28-0.23$ wt.\%) contents also indicate that they are inherited from melt. They have the same composition as the xenocrysts and phenocrysts of basanites. They then were fractionated from the previous more primitive batch of magma that has generated the basanites and alkali basalts of the basal shield volcano. Similarly, mugearites enclose xenocrysts Fo 77.4-74.8 that may have been extracted from the hawaiite magma. The benmoreites also contain xenocrysts Fo 68.5-66.5 originated from the mugearite magma. However we cannot discard a post-olivine crystallization modification of the liquid by crustal assimilation and Mg\# decrease (see Geochemical Chapter). We assume that xenocrysts were removed from the walls of the main magma reservoir where olivines precipitated with decreasing temperature, causing differentiation of the inner magma continuously depleted in magnesium.

Compositions of olivines are plotted in a Fo\% vs. $\mathrm{CaO}$ (wt.\%) diagram (Fig. 8A). Phenocrysts, microcrysts, as well as xenocrysts crystallized from a related suite of magmas. The diagram showing the Mg\# of lava vs. Fo contents of olivine (Fig. 9) allows to distinguish xenocrysts, phenocrysts and microcrysts. The olivine-liquid equilibrium temperature is calculated using the equation (4) of Putirka et al. (2007). The temperature decreases from $1300^{\circ} \mathrm{C}$ for the initial basaltic composition to $1250^{\circ} \mathrm{C}, 1180^{\circ} \mathrm{C}$, and $1080^{\circ} \mathrm{C}$, while the inner residual batch of magma evolves from hawaiite to mugeanite, and benmoreite composition. The liquid temperature calculated after the equation (15) of Putirka (2008) decreases from $1230^{\circ} \mathrm{C}$ to $1190^{\circ} \mathrm{C}, 1100^{\circ} \mathrm{C}, 1085^{\circ} \mathrm{C}, 1070^{\circ} \mathrm{C}$, and $1025^{\circ} \mathrm{C}$, from basanite to benmoreite.

\section{Magnetite and ilmenite}


Magnetite phenocrysts of basanites and alkali basalts are titaniferous and rich in

375

376

377

378

379

380

381

382

383

384

385

386

387

388

389

390

391

392

393

394

395

396

397

398

399

400

401

402

403

404

405

406

407 magnesium and aluminium but poor in chromium. The mole content is dominated by magnetite, Mg-magnetite or Mg-ferrite and ulvöspinel. The spinel component is limited by the $\mathrm{Al}$ amount. Exceeding $\mathrm{Mg}$ substitutes to $\mathrm{Fe}^{2+}$ in magnetite. From alkaline basalts to benmoreites, spinel mole decreases and ulvöspinel slightly increases. Magnetite mole increases in hawaiites but decreases in benmoreites. Mg-ferrite evolves reversely. Microcrysts of trachytes are pure Ti-magnetite, devoid of aluminium and magnesium.

In Figure 10, magnetite compositions display a positive correlation of $\mathrm{Ti} /(\mathrm{Ti}+\mathrm{Al}+\mathrm{Cr})$ and $\mathrm{Fe}^{2+} /\left(\mathrm{Fe}^{2+}+\mathrm{Mg}\right)$ ratios from basalts to trachytes due to decreasing $\mathrm{Al}$ and $\mathrm{Mg}$ contents in the evolved magmas.

Ilmenites are rare in the basaltic rocks. They constitute of more or less abundant microphenocrysts and microcrysts in hawaiites, mugearites, and benmoreites of the Eboga middle and upper slopes. From hawaiites to benmoreites, they display a decreasing amount of the ilmenite component $\left(0.95<X_{\text {ilm }}^{\prime}<0.87\right)$, calculated after Stormer (1983), and a concomitant increasing amount of the hematite phase and the $\mathrm{Fe}^{3+} / \mathrm{Fe}^{2+}$ ratio value $(0.12<$ $\left.\mathrm{Fe}^{3+} / \mathrm{Fe}^{2+}<0.34\right)$. Ilmenites are limited to few crystals in benmoreites and trachytes of the Elengoum extrusions and show a composition close to pure ilmenite.

Coexisting magnetites and ilmenites have been analyzed in hawaiites, mugearites and benmoreites. The oxygen fugacity $f_{\mathrm{O} 2}$ is estimated from the mole fraction of ulvöspinel $\mathrm{X}_{\text {Usp }}^{\prime}$ in magnetite and of ilmenite $X^{\prime}$ llm in ilmenite, calculated after Stormer (1983), and using the parameters of Andersen and Lindsley (1988). In hawaiites, $\log f_{\mathrm{O} 2}$ averages $-13.7 \pm 0.5$ close to the $\log f_{\mathrm{O} 2}(\mathrm{FMQ})$ value $\left(\Delta \log f_{\mathrm{O} 2}(\mathrm{FMQ})=0\right)$. In mugearites, $\log f_{\mathrm{O} 2}$ ranges from -13.5 to 12.1 with $\Delta \log f_{\mathrm{O} 2}(\mathrm{FMQ})=0$. In benmoreites, $\log f_{\mathrm{O} 2}$ ranges from -10.8 to 10.5 with $\Delta \log f_{\mathrm{O} 2}$ $(F M Q)=+0.5$. These results are consistent with an increase of the oxygen fugacity fairly above the fayalite-magnetite-quartz buffer.

\section{Clinopyroxene}

A large set of Group 1 pyroxenes have been analyzed in fourteen samples of basanites to trachytes including xenocrysts, phenocrysts and microcrysts. To illustrate the various types of analyzed crystals, pyroxenes are plotted in the temperature vs. $\mathrm{K}_{\mathrm{D}}(\mathrm{Fe}-\mathrm{Mg})$ diagram of Putirka et al. (2003; Figure 5), using the liquid temperature as calculated after equation (15) of Putirka (2008) and consistent with the olivine-liquid equilibrium temperature (Fig. 11). There is a continuous range of composition of phenocrysts from basanites to benmoreites.

Xenocrysts are rare in basanites but frequent in hawaiites, mugearites, and benmoreites. The 
408

409

410

411

412

413

414

415

416

417

418

419

420

421

422

423

424

425

426

427

428

429

430

431

432

433

434

435

436

437

438

439

440

441

analyzed pyroxenes of the more evolved mugearites and of benmoreites are mainly glomerocrysts from aggregates of olivine, magnetite, and feldspar. The test for equilibrium of Putirka et al. (2003) and Putirka (2008) (observed pyroxene compositions compared to calculated compositions) indicates that pyroxenes of the more evolved benmoreites and trachytes can be phenocrysts.

Conventional pyroxene compositions are shown in the Mg-Ca-Fet+Mn diagram (Fig. 12). Two broadly separated clusters are found, one for basanite to benmoreite rocks and one for trachyte. The first cluster overlaps the diopside-calcic augite boundary. Details of the composition ranges of the various types of crystals are given in Table 3A. There is a limited evolutionary trend from phenocrysts of basanite to microcrysts of mugearite with a moderate decrease in $\mathrm{Mg}$ and $\mathrm{Ca}$. The more magnesian crystals are xenocrysts of basanite and hawaiite. Owing to their Mg-Fe contents, these xenocrysts were inherited from a melt rather than the mantle. They probably crystallized in the more primitive magma. Most of the phenocrysts of the less evolved benmoreite are glomerocrysts. One may note that xenocrysts and glomerocrysts of this benmoreite have the same composition like phenocryts of hawaiite and mugearite. This feature reinforces the assumption also given by the olivines that the xenocrysts were removed from the margins of the main magma reservoir where liquids differentiated.

Pyroxenes of trachytes display a sharply different composition while plotting in the hedenbergite to calcic augite area. They contain low amount of $\mathrm{Na}_{2} \mathrm{O}(0.7-1.6 \mathrm{wt} . \%)$ despite belonging to the quadrilateral pyroxenes $(100 \mathrm{Di}+\mathrm{Hd} / \mathrm{Jd}+\mathrm{Ac}=86-94)$. Taking into account the large compositional gap between the basanites and benmoreite pyroxenes, it can be concluded that the trachytes were not generated in the main magma reservoir.

Additional compositional data of the pyroxenes are given with the $\mathrm{Al}^{\mathrm{IV}}$ vs.. $\mathrm{Al}^{\mathrm{VI}}$, Ti vs.. $\mathrm{Al}^{\mathrm{VI}}$, and Ti vs.. Na diagrams (Fig. 13). First, there are no pyroxenes inherited from mantle peridotites. Xenocrysts as well as phenocrysts and microcrysts crystallized from magmas in the course of the differentiation. $\mathrm{Al}^{\mathrm{IV}}, \mathrm{Al}^{\mathrm{VI}}$, and Ti decrease from basanites to benmoreite in relationship to the decreasing content of jadeite, esseneite, and Ti-tschermakite at the benefit of ferrosilite. The Ca-tschermakite mole does not play a significant role. The Ti-Na diagram indicates that pyroxenes of trachytes crystallized in a distinct batch enriched in $\mathrm{Na}$.

To provide clues to the depth of crystallization of the magma, we applied the clinopyroxene-liquid thermobarometer of Putirka et al. (2003). The barometer is based on jadeite crystallization and jadeite-diopside + hedenbergite exchange equilibria and is temperature dependent. It is appropriate for volatile-bearing lava compositions. Here, we used 
442 the $\mathrm{FeO}$ calculated contents and not the total $\mathrm{FeO}$ for rocks and pyroxenes because ferric iron

443 cannot be neglected in natural samples. The less porphyritic mafic lavas are considered,

444 discarding cumulate rocks to avoid hazardous subtraction of the olivine phase. We selected

445 analyses of the core of phenocrysts, yielding a $\mathrm{K}_{\mathrm{D}}(\mathrm{Fe}-\mathrm{Mg})$ in equilibrium with the lava when

446 close to the initial liquid composition (0.275; Putirka et al., 2003). Xenocrysts and mantled or

447 rimed phenocrysts are thus eliminated. Equations of Model A (pressure) and Model B

448 (temperature) are solved simultaneously. Satisfying results are achieved when both models

449 yield similar values, with the temperature estimation close to the calculated liquid temperature

450 according to Putirka (2008). Calculated pressures range from 10.5 to $11.3 \pm 1.7 \mathrm{kbars}$.

451 Iterative calculations yield somewhat lower P estimations of 9.4 to $10.6 \mathrm{kbars}$, but with a

452 temperature $30^{\circ} \mathrm{C}$ below the calculated liquid temperature. In the continental Cameroon

453 Volcanic Line, the crustal thickness averages $35.5 \mathrm{~km}$ using 1-D shear wave velocity models

454 (Tokam et al., 2010). In the Manengouba area (station CM15 of Tokam et al., 2010) a more

455 precise value of $33 \mathrm{~km}$ is calculated. With this crustal thickness, the pyroxene barometer

456 allows locating the crystallization depth between 37 and $39 \mathrm{~km}$ in the upper mantle for the

457 accurate temperature calculation, or between 33.5 and $37 \mathrm{~km}$ slightly below the Moho, for the

458 iterative calculation.

459

460

461

462

Amphibole and mica

463

microphenocrysts. They consist of edenite or kaersutite, depending on their increasing content

of $\mathrm{TiO}_{2}$. Their $\mathrm{Mg} / \mathrm{Mg}+\mathrm{Fe}^{2+}$ ratios and $\mathrm{TiO}_{2}$ contents are ranging from 0.86-0.89 and 2.1-2.2

464

wt.\% for edenite, and from 0.66-0.77 and 5.6-6.2 for kaersutite. The Ti-rich amphiboles are

465

phenocrysts of the more evolved mugearitic lavas.

466 Biotites occur in mugearites and benmoreites of the Eboga upper slopes and comply with a

467 Ti-rich phlogopite composition $\left(0.79<\mathrm{Mg} / \mathrm{Mg}+\mathrm{Fe}^{2+}<0.83 ; 3.5<\mathrm{TiO}_{2}\right.$ wt $\left.\%<3.9\right)$.

469 Feldspar

470 Phenocrysts and microcrysts of plagioclases are common phases and display a complete

471 calcic to sodic compositional trend from basanites to evolved lavas. Phenocrysts of basanites

472 and alkaline basalts are zoned $\mathrm{An}_{66-60}$ and microcrysts have the $\mathrm{An}_{60-51}$ composition close to

473 the phenocryst rim. Some lavas contain corroded xenocrysts An 51-40, which are inherited

474 from a former, evolved magma. In the compositional range of hawaiites, phenocrysts vary

475 from $\mathrm{An}_{60}$ to $\mathrm{An}_{51}$ and microcrysts from $\mathrm{An}_{53}$ to $\mathrm{An}_{46}$. Frequent xenocrysts $\mathrm{An}_{62-59}$ originated 
476 from a more mafic magma. The same features are depicted in the mugearite and benmoreite

477 evolutionary trend with $\mathrm{An}_{52-38}$ and $\mathrm{An}_{45-39}$ phenocrysts, $\mathrm{An}_{40-28}$ and $\mathrm{An}_{41-26}$ microcrysts, and $478 \mathrm{An}_{61-60}$ and $\mathrm{An}_{52-50}$ xenocrysys. In addition, K-rich microcrysts are discerned in mugearites $479\left(\mathrm{An}_{22-15}, \mathrm{Or}_{9-11}\right)$ and benmoreites $\left(\mathrm{An}_{25-14}, \mathrm{Or}_{9-16}\right)$. In trachytes, phenocrysts and microcrysts 480 are undistinguishable and consist of anorthoclase $\mathrm{Or}_{30-36}$.

481

482

483

484

485

486

487

488

489

490

491

492

493

494

495

496

497

498

499

500

501

502

503

504

505

506

507

508

509

\subsection{Petrographical features of Group 2 lavas}

The petrographical features of Group 2 lavas are shown in Table 3B. This group is limited to basanites, alkali basalts, hawaiites, mugearites, and rare trachy-phonolites, sharing similar features with equivalent lavas of Group 1, pending more abundant amphiboles and micas. A sub-holocrystalline, intergranular texture is observed in the ponded lavas and in the Mboriko plug-dome of the caldera. Mineral compositions are close to those of the Group 1 lavas.

\section{Olivine}

Olivine phenocrysts are zoned from 83.0 to 78.1. The microcrysts Fo 78.7-72.2 evolve from the phenocryst rim to slightly iron enriched composition. The phenocrysts of hawaiites Fo 78.7-70.5 exhibit the composition of the basalt microcrysts. Hawaiite microcrysts are iron enriched: 71.2-65.8. The mugearites show the same trend with the phenocrysts having Fo 77.1-64.4, and the microcrysts: Fo62.9-54.0. This is consistent with a continuous differentiation of a batch of magma involving drastic decrease of the $\mathrm{Mg}$ content as a result of olivine fractionation.

Xenocrysts are also recorded in basanites-alkali basalts (Fo 87.0-86.5) and inherited from a more primitive magma, hawaiites (Fo 85.0-82.5), inherited from the basanites magma, and mugearites (Fo 77.9-77.3), inherited from the hawaiite magma. As for Group 1, it is suspected that xenocrysts were removed from the walls of the main magma reservoir where olivines precipitated with decreasing temperature, causing differentiation of the residual magma.
Compositions of olivines are plotted in a $\mathrm{Fo} \%$ vs. $\mathrm{CaO}$ (wt.\%) diagram (Fig. 8B). Phenocrysts, microcrysts, as well as xenocrysts, crystallized from a related suite of magmas. In the Mg number vs. Fo diagram (Fig. 9), the olivine-liquid equilibrium temperature decreases from $1310^{\circ} \mathrm{C}$ for basanite to $1110^{\circ} \mathrm{C}$ for mugearite. The liquid temperature decreases from $1260^{\circ} \mathrm{C}$ to $1085^{\circ} \mathrm{C}$. 
510

511

512

513

514

515

516

517

518

519

520

521

522

523

524

525

526

527

528

529

530

531

532

533

534

535

536

537

538

539

540

541

542

543

\section{Magnetite and ilmenite}

The Group 2 magnetites share similar mineralogical features with those of Group 1. They consist of microphenocrysts, which are rare in basaltic lavas but common in evolved lavas, and abundant microcrysts. Compositions are similar to those of Group 1, except for the chromium content that may reach $12 \mathrm{wt} \%$ of $\mathrm{Cr}_{2} \mathrm{O}_{3}$ in basanite microphenocrysts. The mole content is dominated by magnetite, Mg-magnetite or Mg-ferrite, and ulvöspinel. The spinel component is limited by the $\mathrm{Al}$ amount. Exceeding $\mathrm{Mg}$ substitutes to $\mathrm{Fe}^{2+}$ in magnetite. From basanite and alkaline basalt to mugearite, spinel mole decreases and ulvöspinel increases.

Magnetite mole increases in hawaiite but decreases in mugearite. Mg-ferrite evolves inversely.

In Figure 10, magnetite compositions display positive correlation of $\mathrm{Ti} /(\mathrm{Ti}+\mathrm{Al}+\mathrm{Cr})$ and $\mathrm{Fe}^{2+} /\left(\mathrm{Fe}^{2+}+\mathrm{Mg}\right)$ ratios from basalt to mugearite due to decreasing $\mathrm{Al}, \mathrm{Mg}$, and also $\mathrm{Cr}$ contents in evolved magmas.

Ilmenites appear as microphenocrysts and microcrysts in basanites to mugearites. With evolving lava composition, they display a moderate enrichment in the hematite mole component $\left(\mathrm{X}^{\prime}{ }_{\text {ilm }}=0.96\right.$ to 0.94 and $\mathrm{Fe}^{3+} / \mathrm{Fe}^{2+}$ ratio $=0.09$ to 0.13$)$.

Rare coexisting magnetites and ilmenites have been analyzed in hawaiites. The $\log f_{\mathrm{O} 2}$ averages $-12.5 \pm 0.5$ slightly below the $\log f_{\mathrm{O} 2}(\mathrm{FMQ})$ value $\left(\Delta \log f_{\mathrm{O} 2}(\mathrm{FMQ})=-0.4\right)$. This agrees with the scarcity of early magnetites in mafic magmas.

\section{Pyroxene}

Group 2 pyroxenes have been analyzed in five basanites and olivine basalts, seven hawaiites, and four mugearites. As for Group 1 pyroxenes, xenocrysts are rare in basanites, frequent in hawaiites and abundant in mugearites (Fig. 11). In the Mg-Ca-Fet+Mn diagram (Fig. 14), a very limited trend is displayed from basanites phenocrysts to mugearite microcrysts with weak decreasing of $\mathrm{Mg}$ and increasing of $\mathrm{Fe}$ from phenocrysts and xenocrysts to microcrysts. As explained for the Group 1 pyroxenes before, xenocrysts, phenocrysts and microcrysts crystallized from magmas (Fig. 15A). They are only concerned with Ti-Tchermak, Ca-Tschermak and esseneite mole substitutions. However, the basanite phenocrysts show an unusual range of composition with either Mg-rich composition (type a) or apparent $\mathrm{Mg}$-depletion and $\mathrm{Ca}$-enrichment (type b). In the $\mathrm{Mg}$-Ca-Fe ternary diagram, the enrichment of Ca relative to $\mathrm{Mg}$ and $\mathrm{Fe}$ (the fassaitic feature) is a consequence of the contribution of the Tshermak moles to the pyroxene composition. The type b pyroxenes display higher contents in $\mathrm{Ti}, \mathrm{Al}$ and $\mathrm{Fe}^{3+}$. They plot in a Ti-enriched area in the $\mathrm{Fe}^{2+}$ vs. $\mathrm{Ti}$ 
544 diagram (Fig. 15B), where most of the pyroxenes define a common trend with $\mathrm{Fe}^{2+}$

545 enrichment from mafic phenocrysts and xenocrysts to evolved microcrysts. The high-Ti and

546 low-Ti pyroxenes are discriminated in the $\mathrm{Al}$ vs. Ti diagram (Fig. 15C). The $\mathrm{Ti}$ and $\mathrm{Fe}$

547 activities in the magma are controlled by the Ti-magnetite crystallization, depending on the

548 oxygen fugacity. In the mafic lavas, magnetites and pyroxenes crystallize in the same

549 thermobarometric range. In most of the cases for the vapor-rich alkaline magmas, magnetite

550 crystallizes first $\left(\right.$ high $\left.\mathrm{fO}_{2}\right)$. Then, the pyroxenes are moderately titaniferous. In the case of

551 poor magnetite crystallization $\left(\right.$ lower $\mathrm{fO}_{2}$ ), the pyroxenes are enriched in titanium. The

552 various types of pyroxenes are located at different flank eruptive centres. It is suggested that

553 these centres were supplied from different magma batches with varying oxygen fugacities.

554 One may conclude that the late parasitic volcanic activity was originated from separated 555 reservoirs.

556 According to the clinopyroxene-liquid thermobarometer of Putirka et al. (2003), calculated 557 pressure ranges from 12.1 to $12.8 \pm 1.7$ kbars. Assuming a crustal thickness of $33 \mathrm{~km}$ (Tokam 558 et al., 2010), the crystallization depth is located between 42 and $44 \mathrm{~km}$ in the upper mantle.

559 Iterative calculations give temperature values $20^{\circ} \mathrm{C}$ below the calculated liquid temperature

560 values, and 11.3 to $12.2 \mathrm{kbars}$, that is to say 39 to $42 \mathrm{~km}$ in depth. In both cases, the

561 crystallization depth is below the crystallization zone determined for the Group 1 pyroxenes.

562

563

564

565

566 abundant in the evolved rocks. Their composition evolves from edenite to kaersutite with $\mathrm{Mg} / \mathrm{Mg}+\mathrm{Fe}^{2+}$ ratios and $\mathrm{TiO}_{2}$ contents ranging from 0.74 to 0.79 and 2.6 to $3.5 \mathrm{wt}$. $\%$ for edenite and from 0.67 to 0.79 and 4.6 to 5.8 for kaersutite. They are frequently highly oxidized in basanites. $570 \mathrm{Mg} / \mathrm{Mg}+\mathrm{Fe}^{2+}<0.80 ; 4.4<\mathrm{TiO}_{2}$ wt $\left.\%<5.9\right)$.

571

572

573

574

575

576

577

\section{Amphibole and mica}

Amphiboles are common in Group 2 lavas from basanites to mugearites, in being more Biotites coexist with amphibole in displaying a Ti-rich phlogopite composition $(0.76<$

\section{Feldspar}

As for Group 1 lavas, phenocrysts and microcrysts show a common compositional trend from basanites to mugearites. Phenocrysts of basanites and alkaline basalts are $\mathrm{An}_{66-60}$ and microcrysts $\mathrm{An}_{62-52}$. A few rounded xenocrysts $\mathrm{An}_{43-39}$ originated from a more evolved magma are reported in some lavas. Plagioclases of hawaiites and mugearites are $\mathrm{An}_{60-50}$ and $\mathrm{An}_{55-43}$ for phenocrysts, and $\mathrm{An}_{55-45}$ and $\mathrm{An}_{47-32}$ for microcrysts, respectively. Again, rounded 
578 xenocrysts $\mathrm{An}_{28-22}$ originated from a more evolved unknown magma are analyzed in some

579 lavas. Additional K-rich microcrysts $\mathrm{An}_{11-6}$ and $\mathrm{Or}_{32-46}$ crystallized in the doleritic facies of 580 the caldera late extrusion.

581

582

\subsection{Petrographical features of the pre-Manengouba lavas}

583

584

The pre-Manengouba volcanic rocks are on one hand, the phonolites and trachytes of

585

Mounts Bakossi and Ekomane, and on the other hand, a hawaiite and a mugearite flow of the

586

Nlonako area (Fig. 7).

587

Phonolites and trachytes display a common trachytic texture with laths of sodic feldspars and microphenocrysts of pyroxenes.

589

The hawaiite is hyalo-microlitic porphyritic with $15 \%$ of phenocrysts and

590 microphenocrysts of abundant plagioclase, olivine $\mathrm{Fo}_{64-68}$, diopside, phlogopite, magnetite and rare ilmenite. The mineral composition is close to that of the Manengouba lavas except for the occurrence of phlogopite that is rare in Manengouba hawaiites. Magnetite is titaniferous and moderately aluminous and magnesian $\left(18.0<\mathrm{TiO}_{2}\right.$ wt. $\%<19.3 ; 2.9<\mathrm{Al}_{2} \mathrm{O}_{3}$ wt. $\%<4.5 ; 3.2<\mathrm{MgO}$ wt. $\left.\%<4.1 ; 0.56<\mathrm{X}_{\mathrm{Usp}}^{\prime}<0.58\right)$.

The mugearite is hyalo-microlitic porphyritic rich in phenocrysts of plagioclase in addition with xenocrysts of olivine $\mathrm{Fo}_{86-77}$ and phenocrysts and microphenocrysts of diopside $(41.9<$ $\mathrm{XMg} \%<44.0 ; 14.0<\mathrm{XFet}+\mathrm{Mn} \%<15.4 ; 41.3<\mathrm{XCa} \%<43.2)$, phlogopite, Ti-magnetite $\left(19.6<\mathrm{TiO}_{2}\right.$ wt. $\left.\%<22.4\right) .2 .3<\mathrm{Al}_{2} \mathrm{O}_{3}$ wt. $\%<4.2 ; 3.7<\mathrm{MgO}$ wt. $\%<4.7 ; 1.1 \mathrm{Cr}_{2} \mathrm{O}_{3}$ wt. $\%<$ $\left.1.4 ; 0.61<\mathrm{X}_{\text {Usp }}^{\prime}<0.67\right)$, and ilmenite $\left(\mathrm{X}_{\mathrm{Ilm}}^{\prime}=0.91 ; \mathrm{Fe}^{3+} / \mathrm{Fe}^{2+}=0.23\right)$. The xenocrystic olivine ranges from -11.1 to 9.9 with $\Delta \log f_{\mathrm{O} 2}(\mathrm{FMQ})=-0.1$.

602 According to the clinopyroxene-liquid thermobarometer of Putirka et al. (2003), calculated 603 pressure ranges from 6.0 to $5.2 \mathrm{kbars}$, locating the crystallization level in the lower to middle 604 crust.

605

606

\section{Geochemistry}

607

608

\subsection{Geochemical features}

609 
610

611

612

613

614

615

616

617

618

619

620

621

622

623

624

625

626

627

628

629

630

631

632

633

634

635

636

637

638

639

640

641

642

643

A total of 29 analyses have been carried out for the magmatic Group 1, 42 for the Group 2, and 2 for the Ekom rhyolite. Four analyses concern the western pre-Manengouba acidic lavas, and four the eastern pre-Manengouba mafic lavas.

The Group 1 lavas display a complete differentiation trend from basanite to trachyte. The Group 2 lavas evolve from basanite to trachy-phonolite. Both groups display similar trends on the $\mathrm{MgO}$ wt.\% vs. oxides covariation diagrams (Fig. 16A). Decrease of $\mathrm{MgO}$ and increase of all the oxides in the more mafic lavas are related to olivine fractionation. Below $8 \mathrm{MgO}$ wt.\%, additional fractionation of clinopyroxene in alkali basalt and hawaiite is evidenced by decreases of $\mathrm{CaO}$ and $\mathrm{FeO}$. The decreasing $\mathrm{TiO}_{2}$ in hawaiite indicates fractionation of Tibearing oxides. The sudden decrease of $\mathrm{Al}_{2} \mathrm{O}_{3}$ in mugearite points to plagioclase fractionation. Possible fractionation of apatite may have occurred in benmoreite according to $\mathrm{P}_{2} \mathrm{O}_{5}$ loss. In the minor element covariation diagrams (Fig. 16B), the compatible elements $\mathrm{Cr}$ and $\mathrm{Ni}$ display heavy depletion from mafic to evolved rocks due to $\mathrm{Mg}-\mathrm{Fe}$ phase fractionation. Vanadium decreases in hawaiites, like titanium, indicating an oxide fractionation. Strontium exhibits a wide range of contents betraying the heterogeneity of Group 2 lavas of the late magmatic activity. However, Sr-decreases in hawaiite and mugearite are linked to plagioclase fractionation. The incompatible elements $\mathrm{Rb}, \mathrm{Ba}, \mathrm{Ga}, \mathrm{Zr}, \mathrm{Hf}, \mathrm{Nb}, \mathrm{Ta}, \mathrm{Y}, \mathrm{Pb}, \mathrm{Th}, \mathrm{U}$, and the REE exhibit common enrichments from basanite to trachyte, while some trachytes and the rhyolite are depleted by volatile transfer. Again, variations in the $\mathrm{Zr}, \mathrm{Hf}, \mathrm{Nb}, \mathrm{Ta}$, and the light rare earth element contents in basalt and hawaiite indicate a somewhat heterogeneity of primitive magmas.

The incompatible element signatures are illustrated with the chondrite-normalized and MORB-normalized diagrams (Figs. 17 and 18). The stages 1 and 2 lavas display rare earth element (REE) enriched patterns with $(\mathrm{La} / \mathrm{Yb})_{\mathrm{N}}$ ratios ranging from 9.6 to 24.5 and 163 to 332 rare earth amounts. Compared to MORB, these lavas point to increasingly enriched trends from high field strength to large ion lithophile elements, except $\mathrm{Sr}$ and $\mathrm{K}$ which are poorly enriched. But the heavy rare earth elements are depleted indicating a different source than the MORB one.

The stage 3 evolved lavas are similarly enriched $\left(10.8<(\mathrm{La} / \mathrm{Yb})_{\mathrm{N}}<23.3\right)$, except the rhyolite $\left(3.0<(\mathrm{La} / \mathrm{Yb})_{\mathrm{N}}<7.3\right)$ with 259 to 589 rare earth element amounts. The trachytes exhibit significant negative $\mathrm{Eu}$ anomalies $\left(0.8<\mathrm{Eu} / \mathrm{Eu}^{*}<0.1\right)$. The MORB normalized patterns show higher amounts of incompatible trace elements compared to mafic lavas, and significant negative anomalies resulting from fractional crystallization that increases in importance from benmoreite to trachyte. The Ti and $\mathrm{P}$ negative anomalies are due to 
644 fractional crystallization of oxides and apatite, respectively. $\mathrm{Ba}, \mathrm{Sr}$, in addition with $\mathrm{Eu}$

645 negative anomalies in trachyte comply with feldspar fractionation.

646 The stage 4 lavas (Group 2) display the same patterns as the stages 1 and 2 lavas. From 647 basanite to trachy-phonolite, the $(\mathrm{La} / \mathrm{Yb})_{\mathrm{N}}$ ratios range from 9.5 to 25.6 , and rare earth 648 abundances from 117 to 379. They are poorly enriched in Sr and K, and depleted in the heavy

649 rare earth elements. The lava with the lowest enrichment in incompatible elements is an 650 olivine and pyroxene-rich basanite (CT110) of a thick flow that ponded inside the caldera in 651 form of a temporary lava lake. This relative depletion is due to olivine and pyroxene

652 cumulation. The basanite to trachy-phonolite evolved patterns are compatible with fractional 653 crystallization as shown by the major element covariation diagrams (Fig. 16). Most of the 654 mugearites exhibit moderate $\mathrm{P}$ and Ti negative anomalies denoting apatite and oxides 655 fractionation. A few mugearites have weak positive anomalies of $\mathrm{Ba}$ and Eu, compatible with 656 feldspar cumulation. The trachy-phonolite is enriched in incompatible elements but depleted 657 in $\mathrm{Eu}, \mathrm{Ba}, \mathrm{P}$, and Ti. These features denote fractional crystallization of feldspar, apatite and 658 oxides.

659 The pre-Manengouba mafic lavas share close geochemical compositions with the lavas of 660 Manengouba. The hawaiites show positive anomalies of Eu and Ba due to feldspar 661 accumulation. The trachytes and phonolites show signs of fractional crystallization of 662 feldspar, apatite and oxides as evidenced by negative anomalies of $\mathrm{Eu}, \mathrm{Ba}, \mathrm{P}$, and $\mathrm{Ti}$. In 663 addition, the phonolites are depleted in the middle rare earth elements (MREE) and Ta that 664 may suggest an amphibole fractionation because amphibole has a greater compatibility of the 665 MREE (Zack at al., 1997).

666 The Manengouba mugearites and benmoreites contain a few biotite and amphibole that 667 may have played in the differentiation processes. To test this effect, $\mathrm{Rb}, \mathrm{Ba}, \mathrm{K}$, and $\mathrm{Sr}$ 668 covariation diagrams have been drawn, as well as a $\mathrm{Ba} / \mathrm{Rb}$ vs. $\mathrm{Rb} / \mathrm{Sr}$ diagram as suggested by 669 Furman et al. (2006). The differentiation trends for these elements are dominated by the 670 feldspar fractionation. Indeed, the lithophile element variations indicate a limited role or no 671 role for biotite and amphibole. In return, $\mathrm{Th}$ and $\mathrm{Pb}$ contents in many trachytes attest for a 672 crustal contribution. Lower $\mathrm{Ce} / \mathrm{Pb}$ is typical of crustal assimilation. $\mathrm{A} \mathrm{Ce} / \mathrm{Pb}$ value lower then 67320 is commonly retained (Rogers et al., 1992; Furman et al., 2007). In the $\mathrm{Th} / \mathrm{Pb}$ vs. $\mathrm{Ce} / \mathrm{Pb}$ 674 diagram (Fig. 19), all the trachytes plot below this value, as well as the Bakossi phonolites. 675 
The mafic lava compositions are used to determine the parental magma composition and the mantle source characteristics, excluding cumulate facies. The closest rocks to primary mantle melts are CT46 and EB20 for the Manengouba main cone building (Stages 1 and 2, magmatic Group 1) and for the late activity (Stage 4; magmatic Group 2) owing to their $\mathrm{MgO}$ and Ni contents (Fig. 20). CT46 is a basal thick flow of the early shield volcano cropping out at the lower southern flank. EB20 is an intra-caldera flow that filled the caldera basin before the ultimate explosive maar activity. We retain the mafic lavas of magmatic Group 1 (5 analyses) and of Group 2 restricted to $\mathrm{MgO}$ greater than 6 wt.\% (15 analyses). Two neighbouring olivine fractionation trends can be defined from the partial melting area drawn after Class et al. (1994). The primary melt composition averages 9 to $10 \mathrm{wt} . \%$ of $\mathrm{MgO}$ and 250 to $290 \mathrm{ppm}$ of Ni.

The MORB normalized trace element diagram of the selected mafic lavas show that the Manengouba profiles are identical to that of the average OIB of Sun and McDonough (1989) (Fig. 21). A similar enriched mantle source can be assumed, as shown by the Ta/Yb vs. $\mathrm{Th} / \mathrm{Yb}$ diagram (Fig. 22A). However, distinct $\mathrm{Zr} / \mathrm{Hf}$ and $\mathrm{Nb} / \mathrm{Ta}$ ratios (Fig. 22B) prove that the sub-Manengouba mantle source is different of that of OIBs, and also of MORBs and continental basalts. This source is suspected to have high $\mathrm{Zr} / \mathrm{Hf}$ ratio of 46.2 and low $\mathrm{Nb} / \mathrm{Ta}$ ratio of 13.75 averaging the CT46 and EB20 values. Considering the set of mafic lavas, $\mathrm{Nb} / \mathrm{Ta}$ remains constant with variable $\mathrm{Zr} / \mathrm{Hf}$, a feature of OIB and MORB fields that is usually explained by pyroxene fractionation (Pfänder et al., 2007 and 2012). However, the petrographical relationships show that the $\mathrm{Zr} / \mathrm{Hf}$ ratio decreases with $\mathrm{Zr}$ from mafic to evolved lavas. Such a trend cannot be explained by pyroxene fractionation. Similar high $\mathrm{Zr} / \mathrm{Hf}$ ratios are known from the eastern and western branches of the East African rift, but with high $\mathrm{Nb} / \mathrm{Ta}$ ratios as in the Kenya rift (Rogers et al., 2006). Nevertheless, lavas of the Virunga area, north of the Lake Kivu, display $\mathrm{Nb} / \mathrm{Ta}$ ratios close to those of the Manengouba, as well as high Zr/Hf ratios (Rogers et al., 1992, 1998; Platz et al., 2004; Chakrabarti et al., 2009). The $\mathrm{Zr} / \mathrm{Hf}$ trend can be due to enrichment of the source region by metasomatic fluid as suggested by Dupuy et al. (1992) or to infiltration of carbonatite-rich fluids according to Rudnick et al. (1993).

The rare earth element abundances and ratios are commonly used to constrain the mantle source characteristics. The relative heavy rare earth element depletion with a $(\mathrm{Tb} / \mathrm{Yb})_{\mathrm{N}}$ ratio lower than 1.8 is indicative of a garnet-bearing source at the melting zone (e.g. Rooney et al., 2010). The higher ratio for CT46 (23.48) compare to EB20 (2.17) indicates a more amount of garnet in the source that must be deeper. The same result is given by the $(\mathrm{Dy} / \mathrm{Yb})_{\mathrm{N}}$ ratio 
712 compared to the $\mathrm{La} / \mathrm{Yb}_{\mathrm{N}}$ ratio used by Rogers et al. (2006) to calculate the garnet content of 713 the melting primitive mantle. In that case, the garnet content is $8 \%$ for CT46 and $4 \%$ for 714 EB20. If the source is enriched, contents are slightly lowered. Mineral composition and 715 degree of partial melting can be approached with $\mathrm{La} / \mathrm{Sm}$ and $\mathrm{Sm} / \mathrm{Yb}$ values. On the one hand, 716 the $\mathrm{La} / \mathrm{Sm}$ ratio is a function of the degree of melting and provides information on the source 717 chemical composition. On the other hand, the Sm/La ratio discriminates the spinel or garnet718 bearing source, and provides an estimation of the degree of melting once the $\mathrm{La} / \mathrm{Sm}$ ratio is 719 defined. In the La vs. $\mathrm{La} / \mathrm{Sm}$ and $\mathrm{La} / \mathrm{Sm}$ vs. Sm/Yb diagrams (Fig. 23), melt curves are drawn 720 for spinel-lherzolite, garnet-lherzolite, and a 50:50 mixture of spinel- and garnet-lherzolite. 721 Modal compositions of spinel-lherzolite (olivine 53\%, OPX 27\%, CPX 17\%, spinel 3\%) and 722 garnet-lherzolite (olivine 60\%, OPX 20\%, CPX 10\%, garnet 10\%) are after Kinzler (1997) 723 and Walter (1998). Mineral/melt partition coefficients for basaltic liquids are after the compilation of Rollinson (1993). The mantle array is defined by the depleted MORB mantle (DMM composition from Salters and Stracke, 2004) and primitive mantle (PM after Sun and McDonough, 1989) trend. In the La vs. La/Sm diagram (Fig. 23A), the mafic lavas plot in the melting trends between $2 \%$ and $5 \%$ of partial melting. The trends deal with an enriched source and a $\mathrm{La} / \mathrm{Sm}$ ratio value between 2 and 2.5. A more precise composition of the source is calculated by the inversion method. However, we know the precision of such calculation is

730 illusive whatever the used formulae and the batch melting scenarios, because of the

731 uncertainty of the bulk partition coefficients that highly control the results (notwithstanding 732 the heterogeneity of the source). In the $\mathrm{La} / \mathrm{Sm}$ vs. Sm/Yb diagram (Fig. 23B), the lavas plot 733 slightly above (CT46) or close (EB20) to the 50:50 spinel-garnet lherzolite melting trend.

734 Partial melting degrees average 3\% for CT46 and 6\% for EB20. On the base of the estimated 735 enriched source composition, the garnet content of the source could be 7\% for CT46 and 3\% 736 for EB20 according the $(\mathrm{Dy} / \mathrm{Yb})_{\mathrm{N}}$ ratio compared to the $\mathrm{La} / \mathrm{Yb}_{\mathrm{N}}$ ratio (Rogers et al., 2006). 737 Assuming a 6 to 8 times enrichment of chondritic abundances suggested by the La/Sm and $738 \mathrm{Sm} / \mathrm{Yb}$ ratios and a La value averaging 2.2, the melting degrees are calculated on the base of 739 the above indicated data. Unrealistic values were obtained due to excess garnet in the source. 740 A second calculation was done with the garnet peridotite composition and bulk partition 741 coefficients of Salters and Longhi (1999), and Salters et al. (2002). Partial melting degrees of $7423 \%$ for CT46 and of $6 \%$ for EB20 agree with the $\mathrm{La} / \mathrm{Sm}-\mathrm{Sm} / \mathrm{Yb}$ diagram.

743 It can be concluded that melting took place in the spinel to garnet transition zone located at 74470 to $90 \mathrm{~km}$ and around $25 \mathrm{~kb}$ at the melt temperature values (O'Neill, 1981; Schilling et al. 745 2005). The less abundant garnet and the higher partial melting degree in the late and parasitic 
746

747

748

749

750

751

752

753

754

755

756

757

758

759

760

761

762

763

764

765

766

767

768

769

770

771

772

773

774

775

776

777

778

779

volcanic activity (EB20, Stage 4) indicate uprising of the melting column to the upper part of transition zone. It has been noted that the magmatic signature is sodic (Fig. 7) and poor in potassium. $\mathrm{Rb}$ is moderately enriched and the $\mathrm{Ba} / \mathrm{Rb}$ and $\mathrm{Rb} / \mathrm{Sr}$ ratios are low. These chemical features are compatible with an amphibole-bearing source rather than with a mica-bearing source. Limit of the stability fields of amphibole and phlogopite locates around 25 to $30 \mathrm{~kb}$ in the lithospheric mantle (e.g. Class and Goldstein, 1997). It is consistent with the location of the Manengouba magma source in the spinel-garnet transition zone and in the amphibole field. The existence of an amphibole-bearing upper mantle beneath the CVL is supported by the sampling of amphibole-spinel-garnet ultramafic xenoliths in volcanoes of Ngaoundéré, Lake Nyos, Oku, and Mount Cameroon (Lee et al. 1996; Temdjim et al., 2004; Matsukage and Oya, 2010; Temdjim, 2012). After Marzoli et al. (2000), trace element patterns agree with an amphibole-bearing source for Sr-rich mafic rocks of the Bambouto volcano. Moreover, an amphibole-bearing lherzolite composition is advocated by Yokoyama et al (2007) for the lithospheric mantle beneath Mt Cameroon on the base of $\mathrm{U}$-series disequilibria relationships. It is straightforward to postulate that the same lithospheric mantle locates beneath $\mathrm{Mt}$ Manengouba.

\section{3. Isotopic data}

A total of nine samples of Manengouba have been analyzed by Halliday et al. $(1988 ; 1990)$ for $\mathrm{Sr}, \mathrm{Nd}$, and $\mathrm{Pb}$ isotope ratios. Most of these samples are basaltic lavas from the flank cones. One basalt belongs to the old shield. The ratio variations between old and recent lavas are in the range of the analytical reproducibility. In addition to these data, we analyzed seven samples of Manengouba including the Ekom rhyolite and the trachy-phonolite of the late north-western flank activity, and three samples of the north-western Essom trachyte, the Bakossi phonolite, and the eastern basaltic substratum (Table 6). A representative mafic lava of Manengouba, the rhyolite, the trachy-phonolite and the Essom trachyte have been selected for lead isotope analyses.

In the Manengouba lavas, initial ${ }^{87} \mathrm{Sr} /{ }^{86} \mathrm{Sr}$ ratios display a restricted range from 0.7030 to 0.7032 with low radiogenic Sr values close to the Enriched Depleted MORB Mantle in Figure 24A (E-DMM of Workman and Hart, 2005). Initial ${ }^{143} \mathrm{Nd} /{ }^{144} \mathrm{Nd}$ ratios expressed as $\varepsilon N d$ are from +4.4 to +6.8 , the lowest value pertaining to the trachy-phonolite. The values of the late Miocene hawaiite of the substratum are close to those of the Manengouba and may have originated from similar source. As it is common, trachyte, phonolite, and rhyolite are 
780 enriched in radiogenic Sr resulting from crustal assimilation as shown by the chemical data.

781 In return, such process has not affected the trachy-phonolite that simply derived from mafic

782 parent by fractional crystallization. The $\mathrm{Pb}$ isotopic compositions of Manengouba are

783 radiogenic with $19.6<{ }^{206} \mathrm{~Pb} /{ }^{204} \mathrm{~Pb}<20.2,15.6<{ }^{207} \mathrm{~Pb} /{ }^{204} \mathrm{~Pb}<15.7$, and $39.3<{ }^{208} \mathrm{~Pb} /{ }^{204} \mathrm{~Pb}<$

784 39.9. They straddle to the FOZO component redefined by Stracke et al. (2005) and plot near

785 the NHRL (Northern Hemisphere Reference Line at $1.77 \mathrm{Ga}$; Hart, 1984) with a Th/U ratio

786 averaging 4 (Fig. 24B and C). The Ekom rhyolite and the Essom trachyte, thought to be

787 contaminated by continental crustal material are less radiogenic. It should be noted that the

788 rhyolite was fractionated in $\mathrm{U}$ and $\mathrm{Pb}(\mathrm{Th} / \mathrm{U}=21)$.

789 The Manengouba shares same geochemical and isotopic features with all the Cenozoic

790 volcanoes of the Cameroon Volcanic Line (CVL), and particularly the high ${ }^{208} \mathrm{~Pb} /{ }^{204} \mathrm{~Pb}$ ratio

791 commonly related to the HIMU component. Along the CVL, one distinctive isotopic feature

792 is reported with slightly higher ${ }^{206} \mathrm{~Pb} /{ }^{204} \mathrm{~Pb}$ ratio for the continental-ocean boundary (cob)

793 volcanoes (Mount Cameroon, Etinde, Bioko) compared to the continental sector and the

794 oceanic sector (Halliday et al., 1988). The Manengouba isotope values are similar to those of

795 the continental part.

796

797

\subsection{Search for the source components}

798

799

800

The Cameroon Volcanic Line is characterized by depleted values of the $\mathrm{Sr}$ and $\mathrm{Nd}$ isotopic ratios with $\mathrm{Pb}$ isotopic radiogenic enrichments. There are no prominent geochemical

801 discrepancies between the recent lavas of both the continental and oceanic sectors. On these

802 bases, it was suggested that the lavas have been derived from sub-lithospheric sources which

803 were contaminated by melts of an (HIMU) enriched fossil plume head emplaced during

804 continental breakup in the present Gulf of Guinea area (Halliday et al., 1990; Lee et al., 1994).

805 Alternatively, the lead isotope peculiarities may be explained by contamination of primary

806 asthenospheric melts by melting of sub-continental mantle hosted the FOZO component

807 (Rankenburg et al., 2005). For addressing these models to the Manengouba magmatic sources,

808 we collected the $\mathrm{Sr}, \mathrm{Nd}$, and $\mathrm{Pb}$ isotopic values of the CVL from Halliday et al. $(1988 ; 1990)$,

809 Lee et al. (1994), Marzoli et al. (2000), Rankenburg et al. (2005), Yokoyama et al. (2007),

810 Nkouandou et al. (2008), Nkouathio et al. (2008), Wandji et al. (2009), Mbassa et al. (2012)

811 and Kamgang et al. (2013). We limited the data set to mafic lavas and recalculated the initial

812 ratios. Plotted results are outlined in ${ }^{87} \mathrm{Sr} /{ }^{86} \mathrm{Sr}$ vs. ${ }^{143} \mathrm{Nd} /{ }^{144} \mathrm{Nd},{ }^{206} \mathrm{~Pb} /{ }^{204} \mathrm{~Pb}$ vs. ${ }^{207} \mathrm{~Pb} /{ }^{204} \mathrm{~Pb}$, and

$813{ }^{206} \mathrm{~Pb} /{ }^{204} \mathrm{~Pb}$ vs. ${ }^{208} \mathrm{~Pb} /{ }^{204} \mathrm{~Pb}$ diagrams (Fig. 24A, B and $\mathrm{C}$ ). 
814 Lavas of the CVL are distributed in six groups bearing on distinct isotopic features (Fig.

815 1): 1) Biu and Mandara lavas in the northern end display both the highest depleted and the

816 highly radiogenic terms. They also show a wide compositional range to enriched and less

817 radiogenic terms. Rankenburg et al. (2005) explain these features with two contamination

818 processes of the primary magmas: addition of an "enriched" (they mean "radiogenic") sub-

819 continental lithospheric melts and addition of bulk continental crust. 2) Ngaoundéré lavas in

820 the north-eastern faulted branch are moderately enriched and moderately radiogenic with an

821 enrichment trend. 3) Lavas of the middle continental sector of the CVL (Oku, Bamenda,

822 Bambouto, Manengouba and Tombel) share similar moderately enriched and moderately

823 radiogenic isotope composition, but with a significant enrichment trend suggesting an EM1

824 contribution according to $\mathrm{Sr} / \mathrm{Nd}$ and lead isotope covariation diagrams (Fig. 24). 4) Towards

825 the continent-ocean boundary (COB), lavas of Mount Cameroon, Etinde, and Bioko Island are

826 characterized by high radiogenic lead isotope ratios that are due to young fractionation in

$827 \mathrm{U} / \mathrm{Pb}$ within the upper mantle according to correlatives with $\mathrm{Sr}, \mathrm{Nd}, \mathrm{Pb}$, and $\mathrm{Hf}$ isotopic

828 values (Ballentine et al., 1997). They are fairly enriched with low Nd isotopic ratios 5) At the

829 islands of Principe and São Tomé, lavas are quite similar with highly to moderately

830 radiogenic lead isotopes and significantly depleted terms. 6) The Pagalu Island lavas point out

831 unradiogenic lead ratios and somewhat enriched terms.

832 The salient isotopic features are best discriminated in the $\mathrm{Sr} v \mathrm{vs.}{ }^{208} \mathrm{~Pb} /{ }^{204} \mathrm{~Pb}$ diagram (Fig.

833 24D). The data fields are explained by varying contribution of three components. First, two

834 components: a depleted component (DC) and a radiogenic component (RC) define the

835 primary magmas, because they are prominent in the most primitive lavas. DC and RC

836 resemble the 'A' and 'B' components of Rankenburg et al. (2005). Then, the different

837 primary magmas evolve along orthogonal paths owing to increasing contribution of an

838 enriched component (EC) that could be the 'CC' component of Rankenburg et al. (2005).

839 The geochemical data reveal that there are no doubts that the depleted component

840 originated from asthenospheric upwelling that occurred all along the CVL as shown by swell

841 elevation related to thermal thinning (Poudjon-Djomani et al., 1995, 1997; Meyers et al.,

842 1998). The radiogenic component was suspected to belong to a plume head. One main

843 plume (St Helena type) or several small plumes (Halliday et al., 1988; Lee et al. 1994, 1996)

844 have fed the upper mantle in the past and contaminated the magmatic sources with the HIMU

845 component. However, the highest radiogenic composition of the cognate magmatic

846 megacrysts reflecting the source composition may be representative of the radiogenic end-

847 member after Rankenburg et al. (2005). This end-member is more enriched than the HIMU 
848 end-member (higher $\mathrm{Sr}$ ratio and lower $\mathrm{Nd}$ ratio) and is close to the richest $\mathrm{Nd}$ and $\mathrm{Pb}$ ratio

849 domain of the FOZO compositional field (Stracke et al., 2005). In the African plate Cenozoic

850 volcanism, FOZO is ubiquitous in the continental part: Hoggar-Aïr, Darfur, Ethiopia, Kenya, 851 and Tanzania (Paslick et al., 1995; Franz et al., 1999; Aït-Hamou et al., 2000; Rogers et al.,

852 2000; Kieffer et al., 2004; Furman et al., 2006; Pik et al., 2006) as well as in the oceanic part:

853 Canary, Madeira, and Cape Verde (Gerlach et al., 1988; Hoernle et al., 1991; Halliday et al.,

854 1992; Millet et al., 2008). The continental sectors are located in the Mesoproterozoic and

855 Neoproterozoic mobile belts where many ocean plate subduction and collision processes have

856 taken place. It can thus be inferred that the continental lithosphere, unlike the oceanic

857 lithosphere, registered multiple metasomatic events and not only a single Mesozoic

858 enrichment from a hypothetical mantle plume. Consequently, we assume that the radiogenic

859 component is a common feature of the African continental lithosphere particularly in the Pan-

860 African belts. This radiogenic orogenic-related source is more realistic than the plume source

861 unless to invoke numbers of plume and unsustainable plume tracks. No plume trail can be

862 evidenced below the CVL (Pasyanos and Nyblade, 2007). Late Pliocene to present day

863 volcanic activities emplaced simultaneously all along the CVL, from Biu to the middle

864 continental sector, the Mount Cameroon, and the Pagalu Island (Fitton and Dunlop, 1985: Lee

865 et al., 1994; Kagou Dongmo et al., 2010).

866 The enriched component resembles the ' $\mathrm{CC}$ ' component of Rankenburg et al. (2005)

867 deriving either from the sub-continental lithospheric mantle (SCLM) or the continental crust, 868 both being characterized by high $\mathrm{Sr}$ isotope ratio and low $\mathrm{Nd}$ and $\mathrm{Pb}$ isotope ratios (Fig. 24).

869 On the base of osmium isotope values, Rankenburg et al. (2005) promote the contamination

870 with continental crust for Biu lavas. Similar isotopic trends are shown by mafic lavas of the

871 middle continental CVL, namely in the Bambouto and Bamenda volcanoes (Nkouathio et al.,

872 2008; Kamgang et al., 2013). These volcanoes and the Manengouba have produced abundant

873 evolved lavas, phonolites, trachytes, and rhyolites. These acidic lavas display geochemical

874 evidences of crustal contamination, as shown for the Manengouba trachytes (this work, Fig.

875 19). In return, no clear geochemical witnesses of crustal assimilation are seen in the mafic

876 lavas. Except for the Os isotope ratio (after Rankenburg et al., 2005), the commonly used

877 isotope ratios $(\mathrm{Sr}, \mathrm{Nd}, \mathrm{Pb})$ are unable do discriminate alone between the crust and the

878 enriched mantle contributions. In the lack of crustal-related geochemical arguments, we

879 support the hypothesis that enriched trends to EC in mafic lavas are due to the contribution

880 either of an EM1-like inherent component of the sub-continental lithosphere or to any recent

881 enrichment linked to pre-rifting processes. Indeed, clear evidences of sub-continental 
882 lithosphere enrichment are given by the numerous Cretaceous to Eocene alkaline volcano-

883 plutonic complexes distributed all along the CVL from the Atlantic coast to the Lake Chad

884 (Déruelle et al., 1991; Vicat et al., 2002) and emplaced before the Miocene to present-day 885 volcanoes.

886 A latent question is how the lavas of the oceanic portion of the CVL can be so enriched in 887 continental lithosphere source component if both the radiogenic and the enriched components 888 (RC and EC) belong to the sub-continental lithospheric mantle? The oceanic localization 889 would favour asthenospheric origin of the source components. Indeed, the Pagalu lavas are 890 unradiogenic but significantly enriched (Fig. 24D). Many authors have invoked the 891 entrainment of delaminated continental fragments in the oceanic domain during the 892 continental breakup (e.g. Rankenburg et al., 2005). First, we must specify that the CVL 893 oceanic volcanoes straddle NE-SW fracture zones in the continuation the continental fault 894 network predating the breakup (Meyers et al., 1998). Second, these faults have fed a 895 continental margin volcanic activity: the Pointe Gombé volcano and the Banc du Loiret lava 896 plateau (Cornen et al., 1993). This activity was contemporaneous with the early activity of the 897 São Tomé and Pagalu volcanoes and shares the same petrographical, chemical, and isotopic 898 composition (Cornen et al., 1993). Third, these faults are associated with post-Pan-African 899 late Neoproterozoic intrusions of alkaline syenites and carbonatites that give evidences of 900 metasomatic enrichment of the sub-continental mantle. The São Tomé volcano straddles the 901 Kribi fracture zone that joints the on-land northern Kribi Fault. The Pagalu volcano straddles 902 the Fang fracture zone that extends the Kribi Fault. The Fang fracture zone has fed the Pointe 903 Gombé and Banc du Loiret volcanics in the time of the Pagalu volcano building. The Kribi 904 Fault is linked to the Kribi alkaline syenite recently investigated and dated at $590 \mathrm{Ma}$ (Nsifa et 905 al., 2013). Giving all these consistent volcano-tectonic relationships, there is no doubt that 906 magmas of the CVL oceanic volcanoes merely originated from the metasomatized sub907 continental mantle. The source of Pagalu is limited to DC+EC (Fig. 24D) and is located in the

908 Congo Craton margin lithospheric mantle and outside the Pan-African realm that may explain 909 its unradiogenic composition.

910

911 6. Conclusion

912

913 The Mount Manengouba is a great volcano of the middle continental sector of the 914 Cameroon Volcanic Line (CVL). It culminates at $2411 \mathrm{~m}$ and covers $500 \mathrm{~km}^{2}$. It emplaced in 
915 a graben between two $\mathrm{N} 30^{\circ} \mathrm{E}$ trending normal faults. It straddles a $\mathrm{N} 50^{\circ} \mathrm{E}$ fracture zone 916 suggesting a right-lateral transtensional setting.

917 New mapping of the volcanic formations led to distinguish four chronological units from 918 the early shield volcano to the late flank lavas. The volume of the volcano is calculated at 320 $919 \mathrm{~km}^{3} \pm 5 \%$. The final flank activity volume is weak and estimated between 1.5 to $2 \mathrm{~km}^{3}$. The 920 four chronological stages dated by 5 published $\mathrm{K} / \mathrm{Ar}$ ages and 11 new $\mathrm{K} / \mathrm{Ar}$ and ${ }^{40} \mathrm{Ar} /{ }^{39} \mathrm{Ar}$ 921 measurements are as follow: 1) piling-up of the early Manengouba shield volcano between 9221.55 and $0.94 \mathrm{Ma}, 2)$ building of the Eboga stratovolcano between 0.94 and $0.89 \mathrm{Ma}, 3$ ) 923 caldera collapse and acidic Elengoum extrusions between 0.89 and $0.70 \mathrm{Ma}$, and 4) intra924 caldera and flank activity between 0.45 and $0.11 \mathrm{Ma}$. New K/Ar ages are also provided for 925 pre-Manengouba volcanic activities: $13.56 \mathrm{Ma}$ and $7.55 \mathrm{Ma}$ for a trachyte and a phonolite of 926 the western border, and 9.37 Ma for a hawaiite of the south-eastern substratum of the 927 Manengouba shield.

928 The Eboga caldera belongs to the Krakatoan or plate-piston type and resulted from a single 929 collapse. It is classified in the type-Ms and type-L of Geyer and Marti (2008).

930 The volcanic rocks are attributed to two magmatic outputs. The first and main magma 931 generation produced the shield volcano, the stratovolcano, and the syn- to post-caldera 932 extrusions, displaying a complete series from basanites to trachytes (magmatic Group 1). The 933 second magma production is limited to the late intra-caldera and flank activity evolving to 934 basanites to trachy-phonolite (magmatic Group 2). Olivine and pyroxene thermobarometers 935 locate the magmatic reservoir between 37 and $39 \mathrm{~km}$ in the upper mantle for the Group 1 936 lavas, and between 42 and $44 \mathrm{~km}$ for the Group 2 lavas. Similar depth, 35 to $44 \mathrm{~km}$, has been 937 obtained with the same method for the magma chamber of basanites of Mount Cameroon by 938 Wandji et al. (2009). Trachytes were generated in a secondary crustal reservoir because of the 939 large gap in the pyroxene composition. Magmatic series evolve with medium to low pressure 940 fractional crystallization of olivine, pyroxene, oxides, feldspar, and apatite. Significant crustal 941 assimilation is evidenced in trachytes. The parental magma composition is estimated close to 942 the average OIB composition. But, distinct $\mathrm{Zr} / \mathrm{Hf}$ and $\mathrm{Nb} / \mathrm{Ta}$ ratios prove that the magma 943 source registered a distinct metasomatic enrichment event. The magma of the main volcano 944 was generated with 3 to $6 \%$ of partial melting of a moderately enriched source (6 to 8 times 945 enrichment of chondrite abundances) containing 3 to $7 \%$ of garnet. Melting of the 946 Manengouba source took place in the spinel to garnet transition zone located at 70 to $90 \mathrm{~km}$ 947 and around $25 \mathrm{~kb}$ at the melt temperature values. The magma of the late flank activity resulted 948 from a slightly higher partial melting from a less garnet-rich source that indicates uprising of 
949 the melting column to the upper part of transition zone. The low $\mathrm{Rb}$ contents and low $\mathrm{Ba} / \mathrm{Rb}$

950 and $\mathrm{Rb} / \mathrm{Sr}$ ratios are compatible with an amphibole-bearing source.

951 Some $\mathrm{Sr}, \mathrm{Nd}$, and $\mathrm{Pb}$ isotope new data of the Manengouba rocks and neighbouring lavas 952 complete the data of Halliday et al. $(1988,1990)$. They comply with those of the middle 953 continental sector of the CVL. Sr and Nd isotope values plot near the enriched depleted 954 MORB mantle source with a moderate enrichment. $\mathrm{Pb}$ isotope values are somewhat 955 radiogenic in plotting in the FOZO compositional field, close to the NHRL, and show a short 956 enrichment trend. The evolved lavas are unradiogenic and registered crustal assimilation.

957 Review of the isotope data of mafic lavas of the whole CVL led to discriminate three source 958 components: a depleted component related to the asthenospheric upwelling, a radiogenic 959 component that we attributed to the lithosphere of the Neoproterozoic mobile belt 960 contaminated during orogenic events, and an enriched component or the lithosphere possibly 961 related to pre-rifting magmatic processes linked to the Cretaceous to Eocene intrusions of 962 alkaline volcano-plutonic complexes distributed all along the CVL.

963

\section{Aknowledgements}

965 This work has been supported by the SCAC (Service de Coopération et d'Action Culturelle 966 de la France au Cameroun) and EGIDE (Centre français pour l'accueil et les échanges 967 internationaux) of the French Government. Mineral analyses are indebted to the Institut des 968 Sciences de la Terre of the University and CNRS of Orléans (France), and to the Faculty of 969 Sciences of the University of Orsay (France). Special thanks are due to Daniel Demaiffe of 970 the Laboratory of isotope geochemistry of the Open University of Bruxelles, Belgium, for 971 providing the $\mathrm{Sr}-, \mathrm{Nd}-$, and $\mathrm{Pb}$-measurements. We are grateful to two anonymous reviewers 972 who provided useful critiques of this contribution.

973 This paper is dedicated to Pr. Pierre Wandji who has leaved our world in April 2014. Pierre 974 Wandji managed many volcanological studies of the Cameroon Line and was the director of 975 Armand Kagou Dongmo, Pulchérie Chakam Tagheu and David Nkouathio.

\section{References}

980 analogue models compared to natural calderas. Earth-Science Reviews 85, 125-160.

981 Aït-Hamou, F., Dautria, J.M., Cantagrel, J.M., Dostal, J., Briqueu, L., 2000. Nouvelles

982 données géochronologiques et isotopiques sur le volcanisme cénozoïque de l'Ahaggar 
983

984

985

986

987

988

989

990

991

992

993

994

995

996

997

998

999

1000

1001

1002

1003

1004

1005

1006

1007

1008

1009

1010

1011

1012

1013

1014

1015

(Sahara algérien) : des arguments en faveur de l'existence d'un panache. C. R. Acad. Sci. Paris, Sciences de la Terre et des planètes, 330, 829-836.

Andersen, D.J., Lindsley, D.H., 1988. Internally consistent solution models for Fe-Mg-Mn-Ti oxides: Fe-Ti oxides. Am. Mineralogist 73, 714-726.

Ballentine, C.J., Lee, D.-C., Halliday, A.N., 1997. Hafnium isotopic studies of the Cameroon line and new HIMU paradoxes. Chemical Geology 139, 111-124

Cantagrel, J.-M., Jamond, C., Lasserre, M., 1978. Le magmatisme alcalin de la "Ligne du Cameroun" au Tertiaire inférieur : données géochronologiques K/Ar. C. R. Som. Soc. Géol. France, 6, 300-303.

Chakam Tagheu, P.J., 2006. Le volcanisme quaternaire des régions du stratovolcano Manengouba (Ligne du Cameroun). Thèse de $3^{\text {ème }}$ cycle Univ. Yaoundé I, Cameroon, $155 \mathrm{p}$.

Chakrabarti, R., Basu, A.R., Santo, A.P., Tedesco, D., Vaselli, O., 2009. Isotopic and geochemical evidence for a heterogeneous mantle plume origin of the Virunga volcanics, Western rift, East African Rift system. Chemical Geology 259, 273-289.

Cole, J.W., Milner, D.M., Spinks, K.D., 2005. Calderas and caldera structures: a review. Earth-Science Reviews 69, 1-26.

Class, C., Altherr, R., Volker, F., Eberz, G., McCulloch, M.T., 1994. Geochemistry of Pliocene to Quaternary alkali basalts from the Huri Hills, northern Kenya. Chemical Geology 113, 1-22.

Class, C., Goldstein, S.L., 1997. Plume-lithosphere interactions in the ocean basins: constraints from the source mineralogy. Earth Planet. Sci. Lett. 150, 245-260.

Cornen, G., Bellon, H., Joron, J.-L., 1993. Le volcan de Pointe Gombé (Gabon) et ses relations avec le Golfe de Guinée. C. R. Acad. Sci. Paris, t. 317, Série II, 919-926.

Déruelle, B., Moreau, C., Nkoumbou, C., Kambou, R., Lissom, J., Njongfang, E., Ghogomu, R.T., Nono, A., 1991. The Cameroon Line: a review. In: Kampunzu, A.B., Lubala, R.T. (Eds.), Magmatism in extensional structural settings. The Phanerozoic African Plate. Springer, Berlin, pp. 274-327.

Déruelle, B., Bardintzeff, J.-M., Cheminée, J.-L., Ngounouno, I., Lissom, J., Nkoumbou, C., Etame, J., Hell, J.V., Tanyileke, G., N'ni, J., Ateba, B., Ntepe, N., Nono, A., Wandji, P., Fosso, J., Nkouathio, D.G., 2000. Eruptions simultanées de basalte alcalin et de hawaiite au mont Cameroun (28 mars-17 avril 1999). C.R. Acad. Sci. Paris, Sér IIa 331, 8, 525 531. 
1016 Déruelle, B., Ngounouno, I., Demaiffe, D., 2007. The «Cameroon Hot Line » (CHL): A

1017 unique example of active alkaline intraplate structure in both oceanic and continental

1018

1019

1020

1021

1022

1023

1024

1025

1026

1027

1028

1029

1030

1031

1032

1033

1034

1035

1036

1037

1038

1039

1040

1041

1042

1043

1044

1045 lithospheres. C.R. Geoscience 339, 589-600.

Dunlop, H.M., 1983. Strontium isotope geochemistry and potassium-argon studies on volcanic rocks from the Cameroon line, West Africa. $\mathrm{PhD}$. thesis Univ. Edinburgh, Great Britain, 347p.

Dupuy, C., Liotard, J.M., Dostal, J., 1992. Zr/Hf fractionation in intraplate basaltic rocks: Carbonate metasomatism in the mantle source. Geochim. Cosmichim. Acta 56, 2417-2423.

Fitton, J.G., Dunlop, H.M., 1985. The Cameroon line, West Africa, and its bearing on the origin of oceanic and continental alkali basalt. Earth Planet. Sci. Lett. 72, 23-38.

Franz, G., Steiner, G., Volker, F., Pudlo, D., Hammerschmidt, K., 1999. Plume related alkaline magmatism in central Africa-the Meidob Hills (W Sudan). Chemical Geology $157,27-47$.

Furman, T., Graham, D., 1999. Erosion of lithospheric mantle beneath the East African Rift system : geochemical evidence from the Kivu volcanic province. Lithos 48, 237-262.

Furman, T., Kaleta, K.M., Bryce, J.G., Hanan, B.B., 2006. Tertiary mafic lavas of Turkana, Kenya: Constraints on East African plume structure and the occurrence of high- $\mu$ volcanism in Africa. J. Petrology 47, 1221-1244.

Gerlach, D.C., Cliff, R.A., Davies, G.R., Norry, M., Hodgson, N., 1988. Magmas sources of the Cape Verdes archipelago: Isotopic and trace element constraints. Geochim. Cosmochim. Acta 52, 2979-2992.

Geyer, A., Marti, J., 2008. The new worlwide collapse caldera database (CCDB): A tool for studying and understanding caldera processes. J. Volcanol. Geotherm. Res. 175, 334-354.

Gouhier, J., Nougier, J., Nougier, D., 1974. Contribution à l'étude volcanologique du Cameroun («Ligne du Cameroun »-Adamawa). Ann. Fac. Sci. Univ. Yaoundé Cameroun $17,3-48$.

Haggerty, S.E., 1976. Opaque mineral oxides in terrestrial igneous rocks. In: Rumble, D. III (Ed.) Reviews in mineralogy. Miner. Soc. Amer. Washington 3, pp. 101-300.

Halliday, A.N., Dickin, A.P., Fallick, A.E., Fitton, J.G., 1988. Mantle dynamics: a Nd, Sr, Pb and O isotopic study of the Cameroon Line Volcanic Chain. J. Petrology 29, 181-211. 
1046

1047

1048

1049

1050

1051

1052

1053

1054

1055

1056

1057

1058

1059

1060

1061

1062

1063

1064

1065

1066

1067

1068

1069

1070

1071

1072

1073

1074

1075

1076

Halliday, A.N., Davidson J.P., Holden, P., DeWolf, C., Lee, D.-C., Fitton, J.G., 1990. Traceelement fractionation in plumes and the origin of HIMU mantle beneath the Cameroon line. Nature 347, 523-528.

Halliday, A.N., Davies, G.R., Lee, D.-C., Tommasini, C.R., Paslick, J.G., Fitton, J.G., James, D.E., 1992. Lead isotope evidence for young trace element enrichment in the oceanic upper mantle. Nature 359, 623-627.

Hart, S.R., 1984. A large-scale isotope anomaly in the southern hemisphere mantle. Nature 309, 753-757.

Hoernle, K., Tilton, G., Schmincke, H.-U., 1991. Sr-Nd-Pb isotopic evolution of Gran Canaria: evidence for shallow enriched mantle beneath the Canary Islands. Earth Planet. Sci. Lett. 106, 44-63.

Itiga, Z., Chakam Tagheu, P.J., Wotchoko, P., Wandji, P., Bardintzeff, J.-M., Bellon, H., 2004. La ligne du Cameroun : Volcanologie et géochronologie de trois régions (mont Manengouba, plaine du Noun et Tchabal Gangdaba). Géochronique 91, 13-16.

Kagou Dongmo, A., 1998. Etude volcanologiquer, pétrographique et géochimique d'un volcan polygénique de la Ligne du Cameroun : le Mont Manengouba. Thèse $3^{\text {ème }}$ cycle, Univ. Yaoundé I, Cameroon, 197p.

Kagou Dongmo, A., 2006. Le mont Manengouba : évolution volcanologique, caractères magmatologiques et risques naturels; comparaison avec les monts Bambouto et Bamenda (Ligne du Cameroun). Thèse d'Etat, Univ. Yaoundé I, Cameroon, 239p.

Kagou Dongmo, A., Wandji, P., Pouclet, A., Vicat, J.-P., Cheilletz, A., Nkouathio, D.G., Alexandrov, P., Tchoua, F., 2001. Evolution volcanologique du mont Manengouba (Ligne du Cameroun), nouvelles données pétrographiques, géochimiques et géochronologiques. C. R. Acad. Sci. Paris, Sér IIa 333, 155-162.

Kagou Dongmo, A., Nkouathio, D., Pouclet, A., Bardintzeff, J.-M., Wandji, P., Nono, A., Guillou, H., 2010. The discovery of late Quaternary basalt on Mount Bambouto: Implications for recent widespread volcanic activity in the southern Cameroon Line. J. Afr. Earth Sci. 57, 96-108.

Kamgang, P., Chazot, G., Njonfang, E., Ngongang, N.B., Tchoua, F., 2013. Mantle sources and magma evolution beneath the Cameroon Volcanic Line: Geochemistry of mafic rocks from the Bamenda Mountains (NW Cameroon). Gondwana Res. 24, 727-741. 
1077 Kieffer, B., Arndt, N., Lapierre, H., Bastien, F., Bosch, D., Pecher, A., Yirgu, G., Ayalew, D.,

1078 Weis, D., Jerram, D.A., Keller, F., Meugniot, C., 2004. Flood and schield basalts from

1079

1080

1081

1082

1083

1084

1085

1086

1087

1088

1089

1090

1091

1092

1093

1094

1095

1096

1097

1098

1099

1100

1101

1102

1103

1104

1105

1106

1107

1108

1109

Ethiopia: Magmas from the African Superswell. J. Petrology 45, 793-834.

Kinzler, R.J., 1997. Melting of mantle peridotite at pressures approaching the spinel to garnet transition: application to mid-ocean ridge basalt petrogenesis. J. Geophys. Res. 102, 853874.

Lamilen, B.D., 1989.Contribution à l'étude du complexe anorogénique du mont Koupé : un exemple de série alcaline incomplète. Thèse $3^{\text {ème }}$ cycle, Univ. Yaoundé I, Cameroon, $169 \mathrm{p}$.

Le Bas, M.J., Le Maitre, R.W., Streckeisen, A., Zanettin, B., 1986. A chemical classification of volcanic rocks based on the Total Alkali-Silica diagram. J. Petrology 27, 745-750.

Lee, D.-C., Halliday, A.N., Fitton, J.G., Poli, G., 1994. Isotopic variations with distance and time in the volcanic islands of the Cameroon line: evidence for a mantle plume origin. Earth Planet. Sci. Lett. 123, 119-138.

Lee, D.-C., Halliday, A.N., Davies, G.R., Essene, E.J., Fitton, J.G., Temdjim, R., 1996. Melt enrichment of shallow depleted mantle: a detailed petrological, trace element and isotopic study of mantle-derived xenoliths and megacrysts from the Cameroon Line. J. Petrology 37, 415-441.

Marzoli, A., Piccirillo, E.M., Renne, P.R., Bellieni, G., Iacumin, M., Nyobe, J.B., Tongwa, A.T., 2000. The Cameroon volcanic line revisited: Petrogenesis of continental basaltic magmas from lithospheric and asthenospheric mantle source. J. Petrology 41, 87-109.

Matsukage, K.N., Oya, M., 2010. Petrological and chemical variability of peridotite xenoliths from the Cameroon volcanic line, West Africa: an evidence for plume emplacement. J. Miner. Petrol. Sci. 105, 57-69.

Mbassa, B.J., Njonfang, E., Benoit, M., Kamgang, P., Grégoire, M., Duchene, S., Brunet, P., Ateba, B, Tchoua, F., 2012. Mineralogy, geochemistry and petrogenesis of the recent magmatic formations from Mbengwi, a continental sector of the Cameroon Volcanic Line (CVL), Central Africa. Miner. Petrol. 106, 217-242.

McDonough, W.F., Sun, S.-s., 1995. The composition of the Earth. Chemical Geology 120, 223-253.

Meyers, J.B., Rosendahl, B.R., Harrison, C.G.A., Ding, Z.-D., 1998. Deep-imaging seismic and gravity results from the offshore Cameroon Volcanic Line, and speculation of African hotlines. Tectonophysics 284, 31-63. 
1110

1111

1112

1113

1114

1115

1116

1117

1118

1119

1120

1121

1122

1123

1124

1125

1126

1127

1128

1129

1130

1131

1132

1133

1134

1135

1136

1137

1138

1139

1140

1141

1142

Millet, M.-A., Doucelance, R., Schiano, P., David, K., Bosq, C., 2008. Mantle plume heterogeneity vs. shallow-level interactions: A case study, the São Nicolau Island, Cape Verde archipelago. J. Volcanol. Geotherm. Res. 176, 265-276.

Mitchell-Thomé, R.C., 1980. The calderas of Macaronesia. Boletim do Museu Municipal do Funchal 33 (141), 5-43.

Moreau, C., Regnoult, J.-M., Déruelle, B., Robineau, B., 1987. A new tectonic model for the Cameroon line, Central Africa. Tectonophysics 139, 317-334.

Münker, C., Pfänder, J.A., Weyer, S., Büchl, A., Kleine, T., Mezger, K., 2003. Evolution of planetary cores and the Earth-Moon system from $\mathrm{Nb}$ /Ta systematics. Science 301, 84-87.

Munro, D.C., Rowland, S.K., 1996. Caldera morphology in the western Galapagos and implications for volcano eruptive behaviour and mechanism of caldera formation. J. Volcanol. Geotherm. Res. 72, 85-100.

Nkouandou, O.F., Ngounouno, I., Déruelle, B., Ohnenstetter, D., Montigny, R., Demaiffe, D., 2008. Petrology of the Moi-Pliocene volcanism to the North and East of Ngaoundéré (Adamawa, Cameroon). C. R. Geoscience 340, 28-37.

Nkouathio, D.G., Ménard, J.-J., Wandji, P., Bardintzeff, J.-M., 2002. The Tombel graben (West Cameroon): a recent monogenetic volcanic field of the Cameroon Line. J. Afr. Earth Sci. 35, 285-300.

Nkouathio, D.G., Kagou Dongmo, A., Bardintzeff, J.-M., Wandji, P., Bellon, H., Pouclet, A., 2008. Evolution of volcanism in graben and horst structures along the Cenozoic Cameroon Line (Africa): implications for tectonic evolution and mantle source composition. Miner. Petrol. 94, 287-303.

Nsifa Nkonguin, E., Tchameni, R., Nédélec, A., Siqueira, R., Pouclet, A., Bascou, J., 2013. Structure and petrology of Pan-African nepheline syenites from the South West Cameroon; Implications for their emplacement mode, petrogenesis and geodynamic significance. J. Afr. Earth Sci. 87, 44-58.

O'Neill, H.St.C., 1981. The transition between spinel lherzolite and garnet lherzolite and its use as a geobarometer. Contrib. Mineral. Petrol. 77, 185-194.

O’Nions, R.K., Hamilton, P.J., Evensen, N.M., 1977. Variations in ${ }^{143} \mathrm{Nd} /{ }^{144} \mathrm{Nd}$ and ${ }^{87} \mathrm{Sr} /{ }^{86} \mathrm{Sr}$ in oceanic basalts. Earth Planet. Sci. Lett. 34, 13-22.

Paslick, C., Halliday, A., James, D., Dawson, J.B., 1995. Enrichment of the continental lithosphere by OIB melts: Isotopic evidence from the volcanic province of northern Tanzania. Earth Planet. Sci. Lett. 130, 109-126. 
1143 Pasyanos, M.E., Nyblade, A.A., 2007. A top to bottom lithospheric study of Africa and 1144 Arabia. Tectonophysics 444, 27-44.

1145 Pik, R. Marty, B., Hilton, D.R., 2006. How many plumes in Africa? The geochemical point of 1146 view. Chemical Geology 226, 100-114.

1147 Pfänder, J.A., Münker, C., Stracke, A., Mezger, K., 2007. Nb/Ta and Zr/Hf in ocean island 1148 basalts - Implications for crust-mantle differentiation and the fate of niobium. Earth 1149 Planet. Sci. Lett. 254, 158-172.

1150 Pfänder, J.A., Jung, S., Münker, C., Stracke, A., Mezger, K., 2012. A possible high Nb/Ta

1151 reservoir in the continental lithospheric mantle and consequences on the global $\mathrm{Nb}$ budget

$1152-$ Evidence from continental basalts from Central Germany. Geochim. Cosmochim. Acta $1153 \quad 77,232-251$.

1154 Platz, T., Foley, S.F., André, L., 2004. Low-pressure fractionation of the Nyiragongo volcanic 1155 rocks, Virunga Province, D.R. Congo. J. Volcanol. Geotherm. Res. 136, 269-295.

1156 Poudjom Djomani, Y.H., Nnange, J.M., Diament, M., Ebinger, C.J., Fairhead, J.D., 1995.

1157 Effective elastic thickness and crustal thickness variations in west-central Africa inferred

1158 from gravity data. J. Geophys. Res. 100, 22047-22070.

1159 Poudjom Djomani, Y.H., Diament, M., Wilson, M., 1997. Lithospheric structure across the

1160 Adamawa plateau (Cameroon) from gravity studies. Tectonophysics 273, 317-327.

1161 Putirka, K., 2008. Thermometers and barometers for volcanic systems. In: Putirka, K.,

1162 Tepley, F. (Eds.) Minerals, inclusions and volcanic processes. Review in mineralogy and

1163 geochemistry, Miner. Soc. Am. 69, pp. 61-120.

1164 Putirka, K.D., Mikaelian, H., Ryerson, F., Shaw, H., 2003. New clinopyroxene-liquid

1165 thermobarometers for mafic, evolved, and volatile-bearing lava compositions, with

1166 applications to lavas from Tibet and the Snake River Plain, Idaho. Am. Mineralogist 88,

1167 1542-1554.

1168 Putirka, K.D., Perfit, M., Ryerson F.J., Jackson, M. G., 2007. Ambient and excess mantle

1169 temperatures, olivine thermometry, and active vs.. passive upwelling. Chemical Geology

$1170>241,177-206$.

1171 Rankenburg, K., Lassiter, J.C., Brey, G., 2005. The role of continental crust and lithospheric

1172 mantle in the genesis of Cameroon Volcanic Line lavas: Constraints from isotopic

1173 variations in lavas and megacrysts from the Biu and Jos Plateaux. J. Petrology 46, 169-

1174190.

1175 Roeder, P.L., Emslie, R.F., 1970. Olivine-liquid equilibrium. Contrib. Mineral. Petrol. 29,

$1176 \quad 275-289$. 
1177 Rogers, N.W., De Mulder, M., Hawkesworth, C.J., 1992. An enriched mantle source for 1178 potassic basanites: evidence from Karisimbi volcano, Virunga volcanic province, Rwanda. Contrib. Mineral. Petrol. 111, 543-556.

1180

1181

1182

1183

1184

1185

1186

1187

1188

1189

1190

1191

1192

1193

1194

1195

1196

1197

1198

1199

1200

1201

1202

1203

1204

1205

1206

1207

1208

1209

1210

Rogers, N.W., James, D., Kelley, S.P., De Mulder, M., 1998. The generation of potassic lavas from the Eastern Virunga Province, Rwanda. J. Petrology 39, 1223-1247.

Rogers, N.W., Macdonald, R., Fitton, J.G., George R., Smith M., Barreiro, B., 2000. Two mantle plumes beneath the East African Rift system: $\mathrm{Sr}, \mathrm{Nd}$ and $\mathrm{Pb}$ isotope evidence from Kenya rift basalts. Earth Planet. Sci. Lett. 176, 387-400.

Rollinson, H., 1993. Using geochemical data: Evaluation, presentation, interpretation. Longman Group UK Limited, 352 pp.

Rudnick, R.L., McDonough, W.F., Chappell, B.W., 1993. Carbonatite metasomatism in the northern Tanzanian mantle: petrographic and geochemical characteristics. Earth Planet. Sci. Lett. 114, 463-475.

Rudnick, R.L., Gao, S., 2003. Composition of the continental crust. In: Holland, H.D., Turekian, K.K. (Eds.) Treatise on geochemistry, Vol. 3 The crust, pp 1-64, ElsevierPergamon, Oxford, 683p.

Salters, V.J.M., Longhi, J., 1999. Trace element partitioning during the initial stages of melting beneath mid-ocean ridges. Earth Planet. Sci. Lett. 166, 15-30.

Salters, V.J.M., Longhi, J.E., Bizimis, M., 2002. Near mantle solidus trace element partitioning at pressure up to $3.4 \mathrm{GPa}$. Geochem. Geophys. Geosyst. 3. doi:10.1029/2001GC000148.

Salters, V.J.M., Stracke, A., 2004. Composition of the depleted mantle. Geochem. Geophys. Geosyst. 5, 27. doi:10.1029/2003GC000597, Q05004.

Schilling, M., Conceição, R.V., Mallmann, G., Koester, E., Kawashita, K., Hervé, F., Morata, D., Motoki, A., 2005. Spinel-facies mantle xenoliths from Cerro Redondo, Argentine Patagonia: Petrographic, geochemical, and isotopic evidence of interaction between xenoliths and host basalt. Lithos 82, 485-502.

Steiger, R.H., Jäger, E., 1977. Subcommission on geochronology: convention on the use of decay constants in geo- and cosmochronology. Earth Planet. Sci. Lett. 36, 359-362.

Stracke, A., Hofmann, W., Hart, S.R., 2005. FOZO, HIMU, and the rest of the mantle zoo. Geochem. Geophys. Geosyst. 6, Q05007, doi:10.1029/2004GC000824.

Stormer, J.C., 1983. The effects of recalculation on estimates of temperature and oxygen fugacity from analyses of multicomponent iron-titanium oxides. Am. Mineralogist 68, 586-594. 
1211 Suh, C.E., Sparks, R.S.J., Fitton, J.G., Ayonghe, S.N., Annen, C., Nana, R., Luckman, A.,

1212 2003. The 1999 and 2000 eruptions of Mount Cameroon: eruption behaviour and

1213 petrochemistry of lava. Bull. Volcanol. 65, 267-281.

1214 Sun, S.S., McDonough, W.F., 1989. Chemical and isotopic systematics of oceanic basalts:

1215 implications for mantle composition and processes. In: Saunders, A.D., Norry, M.J. (Eds.)

1216 Magmatism in ocean basins. Geol. Soc. London, Special Publication 42, pp 313-345.

1217 Tchoua, F., 1974. Contribution à l'étude géologique et pétrologique de quelques volcans de la

1218 «igne du Cameroun» (Monts Manengouba et Bambouto). Thèse $3^{\text {ème }}$ cycle, Univ.

$1219 \quad$ Clermont-Ferrand, France.

1220 Temdjim, R., 2012. Ultramafic xenoliths from Lake Nyos area, Cameroon volcanic line,

1221 West-central Africa: Petrography, mineral chemistry, equilibration conditions and

1222 metasomatic features. Chemie der Erdre 72, 39-60.

1223 Temdjim, R., Boivin, P., Chazot, G., Robin, C., Rouleau, E., 2004. L’hétérogénéité du

1224 manteau supérieur à l'aplomb du volcan de Nyos (Cameroun) révélée par les enclaves

1225 ultrabasiques. C. R. Geoscience 336, 1239-1244.

1226 Thornton, C.P., Tuttle, O.F., 1960. Chemistry of igneous rocks. I, differentiation index. Am.

1227 J. Sci. $258,664-684$.

1228 Tokam, A.P.K., Tabod, C.T., Nyblade, A.A., Julia, J., Wiens, D.A., Pasyanos, M.E., 2010.

1229 Structure of the crust beneath Cameroon, West Africa, from the joint inversion of

1230 Rayleigh wave group velocities and receiver functions. Geophysical Journal International

$1231 \quad 183,1061-1076$.

1232 Vicat, J.-P., Pouclet, A., Bellion, Y., Doumnang, J.-C., 2002. Les rhyolites hyperalcalines

1233 (pantellérites) du lac Tchad. Composition et signification tectonomagmatique. C. R.

1234 Géoscience 224, 885-891.

1235 Wandji. P., Tsafack, J.P.F., Bardintzeff, J.M., Nkouathio, D.G., Kagou Dongmo, A., Bellon,

1236 H., Guillou, H., 2009. Xenoliths of dunites, wehrlites and clinopyroxenites in the basanites from Batoke volcanic cone (Mount Cameroon, Central Africa): petrogenetic

1239 Walter, M.J., 1998. Melting of garnet peridotite and the origin of komatiite and depleted

1240 lithosphere. J. Petrology 39, 29-60.

1241 Workman, R.K., Hart, S.R., 2005. Major and trace element composition of the depleted

1242 MORB mantle (DMM). Earth Planet. Sci. Lett. 231, 53-72. 
1243 Wotchoko, P., Wandji, P., Bardintzeff, J.-M., Bellon, H., 2005. Données pétrologiques et 1244 géochronologiques nouvelles sur le volcanisme alcalin néogène à récent de la rive ouest du Noun (plaine du Noun, Ligne du Cameroun). Review Bulgarian Geol. Soc. 66, 97-105.

Yokoyama, T., Aka, F.T., Kusakabe, M., Nakamura, E., 2007. Plume-lithosphere interaction beneath Mt. Cameroon volcano, West Africa: Constraints from ${ }^{238} \mathrm{U}_{-}{ }^{230} \mathrm{Th}_{-}{ }^{226} \mathrm{Ra}$ and $\mathrm{Sr}-$ $\mathrm{Nd}-\mathrm{Pb}$ isotope systematics. Geochim. Cosmochim. Acta 71, 1835-1854.

Youmen, D., Schmincke, H.-U., Lissom, J., Etame, J., 2005. Données géochronologiques : mise en évidence des différentes phases volcaniques au Miocène dans les monts Bambouto (Ligne du Cameroun). Sci. Technol. Dev. 11, 49-57.

Zack, T., Foley, S.F., Jenner, G.A., 1997. A consistent partition coefficient set for clinopyroxene, amphibole and garnet from laser ablation microprobe analysis of garnet pyroxenites from Kakanui, New Zealand. Neues Jahrbuch für Mineralogie, Abh. 172, 23 41.

Zindler, A., Hart, S.R., 1986. Chemical geodynamics. Ann. Rev. Earth Planet. Sci. 14, 493571.

1258

1259

1260

1261

1262

1263

1264

1265

1266

1267

1268

1269 1270

1271

1272

1273

1274

1275

\section{Caption}

Fig. 1. A) The Mount Manengouba and the great volcanoes in the Cameroon Line. B) Main structural features of the Mt Manengouba are on a Digital Elevation Model (Image Landsat 7 ETM Satellite Imagery, data set: SRTM, Producer: USGS/GLCF, Date 2000, ID 045-76 Cameroon). Nk, Nkongsamba town. N, Nlonako, and K, Koupé, Eocene syenitic alkaline intrusions.

Fig. 2. Geological map of the Manengouba. Main units of the volcano: 1) stacked lavas of the middle and low slopes of the shield, 2) the Eboga stratovolcano, 3) the Elengoum Extrusive Complex, and 4) the flank cones and flows of the late parasitic activity.

Fig. 3. Detailed map of the Eboga caldera, Elengoum complex and south-eastern low flank showing the pre-Manengouba flows preserved along the Nlonako syenite massif. Most of the age data locate in this area. DS, phreatomagmatic crater of Djeu Sey; LF, maar of the "Lac de la femme"; LH, maar of the "Lac de l'homme"; MB, plug-dome of Mbouroukou; SCSV, supra-caldera strombolian volcanic complex. 
1277 Fig. 4. Detailed map of the north-western low slope showing the age data of flank activity and of the pre-Manengouba trachy-phonolite extrusions of Ekomane and Bakossi.

Fig. 5. Ar/Ar plateau ages.

1282 Fig. 6. Sketch of the four stages of the volcanic activities.

Fig. 7. Nomenclature of the Manengouba lavas. $\mathrm{A}, \mathrm{SiO}_{2}$ vs. $\mathrm{Na}_{2} \mathrm{O}+\mathrm{K}_{2} \mathrm{O}$ diagram after Le Bas et al. (1986). B, DI vs. normative quartz or nepheline diagram displaying the undersaturation of the series. DI, Differentiation Index of Thornton and Tuttle (1960).

Fig. 8. Fo\% vs. $\mathrm{CaO}$ (wt.\%) diagram of olivines: A) Group 1; B) Group 2. In both groups, phenocrysts, microcrysts, as well as xenocrysts crystallized from a related suite of magmas.

Fig. 9. Mg\# vs. Fo diagram of whole rock and olivine compositions. The Mg number is calculated assuming a wt. $\% \mathrm{Fe}_{2} \mathrm{O}_{3} / \mathrm{FeO}$ ratio of 0.15 . The olivine-liquid equilibrium temperature is calculated after the equation (4) of Putirka et al. (2007). The liquid temperature is calculated after the equation (15) of Putirka (2008). The pressure of the main magma chamber is estimated at $1 \mathrm{GPa}$ according to the clinopyroxene-liquid thermobarometer of Putirka et al. (2003) and Putirka (2008). Distribution coefficient $K_{D}=(X O 1 / F e O) /(X L i q / F e O)$ $\mathrm{x}(\mathrm{XLiq} / \mathrm{MgO}) /(\mathrm{XOl} / \mathrm{MgO})$ of Roeder and Emslie (1970). Same symbols as for Figure 8.

Fig. 10. $\mathrm{Fe}^{2+} /\left(\mathrm{Fe}^{2+}+\mathrm{Mg}\right)$ vs. $\mathrm{Ti} /(\mathrm{Ti}+\mathrm{Al}+\mathrm{Cr})$ diagram of Ti-magnetites of Groups 1 and 2.

1300 Projections from the multicomponent spinel prism (Haggerty, 1976). From basanite to hawaiite, magnetites display decreasing $\mathrm{Ti}$ and $\mathrm{Fe}^{2+}$ ratios due to decreasing $\mathrm{Al}$ and $\mathrm{Mg}$ contents in Group 1, and decreasing $\mathrm{Cr}, \mathrm{Al}$ and $\mathrm{Mg}$ contents in Group 2. Mugearite and benmoreite phenocrysts are similar to those of hawaiite, while microcrysts are depleted in $\mathrm{Al}$ and Mg. Trachyte microcrysts only contain Fe and Ti.

Fig. 11. $10^{4} / \mathrm{T}(\mathrm{K})$ vs. $\ln \left(\mathrm{K}_{\mathrm{D}}{ }^{\mathrm{Fe}-\mathrm{Mg}}\right)$ of pyroxenes, according to Putirka et al. (2003), for

1307 illustrating the distribution of phenocrysts in equilibrium with liquids, microcrysts of the

1308 evolved groundmasses, and xenocrysts inherited from more mafic magmas crystallized in the 1309 magma chamber. Pyroxenes of the more differentiated benmoreites and trachytes could be 
1310 either xenocrysts or phenocrysts of a liquid that was disturbed by post-pyroxene

1311 crystallization processes. $\mathrm{K}_{\mathrm{D}}$ is calculated assuming a wt. $\% \mathrm{Fe}_{2} \mathrm{O}_{3} / \mathrm{FeO}$ ratio of 0.15 for

1312 liquids and using the pyroxene calculated $\mathrm{FeO}$ contents.

1313

1314 Fig. 12. Mg-Ca-Fet+Mn diagram of Group 1 pyroxenes.

1315

1316 Fig. 13. $\mathrm{Al}^{\mathrm{IV}}$ vs. $\mathrm{Al}^{\mathrm{VI}}$, Ti vs. $\mathrm{Al}^{\mathrm{VI}}$, and $\mathrm{Ti}$ vs. Na diagrams. Symbols as for Figure 12.

1318 Fig. 14. Mg-Ca-Fet+Mn diagram of Group 2 pyroxenes.

1319

Fig. 15. $\mathrm{Al}^{\mathrm{IV}}$ vs. $\mathrm{Al}^{\mathrm{VI}}, \mathrm{Fe}^{2+}$ vs. Ti, and $\mathrm{Al}$ vs. Ti diagrams. Symbols as for Figure 14.

Fig. $16 \mathrm{~A}$ and B. $\mathrm{MgO}$ wt.\% vs. major and minor elements covariation diagrams. Symbols as 1323 for Figure 7.

1324

1325 Fig. 17. Chondrite normalized rare earth element patterns for A) stages 1 and 2 lavas, B) stage

13263 lavas, C) stage 4 lavas, and D) pre-Manengouba lavas. Normalizing values after

1327 McDonough and Sun (1995).

1328

Fig. 18. N-MORB normalized incompatible trace element patterns for A) stages 1 and 2 lavas, B) stage 3 lavas, C) stage 4 lavas, and D) pre-Manengouba lavas. Normalizing values after Sun and McDonough (1989).

1333 Fig. 19. $\mathrm{Th} / \mathrm{Pb}$ vs. $\mathrm{Ce} / \mathrm{Pb}$ diagram showing the crustal assimilation in the Manengouba 1334 trachytes and in the Bakossi phonolites. Bulk continental crust after Rudnick and Gao (2003).

Fig. 20. Covariation of $\mathrm{MgO}$ and vs. Ni for Group 1 (Stages 1 and 2) and Group 2 (Stage 4) mafic lavas. Partial melting area of primitive mantle drawn after Class et al. (1994). CT46 and EB20 are close to the primitive mantle melts with, respectively Mg\# of 60 and 63 and $\mathrm{Ni}$ (ppm) of 222 and 238. Parental magmas may average 9 to $10 \mathrm{wt} . \%$ of $\mathrm{MgO}$ and 250 to 290 ppm of $\mathrm{Ni}$ in resulting from about $5 \%$ of partial melting. The two almost similar fractional trends of the two magmatic groups extend until 15 to $20 \%$ of olivine fractionation. 
1343 Fig. 21. N-MORB normalized incompatible trace element patterns restricted to mafic lavas of 1344 the Manengouba main building (Group 1, stages 1 and 2) and of the late parasitic activity

1345 (Group 2, stage 4). OIB pattern after Sun and McDonough (1989).

1347 Fig. 22. A) $\mathrm{Ta} / \mathrm{Yb}$ vs. $\mathrm{Th} / \mathrm{Yb}$ diagram. B) $\mathrm{Zr} / \mathrm{Hf}$ vs. Nb/Ta diagram.

1348 PM, N-MORB, E-MORB, and OIB from Sun and McDonough (1989); DMM from Salters 1349 and Stracke (2004); chondritic values from Münker et al. (2003); MORB, OIB, and 1350 continental basalts fields after Pfänder et al. (2007); Kenya rift and Virunga fields drawn with 1351 the data of Rogers et al. (1992, 1998, 2006), Platz et al. (2004), and Chakrabarti et al. (2009).

1353 Fig. 23. A) La vs. La/Sm and B) La/Sm vs. Sm/Yb diagrams for determining the enrichment 1354 of the source and the partial melting degrees of the mantle source. The La vs. La/Sm diagram 1355 suggests a source enrichment similar to that of the E-MORB and a degree of partial melting 1356 between $2 \%$ and $5 \%$ on the lherzolite melt curves. Once this source is admitted, the La/Sm vs. $1357 \mathrm{Sm} / \mathrm{Yb}$ diagram suggests a spinel-garnet lherzolite source composition with a 50:50 mixture 1358 of spinel and garnet. Modal compositions of spinel-lherzolite (olivine 53\%, OPX 27\%, CPX $135917 \%$, spinel 3\%) and garnet-lherzolite (olivine 60\%, OPX 20\%, CPX 10\%, garnet 10\%) are 1360 after Kinzler (1997) and Walter (1998). Mineral/melt partition coefficients for basaltic liquids 1361 are after the compilation of Rollinson (1993). Primitive Mantle (PM), N-MORB, and E-

1362 MORB compositions are from Sun and McDonough (1989). Depleted MORB mantle (DMM) 1363 from Salters and Stracke (2004).

1364

1365 Fig. 24. A, B, and C, ${ }^{86} \mathrm{Sr} /{ }^{87} \mathrm{Sr}$ vs. ${ }^{143} \mathrm{Nd} /{ }^{144} \mathrm{Nd},{ }^{206} \mathrm{~Pb} /{ }^{204} \mathrm{~Pb}$ vs. ${ }^{207} \mathrm{~Pb} /{ }^{204} \mathrm{~Pb}$, and ${ }^{206} \mathrm{~Pb} /{ }^{204} \mathrm{~Pb}$ vs. $1366{ }^{208} \mathrm{~Pb} /{ }^{204} \mathrm{~Pb}$ diagrams (time corrected values) for the Manengouba and pre-Manengouba lava 1367 analyses of this study completed by the Manengouba mafic lava analyses of Halliday et al. 1368 (1988 and 1990). These data are compared with the whole data for mafic lavas of the 1369 Cameroon Volcanic Line plotted in six fields from north to south: Biu-Mandara, Ngaoundéré, 1370 middle continental shields (Oku, Bamenda, Bambouto, Manengouba, and Tombel), continent1371 ocean boundary (Mt Cameroon, Etinde, Bioko), Principe-São Tomé, and Pagalu. See text for 1372 the references. DMM, HIMU, PREMA, BSE, EM1, and EM2 after O'Nions et al. (1977), 1373 Zindler and Hart (1986), Rollinson (1993); FOZO after Stracke et al. (2005); EDMM after 1374 Workman and Hart (2005). 
1375

1376

1377

1378

1379

1380

1381

1382

1383

1384

1385

1386

1387

1388

1389

1390

1391

1392

1393

1394

1395

1396

1397

1398

1399

1400

1401

1402

1403

1404

1405

1406

1407

1408

D, ${ }^{86} \mathrm{Sr} /{ }^{87} \mathrm{Sr}$ vs. ${ }^{206} \mathrm{~Pb} /{ }^{204} \mathrm{~Pb}$ diagram for showing the three theoretical components of magmatic sources of the Cameroon Volcanic Line. DC, depleted component; RC, radiogenic component; EC, enriched component. Explanation of the trends, see text.

Table 1. New radiochronological data. K/Ar analyses were done by $\mathrm{H}$. Bellon at the Laboratory of Geochronology of the "Université de Bretagne Occidentale", Brest, France. Ar/Ar analyses were done by G. Ruffet at the Laboratory of Geochronology of the “Université de Rennes 1", Rennes, France. CNRS (CNRS/INSU) UMR 6118, Géosciences Rennes, 35042 Rennes Cedex, and Université de Rennes I, Géosciences Rennes, 35042 Rennes Cedex, France. Age calculation was carried on using the constants of Steiger and Jäger (1977). Data, parameters used for Ar/Ar calculations (isotopic ratios measured on K, Ca and $\mathrm{Cl}$ pure salts; mass discrimination; atmospheric argon ratios; $\mathrm{J}$ parameter; decay constants) and reference sources are available in the supplementary data repository.

Table 2. Report of the available chronological data for the Manengouba area distributed in age groups.

Table 3. Petrographical composition of Group 1 (A) and Group 2 (B) lavas. X'USP, apparent mole fraction of ulvöspinel according to Stormer (1983).

Table 4. Representative chemical analyses of minerals: A, Olivine; B, Magnetite; C, Ilmenite. D, Clinopyroxene; E, Amphibole; F, Mica; G, Feldspar.

Alk-B, alkaline basalt; Ank, ankaratrite; Bn, benmoreite; Bs, basanite; Na-Bs, sodic basanite; $\mathrm{H}$, hawaiite; $\mathrm{M}$, mugearite; $\mathrm{Tr}$, trachyte.

Table 5. Chemical analyses of the rocks. Petrographical facies as for Table 4 plus Na-H, sodic hawaiite; $\mathrm{Ph}$, phonolite; $\mathrm{Rh}$, rhyolite; $\mathrm{Tr}-\mathrm{Ph}$, trachy-phonolite. DI (Differentiation Index) after Thornton and Tuttle (1960). Analyses by ICP-AES (major elements) and ICP-MS (minor and trace elements) at the Centre de Recherches Pétrographiques et Géochimiques (CRPG, CNRS) of Nancy, France.

Table 6. $\mathrm{Sr}, \mathrm{Nb}$, and $\mathrm{Pb}$ isotope data. MS measurements (VG Sector 54 TIMS) at the Université libre of Bruxelles (Belgium). Analyst: Daniel Demaiffe. 
KPB-Table 1

$\mathrm{K} / \mathrm{Ar}$ analyses

\begin{tabular}{|c|c|c|c|c|c|c|}
\hline CT107 Tr & Essom peak & 5.31 & 86.5 & 23.29 & 1.24 & $13.56 \pm 0.39$ \\
\hline CT103 Ph & W-Bangem & 5.26 & 82.5 & 12.82 & 0.93 & $7.55 \pm 0.18$ \\
\hline CT155 Rh & Ekom & 4.46 & 41.6 & 1.46 & 0.7 & $1.02 \pm 0.03$ \\
\hline CT108 H & Mboassoum (flank activity) & 1.25 & 6.1 & 0.18 & 0.94 & $0.45 \pm 0.07$ \\
\hline CT47 H & Melong (flank activity) & 1.38 & 9.55 & 0.2 & 0.51 & $0.45 \pm 0.04$ \\
\hline CT52 M & Nyam-Enyandong (flank activity) & 2.19 & 1.6 & 0.28 & 6.27 & $0.40 \pm 0.23$ \\
\hline CT105 T-P & W-Bangem (flank activity) & 4.12 & 11.9 & 0.28 & 0.71 & $0.21 \pm 0.02$ \\
\hline CT55 Bs & Ekoh (flank activity) & 1.7 & 3.5 & 0.059 & 1.662 & $0.11 \pm 0.03$ \\
\hline
\end{tabular}

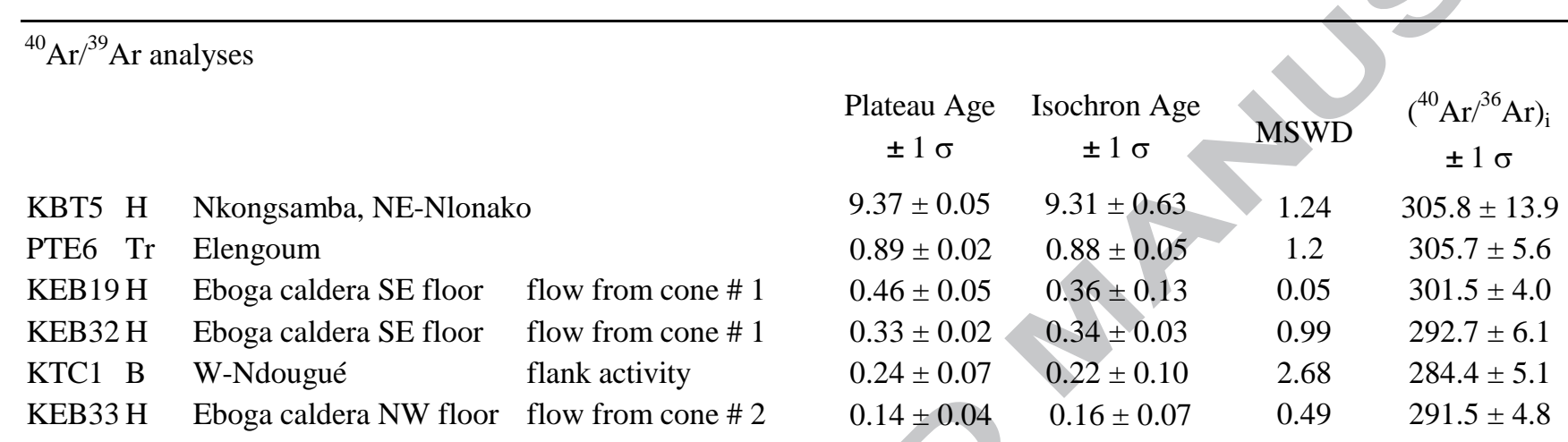


KPB-Table 2

Pre-Manengouba volcanic rocks

Northwestern and eastern borders

Extrusions of trachyte and phonolite and mafic lava flows

CT107 Tr 13.56 \pm 0.39 Essom peak K4

C54 Tr 11.82 \pm 0.47 Ekomane K2

KBT5 H $9.37 \pm 0.05$ Nkongsamba A1

CT103 Ph $7.55 \pm 0.18$ W-Bangem

(K1) Gouhier et al. (1974)

(K2) Dunlop (1983)

(K3) Kagou et al. (2001)

(K4) new K/Ar data

(A1) new ${ }^{40} \mathrm{Ar} /{ }^{39} \mathrm{Ar}$ data

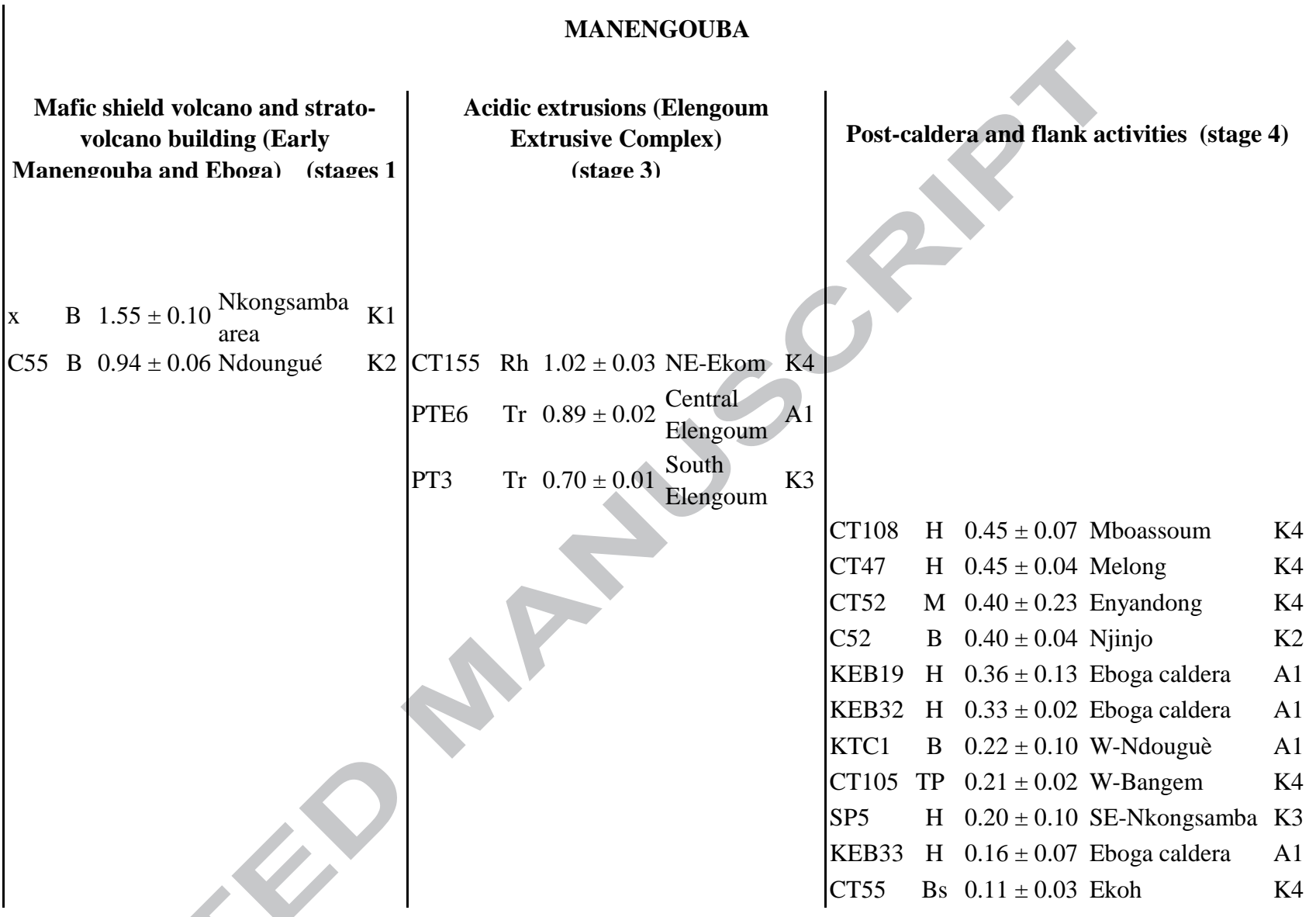


Magmatic Group \# 1

\begin{tabular}{|c|c|c|}
\hline Group 1 & Basanite - Alkali Basalt & Hawaiite \\
\hline Xenocrysts & $0.50 \%$ & $1 \%$ \\
\hline Olivine & $\begin{array}{c}84.5<\mathrm{Fo}<85.2 \\
0.25<\mathrm{CaO} \text { wt } \%<0.30\end{array}$ & $\begin{array}{c}83.2<\mathrm{Fo}<84.5 \\
0.23<\mathrm{CaO} w \mathrm{wt}<0.28\end{array}$ \\
\hline Clinopyroxene & $\begin{array}{c}40.5<\mathrm{XMg} \%<40.8 \\
13.6<\mathrm{XFet}+\mathrm{Mn} \%<13.8 \\
45.4<\mathrm{XCa} \%<45.9\end{array}$ & $\begin{array}{c}40.5<\mathrm{XMg} \%<43.4 \\
12.4<\mathrm{XFet}+\mathrm{Mn} \%<14.1 \\
42.4<\mathrm{XCa} \%<46.7\end{array}$ \\
\hline Feldspar & An 51-40 & An $62-59$ \\
\hline $\begin{array}{l}\text { Phenocrysts and } \\
\text { Microphenocrysts }\end{array}$ & $10-15 \%$ & $10-15 \%$ \\
\hline Olivine & $\begin{array}{c}77.1<\mathrm{Fo}<81.7 \\
0.19<\mathrm{CaO} \text { wt } \%<0.25\end{array}$ & $\begin{array}{c}69.0<\mathrm{Fo}<79.0 \\
0.22<\mathrm{CaO} \text { wt } \% 0.29\end{array}$ \\
\hline Magnetite & $\begin{array}{c}17.1<\mathrm{TiO}_{2} \mathrm{wt} \%<18.6 \\
4.2<\mathrm{Al}_{2} \mathrm{O}_{3} \mathrm{wt} \%<4.8 \\
4.9<\mathrm{MgO} \mathrm{Mt}^{2}<6.6 \\
0.48<\mathrm{X}^{\prime} \mathrm{Usp}<0.51\end{array}$ & $\begin{array}{c}17.2<\mathrm{TiO}_{2} \mathrm{wt}^{2}<20.9 \\
1.8<\mathrm{Al}_{2} \mathrm{O}_{3} \mathrm{wt} \%<5.2 \\
2.2<\mathrm{MgO} \text { wt } \%<4.6 \\
0.50<\mathrm{X}^{\prime} \mathrm{Usp}<0.64\end{array}$ \\
\hline Ilmenite & no accurate analyses & $\begin{array}{c}\mathrm{X}^{\prime} \mathrm{Ilm}=0.95 \\
\mathrm{Fe}^{3+} / \mathrm{Fe}^{2+}=0.12\end{array}$ \\
\hline Clinopyroxene & $\begin{array}{c}39.9<\mathrm{XMg} \%<44.0 \\
13.5<\mathrm{XFet}+\mathrm{Mn} \%<14.8 \\
41.8<\mathrm{XCa} \%<46.5\end{array}$ & $\begin{array}{c}39.4<\mathrm{XMg} \%<46.0 \\
11.7<\mathrm{XFet}+\mathrm{Mn} \%<16.6 \\
41.6<\mathrm{XCa} \%<47.5\end{array}$ \\
\hline \multicolumn{3}{|l|}{ Amphibole } \\
\hline \multicolumn{3}{|l|}{ Biotite } \\
\hline Feldspar & An 66-60 & An 60-51 \\
\hline \multicolumn{3}{|l|}{ Microcrysts } \\
\hline Olivine & $\begin{array}{c}74.1<\mathrm{Fo}<78.4 \\
0.16<\mathrm{CaO} \text { wt } \%<0.28\end{array}$ & $\begin{array}{c}57.9<\mathrm{Fo}<70.5 \\
0.19<\mathrm{CaO} \mathrm{wt} \%<0.44\end{array}$ \\
\hline Magnetite & $\begin{array}{c}18.3<\mathrm{TiO}_{2} \mathrm{wt} \%<20.7 \\
1.9<\mathrm{Al}_{2} \mathrm{O}_{3} \mathrm{wt} \%<2.4 \\
4.0<\mathrm{MgO} \mathrm{wt} \%<4.9 \\
0.50<\mathrm{X}^{\prime} \mathrm{usp}<0.61\end{array}$ & $\begin{array}{c}18.3<\mathrm{TiO}_{2} \mathrm{wt}^{2}<21.1 \\
2.3<\mathrm{Al}_{2} \mathrm{O}_{3} \mathrm{wt} \%<3.0 \\
1.8<\mathrm{MgO} \text { wt } \%<2.0 \\
0.57<\mathrm{X}^{\prime} \mathrm{usp}<0.64\end{array}$ \\
\hline Ilmenite & & $\begin{array}{c}\text { X'ilm }=0.93 \\
\mathrm{Fe}^{3+} / \mathrm{Fe}^{2+}=0.18\end{array}$ \\
\hline Clinopyroxene & $\begin{array}{c}38.9<\mathrm{XMg} \%<45.4 \\
14.5<\mathrm{XFet}+\mathrm{Mn} \%<17.8 \\
40.2<\mathrm{XCa} \%<45.8\end{array}$ & $\begin{array}{c}39.6<\mathrm{XMg} \%<42.8 \\
14.7<\mathrm{XFet}+\mathrm{Mn} \%<15.8 \\
41.7<\mathrm{XCa} \%<44.6\end{array}$ \\
\hline Feldspar & An $60-51$ & An 53-46 \\
\hline
\end{tabular}


Table 3B

Magmatic Group \# 2

\begin{tabular}{|c|c|c|c|}
\hline Group 2 & Basanite - Alkali Basalt & Hawaiite & Mugearite \\
\hline Xenocrysts & $0.50 \%$ & $1 \%$ & $2 \%$ \\
\hline Olivine & $\begin{array}{c}87.0<\mathrm{Fo}<86.5 \\
0.25<\mathrm{CaO} \text { wt } \%<0.20\end{array}$ & $\begin{array}{c}85.0<\mathrm{Fo}<82.5 \\
0.21<\mathrm{CaO} \text { wt } \%<0.19\end{array}$ & $\begin{array}{c}77.9<\mathrm{Fo}<77.3 \\
0.20<\mathrm{CaO} \text { wt } \%<0.18\end{array}$ \\
\hline Pyroxene & $\begin{array}{c}41.1<\mathrm{XMg} \%<47.9 \\
10.5<\mathrm{XFet}+\mathrm{Mn} \%<13.6 \\
41.6<\mathrm{XCa} \%<46.0\end{array}$ & $\begin{array}{c}41.1<\mathrm{XMg} \%<45.2 \\
9.2<\mathrm{XFet}+\mathrm{Mn} \%<15.0 \\
43.0<\mathrm{XCa} \%<46.3\end{array}$ & $\begin{array}{c}38.1<\mathrm{XMg} \%<42.8 \\
12.0<\mathrm{XFet}+\mathrm{Mn} \%<15.3 \\
41.7<\mathrm{XCa} \%<48.6\end{array}$ \\
\hline Feldspar & An 43-39 & & An $28-22$ \\
\hline $\begin{array}{l}\text { Phenocrysts and } \\
\text { Microphenocrysts }\end{array}$ & $10-15 \%$ & $5-10 \%$ & \\
\hline Olivine & $\begin{array}{c}83.0<\mathrm{Fo}<78.1 \\
0.30<\mathrm{CaO} \text { wt } \%<0.20\end{array}$ & $\begin{array}{c}78.7<\mathrm{Fo}<70.5 \\
0.37<\mathrm{CaO} \text { wt } \%<0.21 \\
\end{array}$ & $\begin{array}{c}77.1<\mathrm{Fo}<64.4 \\
0.32<\mathrm{CaO} \text { wt } \%<0.16\end{array}$ \\
\hline Magnetite & $\begin{array}{c}13.3<\mathrm{TiO}_{2} \mathrm{wt} \%<17.9 \\
4.8<\mathrm{Al}_{2} \mathrm{O}_{3} \mathrm{wt} \%<8.0 \\
5.0<\mathrm{MgO}^{\mathrm{wt}} \%<5.5 \\
3.5<\mathrm{Cr}_{2} \mathrm{O}_{3}<12.3 \\
0.60<\mathrm{X}^{\prime} \text { usp }<0.65\end{array}$ & $\begin{array}{c}16.8<\mathrm{TiO}_{2} \mathrm{wt} \%<22.1 \\
2.7<\mathrm{Al}_{2} \mathrm{O}_{3} \text { wt } \%<5.1 \\
3.5<\mathrm{MgO}^{\mathrm{wt}} \%<5.5 \\
0.1<\mathrm{Cr}_{2} \mathrm{O}_{3}<2.7 \\
0.53<\mathrm{X}^{\prime} \text { usp }<0.69\end{array}$ & $\begin{array}{c}17.2<\mathrm{TiO}_{2} \mathrm{wt} \%<21.8 \\
2.7<\mathrm{Al}_{2} \mathrm{O}_{3} \mathrm{wt} \%<5.7 \\
2.7<\mathrm{MgO} \text { wt } \%<4.6 \\
0.54<\mathrm{X}^{\prime} \text { usp }<0.67\end{array}$ \\
\hline Ilmenite & $\begin{array}{c}\text { X'ilm }=0.96 \\
\mathrm{Fe}^{3+} / \mathrm{Fe}^{2+}=0.09\end{array}$ & $\begin{array}{c}\text { X'ilm }=0.96 \\
\mathrm{Fe}^{3+} / \mathrm{Fe}^{2+}=0.10\end{array}$ & $\begin{array}{c}\text { X'ilm }=0.94 \\
\mathrm{Fe}^{3+} / \mathrm{Fe}^{2+}=0.13\end{array}$ \\
\hline Pyroxene & $\begin{array}{c}33.8<\mathrm{XMg} \%<48.5 \\
11.2<\mathrm{XFet}+\mathrm{Mn} \%<17.6 \\
38.6<\mathrm{XCa} \%<50.2\end{array}$ & $\begin{array}{c}40.0<\mathrm{XMg} \%<44.9 \\
11.9<\mathrm{XFet}+\mathrm{Mn} \%<17.1 \\
41.1<\mathrm{XCa} \%<45.1\end{array}$ & $\begin{array}{c}37.2<\mathrm{XMg} \%<43.6 \\
11.9<\mathrm{XFet}+\mathrm{Mn} \%<16.9 \\
42.1<\mathrm{XCa} \%<48.1\end{array}$ \\
\hline Amphibole & $\begin{array}{c}0.74<\mathrm{Mg} / \mathrm{Mg}+\mathrm{Fe}^{2+}<0.79 \\
3.7<\mathrm{TiO}_{2} \mathrm{wt} \%<4.7\end{array}$ & $\begin{array}{c}0.67<\mathrm{Mg} / \mathrm{Mg}+\mathrm{Fe}^{2+}<0.72 \\
5.2<\mathrm{TiO}_{2} \text { wt } \%<5.8\end{array}$ & $\begin{array}{c}0.67<\mathrm{Mg} / \mathrm{Mg}+\mathrm{Fe}^{2+}<0.79 \\
2.6<\mathrm{TiO}_{2} \mathrm{wt} \%<5.8\end{array}$ \\
\hline Biotite & & & $\begin{array}{c}0.76<\mathrm{Mg} / \mathrm{Mg}+\mathrm{Fe}^{2+}<0.80 \\
4.4<\mathrm{TiO}_{2} \mathrm{wt} \%<5.9\end{array}$ \\
\hline Feldspar & An 66-60 & An $60-50$ & An 55-43 \\
\hline \multicolumn{4}{|l|}{ Microcrysts } \\
\hline Olivine & $\begin{array}{c}78.7<\mathrm{Fo}<72.2 \\
0.40<\mathrm{CaO} \text { wt } \%<0.16\end{array}$ & $\begin{array}{c}71.2<\mathrm{Fo}<65.8 \\
0.35<\mathrm{CaO} \text { wt } \%<0.27\end{array}$ & $\begin{array}{c}62.9<\mathrm{Fo}<54.0 \\
0.42<\mathrm{CaO} \text { wt } \%<0.26 \\
\end{array}$ \\
\hline Magnetite & $\begin{array}{c}16.7<\mathrm{TiO}_{2} \mathrm{wt} \%<20.1 \\
3.3<\mathrm{Al}_{2} \mathrm{O}_{3} \mathrm{wt} \%<5.4 \\
3.4<\mathrm{MgO} \text { wt } \%<5.1 \\
0.51<\mathrm{X}^{\prime} \text { usp }<0.63\end{array}$ & $\begin{array}{c}20.5<\mathrm{TiO}_{2} \mathrm{wt} \%<22.9 \\
0.3<\mathrm{Al}_{2} \mathrm{O}_{3} \mathrm{wt} \%<1.9 \\
0.3<\mathrm{MgO}^{\mathrm{wt} \%}<3.0 \\
0.48<\mathrm{X}^{\prime} \text { usp }<0.64\end{array}$ & $\begin{array}{c}21.2<\mathrm{TiO}_{2} \mathrm{wt} \%<23.2 \\
1.5<\mathrm{Al}_{2} \mathrm{O}_{3} \mathrm{wt} \%<2.8 \\
1.7<\mathrm{MgO} \text { wt } \%<3.2 \\
0.55<\mathrm{X}^{\prime} \text { usp }<0.70\end{array}$ \\
\hline $\mathrm{Ilm}$ & & $\begin{array}{c}\text { X'ilm }=0.93 \\
\mathrm{Fe}^{3+} / \mathrm{Fe}^{2+}=0.15\end{array}$ & \\
\hline Px & $\begin{array}{c}37.2<\mathrm{XMg} \%<43.4 \\
10.6<\mathrm{XFet}+\mathrm{Mn} \%<17.5 \\
41.3<\mathrm{XCa} \%<46.7\end{array}$ & $\begin{array}{c}37.3<\mathrm{XMg} \%<42.4 \\
14.5<\mathrm{XFet}+\mathrm{Mn} \%<21.8 \\
40.7<\mathrm{XCa} \%<45.2\end{array}$ & $\begin{array}{c}35.1<\mathrm{XMg} \%<36.8 \\
19.2<\mathrm{XFet}+\mathrm{Mn} \%<21.2 \\
43.7<\mathrm{XCa} \%<44.8\end{array}$ \\
\hline $\mathrm{F}$ & An $62-52$ & An $55-45$ & $\begin{array}{c}\text { An } 47-32 \\
\text { An } 11-6, \text { Or } 32-46 \\
\end{array}$ \\
\hline
\end{tabular}


Table 4. Selected chemical analyses of minerals. A, Olivine

\section{Manengouba, stage 1}

\begin{tabular}{|c|c|c|c|c|c|c|}
\hline \# & MA2b & CT45 & CT45 & CT45 & ML2 & ML2 \\
\hline $\begin{array}{l}\text { Petrographical } \\
\text { facies }\end{array}$ & Bs & alk-B & alk-B & alk-B & $\mathrm{H}$ & $\mathrm{H}$ \\
\hline Mineral type & xenocryst & phenocryst & microcryst & microcryst & xenocryst & phese \\
\hline $\mathrm{SiO}_{2}$ & 40.82 & 39.09 & 38.20 & 38.92 & 40.39 & 39.45 \\
\hline $\mathrm{TiO}_{2}$ & 0.04 & 0.00 & 0.05 & 0.08 & 0.03 & 0.03 \\
\hline $\mathrm{Al}_{2} \mathrm{O}_{3}$ & 0.03 & 0.00 & 0.00 & 0.00 & 0.08 & 0.04 \\
\hline $\mathrm{FeO}$ & 14.29 & 16.87 & 19.32 & 21.98 & 14.86 & 19.66 \\
\hline $\mathrm{MnO}$ & 0.19 & 0.27 & 0.47 & 0.52 & 0.22 & 0.27 \\
\hline $\mathrm{MgO}$ & 46.81 & 42.79 & 40.21 & 39.13 & 46.13 & 42.00 \\
\hline $\mathrm{CaO}$ & 0.30 & 0.19 & 0.16 & 0.28 & 0.23 & 0.22 \\
\hline $\mathrm{NiO}$ & & 0.08 & 0.00 & 0.42 & & \\
\hline Total & 102.48 & 99.29 & 98.41 & 101.33 & 101.94 & 101.67 \\
\hline $\mathrm{Si}$ & 0.996 & 0.999 & 0.998 & 1.000 & 0.994 & 0.995 \\
\hline $\mathrm{Ti}$ & 0.001 & 0.000 & 0.001 & 0.002 & 0.001 & 0.001 \\
\hline $\mathrm{Al}$ & 0.001 & 0.000 & 0.000 & 0.000 & 0.002 & 0.001 \\
\hline $\mathrm{Fe}^{2+}$ & 0.292 & 0.360 & 0.422 & 0.472 & 0.306 & 0.415 \\
\hline $\mathrm{Mn}$ & 0.004 & 0.006 & 0.010 & 0.011 & 0.005 & 0.006 \\
\hline $\mathrm{Mg}$ & 1.702 & 1.630 & 1.566 & 1.498 & 1.692 & 1.580 \\
\hline $\mathrm{Ca}$ & 0.008 & 0.005 & 0.004 & 0.008 & 0.006 & 0.006 \\
\hline $\mathrm{Ni}$ & 0.000 & 0.002 & 0.000 & 0.009 & 0.000 & 0.000 \\
\hline Total & 3.003 & 3.001 & 3.001 & 2.999 & 3.005 & 3.003 \\
\hline$\% \mathrm{Fo}$ & & 81.65 & 78.36 & 75.60 & 84.50 & 78.97 \\
\hline$\% \mathrm{Fa}$ & 14.79 & 18.35 & 21.64 & 24.40 & 15.50 & 21.03 \\
\hline
\end{tabular}


Table 4. Selected analyses of minerals. B, Magnetite

\section{Manengouba, stage 1}

\# $\quad$ MA2b $\quad$ MA2b $\quad$ ML2 $\quad$ ML2

Petrographical facies

$\begin{array}{llll}\text { Bs } & \text { Bs } & \mathrm{H} & \mathrm{H}\end{array}$

Mineral type phenocryst microcryst phenocryst microcryst

$\begin{array}{lccccccc}\mathrm{SiO}_{2} & 0.01 & 0.00 & 0.05 & 0.03 & 0.02 & 0.05 & 0.04 \\ \mathrm{TiO}_{2} & 17.51 & 18.59 & 20.85 & 19.25 & 17.23 & 16.21 & 17.11 \\ \mathrm{Al}_{2} \mathrm{O}_{3} & 4.83 & 4.15 & 5.17 & 2.30 & 1.83 & 2.47 & 2.02 \\ \mathrm{Cr}_{2} \mathrm{O}_{3} & 0.03 & 0.03 & 0.08 & 0.06 & 0.02 & 0.12 & 0.01 \\ \mathrm{FeO} & 69.24 & 68.05 & 67.73 & 73.12 & 73.75 & 77.34 & 75.59 \\ \mathrm{MnO} & 0.56 & 0.38 & 0.50 & 0.71 & 0.46 & 0.67 & 0.85 \\ \mathrm{MgO} & 6.25 & 6.55 & 4.54 & 1.78 & 2.22 & 1.16 & 0.47 \\ \mathrm{Total} & 98.43 & 97.75 & 98.92 & 97.25 & 95.51 & 98.02 & 96.09 \\ & & & & & & & \\ \mathrm{Si} & 0.003 & 0.000 & 0.014 & 0.009 & 0.004 & 0.015 & 0.012 \\ \mathrm{Al} & 1.578 & 1.367 & 1.706 & 0.797 & 0.642 & 0.850 & 0.715 \\ \mathrm{Ti} & 3.650 & 3.906 & 4.390 & 4.254 & 3.862 & 3.558 & 3.863 \\ \mathrm{Fe} & 7.111 & 6.814 & 5.468 & 6.664 & 7.621 & 7.977 & 7.532 \\ \mathrm{Fe} & 8.939 & 9.088 & 10.391 & 11.306 & 10.766 & 10.902 & 11.449 \\ \mathrm{Mg} & 2.582 & 2.728 & 1.895 & 0.780 & 0.986 & 0.505 & 0.210 \\ \mathrm{Mn} & 0.131 & 0.090 & 0.119 & 0.177 & 0.115 & 0.166 & 0.216 \\ \mathrm{Cr} & 0.007 & 0.007 & 0.018 & 0.014 & 0.004 & 0.028 & 0.002 \\ \mathrm{Total} & 24.000 & 24.000 & 24.000 & 24.000 & 24.000 & 24.000 & 24.000\end{array}$

\section{Manengouba, stage 2}

NS2 Eb11 Eb11

$\mathrm{H} \quad \mathrm{M}$

phenocryst phenocryst microcryst 
Table 4. Selected analyses of minerals. C, Ilmenite

Manengouba, stage 2

\begin{tabular}{|c|c|c|c|c|c|c|}
\hline$\#$ & NS2 & EB30 & Eb11 & Eb11 & EL4 & Eb17 \\
\hline $\begin{array}{l}\text { Petrographica } \\
1 \text { facies }\end{array}$ & $\mathrm{H}$ & M & M & M & $\mathrm{Bn}$ & \\
\hline Mineral type & microcryst & phenocryst & phenocryst & microcryst & phenocryst & microcry: \\
\hline $\mathrm{SiO}_{2}$ & 0.00 & 0.00 & 0.00 & 0.00 & 0.00 & 00 \\
\hline $\mathrm{TiO}_{2}$ & 49.71 & 50.17 & 49.66 & 48.22 & 48.92 & 51.12 \\
\hline $\mathrm{Al}_{2} \mathrm{O}_{3}$ & 0.36 & 0.14 & 0.20 & 0.43 & 0.47 & 0.04 \\
\hline $\mathrm{Cr}_{2} \mathrm{O}_{3}$ & 0.00 & 0.00 & 0.03 & 0.00 & 0.00 & 0.00 \\
\hline $\mathrm{FeO}$ & 41.92 & 42.46 & 45.39 & 48.20 & 44.44 & 44.69 \\
\hline $\mathrm{MnO}$ & 0.63 & 0.77 & 0.94 & 0.81 & 0.64 & 1.38 \\
\hline $\mathrm{MgO}$ & 4.89 & 4.01 & 3.42 & 1.81 & 5.45 & 0.86 \\
\hline $\mathrm{CaO}$ & 0.03 & 0.03 & 0.03 & 0.03 & 0.05 & 0.05 \\
\hline Total & 97.54 & 97.58 & 99.67 & 99.50 & 99.97 & 98.14 \\
\hline $\mathrm{Si}$ & 0.000 & 0.000 & 0.000 & 0.000 & 0.000 & 0.000 \\
\hline $\mathrm{Al}$ & 0.021 & 0.008 & 0.012 & 0.025 & 0.027 & 0.002 \\
\hline $\mathrm{Ti}$ & 1.854 & 1.885 & 1.834 & 1.804 & 1.770 & 1.962 \\
\hline $\mathrm{Fe}^{3+}$ & 0.263 & 0.218 & 0.315 & 0.359 & 0.424 & 0.072 \\
\hline $\mathrm{Fe}^{2+}$ & 1.476 & 1.556 & 1.549 & 1.647 & 1.364 & 1.836 \\
\hline $\mathrm{Mg}$ & 0.361 & 0.299 & 0.250 & 0.134 & 0.391 & 0.065 \\
\hline $\mathrm{Mn}$ & 0.026 & 0.033 & 0.039 & 0.034 & 0.026 & 0.060 \\
\hline $\mathrm{Cr}$ & 0.000 & 0.000 & 0.001 & 0.000 & 0.000 & 0.000 \\
\hline $\mathrm{Ca}$ & 0.001 & 0.002 & 0.002 & 0.002 & 0.003 & 0.003 \\
\hline Total & 4.002 & 4.000 & 4.001 & 4.003 & 4.002 & 3.998 \\
\hline
\end{tabular}

Manengouba, stage 3

phenocryst microcryst

$0.000 \quad 0.000$ 
Table 4. Selected analyses of minerals. D, Pyroxenes

\section{Manengouba, stage 1}

\begin{tabular}{|c|c|c|c|c|c|c|}
\hline \# & MA2B & MA2B & MA2B & MA2B & MA2B & ML2 \\
\hline $\begin{array}{l}\text { Petrographical } \\
\text { facies }\end{array}$ & $\mathrm{Na}-\mathrm{Bs}$ & $\mathrm{Na}-\mathrm{Bs}$ & $\mathrm{Na}-\mathrm{Bs}$ & $\mathrm{Na}-\mathrm{Bs}$ & $\mathrm{Na}-\mathrm{Bs}$ & \\
\hline Mineral type & xenocryst & phenocryst & phenocryst & microcryst & microcryst & \\
\hline $\mathrm{SiO}_{2}$ & 47.39 & 48.98 & 49.27 & 50.27 & 52.45 & 47.45 \\
\hline $\mathrm{TiO}_{2}$ & 2.27 & 2.03 & 2.02 & 1.06 & 0.77 & 2.12 \\
\hline $\mathrm{Al}_{2} \mathrm{O}_{3}$ & 7.13 & 5.49 & 4.75 & 3.37 & 1.90 & 5.87 \\
\hline $\mathrm{FeO}$ & 8.17 & 8.18 & 8.10 & 8.33 & 10.58 & 7.84 \\
\hline $\mathrm{Cr}_{2} \mathrm{O}_{3}$ & 0.04 & 0.00 & 0.18 & 0.00 & 0.00 & 0.04 \\
\hline $\mathrm{MnO}$ & 0.17 & 0.16 & 0.20 & 0.27 & 0.56 & 0.26 \\
\hline $\mathrm{MgO}$ & 13.86 & 14.25 & 14.62 & 15.16 & 13.93 & 13.94 \\
\hline $\mathrm{CaO}$ & 21.44 & 21.03 & 21.25 & 18.65 & 20.94 & 21.59 \\
\hline $\mathrm{Na}_{2} \mathrm{O}$ & 0.65 & 0.70 & 0.33 & 0.56 & 0.52 & 0.57 \\
\hline $\mathrm{K}_{2} \mathrm{O}$ & 0.01 & 0.00 & 0.00 & 0.00 & 0.02 & 0.00 \\
\hline Total & 101.13 & 100.82 & 100.72 & 97.66 & 101.67 & 99.68 \\
\hline $\mathrm{Si}$ & 1.733 & 1.796 & 1.814 & 1.899 & 1.928 & 1.761 \\
\hline $\mathrm{Al}^{\mathrm{IV}}$ & 0.267 & 0.204 & 0.186 & 0.101 & 0.072 & 0.239 \\
\hline $\mathrm{T}$ & 2.000 & 2.000 & 2.000 & 2.000 & 2.000 & 2.000 \\
\hline $\mathrm{Al}^{\mathrm{VI}}$ & 0.040 & 0033 & 0.020 & 0.049 & 0.010 & 0.018 \\
\hline $\mathrm{Ti}^{\mathrm{VI}}$ & 0.062 & 0.056 & 0.056 & 0.030 & 0.021 & 0.059 \\
\hline $\mathrm{Fe}^{3+}$ & 0.147 & 0.108 & 0.073 & 0.032 & 0.057 & 0.141 \\
\hline $\mathrm{Cr}$ & 0.001 & 0.000 & 0.005 & 0.000 & 0.000 & 0.001 \\
\hline $\mathrm{Fe}^{2+}$ & 0.090 & 0.125 & 0.152 & 0.189 & 0.237 & 0.091 \\
\hline $\mathrm{Mg}$ & 0.660 & 0.678 & 0.694 & 0.699 & 0.675 & 0.689 \\
\hline M1 & 1.000 & 1.000 & 1.000 & 1.000 & 1.000 & 1.000 \\
\hline $\mathrm{Fe} 2+$ & 0.013 & 0.019 & 0.024 & 0.042 & 0.031 & 0.011 \\
\hline $\mathrm{Mg}$ & 0.096 & 0.101 & 0.108 & 0.154 & 0.089 & 0.082 \\
\hline $\mathrm{Mn}$ & 0.005 & 0.005 & 0.006 & 0.009 & 0.017 & 0.008 \\
\hline $\mathrm{Ca}$ & 0.840 & 0.826 & 0.838 & 0.755 & 0.825 & 0.859 \\
\hline $\mathrm{Na}$ & 0.046 & 0.050 & 0.024 & 0.041 & 0.037 & 0.041 \\
\hline $\mathrm{K}$ & 0.000 & 0.000 & 0.000 & 0.000 & 0.001 & 0.000 \\
\hline M2 & 1.001 & 1.000 & 1.000 & 1.000 & 1.000 & 1.001 \\
\hline $\mathrm{Mg} \%$ & 44.34 & 44.42 & 44.01 & 46.19 & 40.74 & 44.33 \\
\hline
\end{tabular}


Table 4. Selected analyses of minerals. E, Amphibole

Manengouba, stage 2

\begin{tabular}{|c|c|c|c|c|c|}
\hline \# & EB11 & Eb10 & Eb10 & Eb10 & EK1C \\
\hline $\begin{array}{l}\text { Petrographical } \\
\text { facies }\end{array}$ & M & M & M & M & $\mathrm{H}$ \\
\hline \multirow[t]{2}{*}{ Mineral type } & nicrophenocrys & phenocryst & phenocryst & phenocryst & phenocryst \\
\hline & Edenite & Kaersutite & Kaersutite & Kaersutite & Kaersutite \\
\hline $\mathrm{SiO}_{2}$ & 45.40 & 40.84 & 40.24 & 39.59 & 3 \\
\hline $\mathrm{TiO}_{2}$ & 2.10 & 6.03 & 5.85 & 6.16 & 5.20 \\
\hline $\mathrm{Al}_{2} \mathrm{O}_{3}$ & 6.71 & 13.03 & 12.34 & 13.65 & 12.85 \\
\hline $\mathrm{Cr}_{2} \mathrm{O}_{3}$ & 0.00 & 0.02 & 0.00 & 0.05 & 0.00 \\
\hline $\mathrm{FeO}$ & 10.66 & 11.24 & 11.11 & 10.63 & 11.55 \\
\hline $\mathrm{MnO}$ & 0.39 & 0.21 & 0.22 & 0.17 & 0.12 \\
\hline $\mathrm{MgO}$ & 16.42 & 12.25 & 13.12 & 12.09 & 13.10 \\
\hline $\mathrm{CaO}$ & 10.45 & 11.65 & 11.77 & 11.96 & 11.77 \\
\hline $\mathrm{Na}_{2} \mathrm{O}$ & 2.88 & 2.69 & 3.14 & 2.81 & 2.90 \\
\hline $\mathrm{K}_{2} \mathrm{O}$ & 1.17 & 0.88 & 0.89 & 0.95 & 1.02 \\
\hline Total & 96.17 & 98.84 & 98.68 & 98.06 & 98.05 \\
\hline $\mathrm{Si}$ & 6.661 & 5.993 & 5.930 & 5.888 & 5.847 \\
\hline $\mathrm{Al}^{\mathrm{IV}}$ & 1.160 & 2.007 & 2.070 & 2.112 & 2.153 \\
\hline $\mathrm{Ti}$ & 0.179 & 0.000 & 0.000 & 0.000 & 0.000 \\
\hline Total & 8.000 & 8.000 & 8.000 & 8.000 & 8.000 \\
\hline $\mathrm{Al}^{\mathrm{VI}}$ & 0.000 & 0.247 & 0.073 & 0.281 & 0.088 \\
\hline $\mathrm{Ti}$ & 0.053 & 0.665 & 0.648 & 0.689 & 0.579 \\
\hline $\mathrm{Cr}$ & 0.000 & 0.002 & 0.000 & 0.006 & 0.000 \\
\hline $\mathrm{Fe}^{3+}$ & 0.721 & 0.000 & 0.000 & 0.000 & 0.152 \\
\hline $\mathrm{Fe}^{2+}$ & 0.586 & 1.379 & 1.369 & 1.322 & 1.277 \\
\hline $\mathrm{Mn}$ & 0.049 & 0.026 & 0.027 & 0.021 & 0.015 \\
\hline $\mathrm{Mg}$ & 3.591 & 2.680 & 2.882 & 2.680 & 2.889 \\
\hline Total & 5.000 & 5.000 & 5.000 & 5.000 & 5.000 \\
\hline $\mathrm{Ca}$ & 1.642 & 1.832 & 1.858 & 1.906 & 1.865 \\
\hline $\mathrm{Na}$ & 0.358 & 0.168 & 0.142 & 0.094 & 0.135 \\
\hline Total & 2.000 & 2.000 & 2.000 & 2.000 & 2.000 \\
\hline $\mathrm{Na}$ & 0.461 & 0.597 & 0.756 & 0.716 & 0.697 \\
\hline K & 0.218 & 0.165 & 0.167 & 0.180 & 0.193 \\
\hline Total & 0.679 & 0.762 & 0.923 & 0.896 & 0.890 \\
\hline
\end{tabular}

Manengouba, EK1C H phenocryst 
Table 4. Selected analyses of minerals. F, Mica

\section{Manengouba, stage 2}

Eb11 Eb11

\#
Petrographical facies

Mineral type phenocryst phenocryst

$\mathrm{SiO}_{2}$

$\mathrm{Al}_{2} \mathrm{O}_{3}$

$\mathrm{Cr}_{2} \mathrm{O}_{3}$

$\mathrm{FeO}$

$\mathrm{MgO}$

$\mathrm{CaO}$

$\mathrm{MnO}$

$\mathrm{Na}_{2} \mathrm{O}$

$\mathrm{K}_{2} \mathrm{O}$

Total

$\mathrm{Si}$

$\mathrm{Al}^{\mathrm{IV}}$

Total

$\mathrm{Al}^{\mathrm{VI}}$

Ti

$\mathrm{Fe}$

$\mathrm{Mg}$

$\mathrm{Mn}$

Total

K

$\mathrm{Na}$

Total

$\begin{array}{cc}40.56 & 41.02 \\ 3.92 & 3.90 \\ 12.33 & 11.88 \\ 0.00 & 0.11 \\ 9.56 & 8.97 \\ 20.59 & 20.61 \\ 0.08 & 0.00 \\ 0.11 & 0.00 \\ 0.99 & 0.84 \\ 9.00 & 9.31 \\ 97.14 & 96.64\end{array}$

3.152

3.196

0.848

0.804

4.000

4.000

0.282

0.287

0.229

0.584

2.394

0.000

0.007

3.493

0.927

0.894

0.127

1.054

1.044

Manengouba, stage 4

$\begin{array}{cc}\text { KOS7 } & \text { KOS7 } \\ \text { M } & \text { M }\end{array}$

microphenocrys microcryst

$\begin{array}{cc}39.60 & 39.27 \\ 4.99 & 5.74 \\ 11.97 & 12.36 \\ 0.00 & 0.00 \\ 9.51 & 10.02 \\ 19.60 & 18.54 \\ 0.01 & 0.03 \\ 0.13 & 0.11 \\ 1.40 & 1.02 \\ 8.49 & 8.60 \\ 95.70 & 95.69\end{array}$

$3.128 \quad 3.107$

$0.872 \quad 0.893$

$4.000 \quad 4.000$

$0.241 \quad 0.260$

$0.296 \quad 0.342$

$0.628 \quad 0.663$

$2.308 \quad 2.187$

$0.009 \quad 0.008$

$3.482 \quad 3.459$

$0.857 \quad 0.870$

$0.215 \quad 0.156$

$1.072 \quad 1.026$ 
Table 4. Selected analyses of minerals. G, Feldspars

\section{Manengouba, stage 1}

\begin{tabular}{|c|c|c|c|c|c|c|}
\hline \# & CT46 & MA2B & MA2B & MA2B & MA2B & MA2B \\
\hline $\begin{array}{l}\text { etrographical } \\
\text { cies }\end{array}$ & alk-B & $\mathrm{Na}-\mathrm{Bs}$ & $\mathrm{Na}-\mathrm{Bs}$ & $\mathrm{Na}-\mathrm{Bs}$ & $\mathrm{Na}-\mathrm{Bs}$ & $\mathrm{Na}-\mathrm{Bs}$ \\
\hline
\end{tabular}

Mineral type phenocryst phenocryst phenocryst microcryst microcryst xenocryst phenocryst

$\begin{array}{lccccccc}\mathrm{SiO}_{2} & 50.55 & 50.02 & 50.79 & 52.90 & 54.49 & 56.41 & 52.87 \\ \mathrm{Al}_{2} \mathrm{O}_{3} & 31.66 & 31.97 & 29.79 & 30.11 & 28.51 & 28.25 & 30.19 \\ \mathrm{Fe}_{2} \mathrm{O}_{3} & 1.05 & 0.98 & 0.82 & 0.93 & 0.53 & 0.43 & 0.33 \\ \mathrm{CaO} & 13.02 & 13.02 & 12.16 & 11.39 & 10.48 & 9.63 & 12.32 \\ \mathrm{Na}_{2} \mathrm{O} & 3.71 & 3.55 & 3.98 & 4.52 & 5.22 & 5.69 & 4.33 \\ \mathrm{~K}_{2} \mathrm{O} & 0.01 & 0.26 & 0.25 & 0.31 & 0.36 & 0.53 & 0.23 \\ \mathrm{Total} & 100.00 & 99.80 & 97.78 & 100.16 & 99.59 & 100.94 & 100.27 \\ & & & & & & & \\ \mathrm{Si} & 2.300 & 2.284 & 2.359 & 2.393 & 2.470 & 2.515 & 2.389 \\ \mathrm{Al} & 1.698 & 1.720 & 1.631 & 1.605 & 1.523 & 1.485 & 1.608 \\ \mathrm{Fe} & 0.036 & 0.034 & 0.029 & 0.032 & 0.018 & 0.014 & 0.011 \\ \mathrm{Ca} & 0.635 & 0.637 & 0.605 & 0.552 & 0.509 & 0.460 & 0.597 \\ \mathrm{Na} & 0.327 & 0.314 & 0.359 & 0.396 & 0.459 & 0.492 & 0.379 \\ \mathrm{~K} & 0.001 & 0.015 & 0.015 & 0.018 & 0.021 & 0.030 & 0.014 \\ \mathrm{Total} & 4.997 & 5.004 & 4.998 & 4.996 & 4.999 & 4.996 & 4.998 \\ \% \mathrm{Ab} & & & & & & & \\ \% \mathrm{An} & 34.00 & 32.52 & 36.64 & 41.02 & 46.41 & 50.08 & 38.34 \\ \% \text { Or } & 65.94 & 65.91 & 61.86 & 57.12 & 51.48 & 46.84 & 60.29 \\ & 0.06 & 1.57 & 1.49 & 1.86 & 2.11 & 3.08 & 1.37\end{array}$


Table 5. Chemical analyses of the rocks

\section{Manengouba, stage 1}

\begin{tabular}{|c|c|c|c|c|c|}
\hline Location & Ekon-Nkam fal] & Mantem & N Manjo & E Manjo & Enyandong \\
\hline & & & Mahongué river & Moo river & Mbe river \\
\hline \# & KO1 & CT46 & MA2B & ML2 & DN1 \\
\hline Setting type & flow & flow & flow & flow & flow \\
\hline $\begin{array}{l}\text { Petrographical } \\
\text { farisc }\end{array}$ & Ank & alk B & $\mathrm{Na}-\mathrm{Bs}$ & $\mathrm{H}$ & $\mathrm{Na}-\mathrm{H}$ \\
\hline $\mathrm{SiO}_{2}$ & 43.38 & 46.58 & 45.83 & 47.47 & 46.62 \\
\hline $\mathrm{TiO}_{2}$ & 2.61 & 2.47 & 2.71 & 2.67 & 2.75 \\
\hline $\mathrm{Al}_{2} \mathrm{O}_{3}$ & 13.10 & 15.14 & 15.03 & 16.17 & 17.13 \\
\hline $\mathrm{Fe}_{2} \mathrm{O}_{3} \mathrm{t}$ & 12.79 & 12.72 & 11.89 & 11.38 & 10.98 \\
\hline $\mathrm{MnO}$ & 0.17 & 0.17 & 0.17 & 0.18 & 0.18 \\
\hline $\mathrm{MgO}$ & 11.04 & 8.51 & 6.94 & 5.55 & 3.85 \\
\hline $\mathrm{CaO}$ & 10.67 & 8.19 & 9.94 & 9.15 & 9.30 \\
\hline $\mathrm{Na}_{2} \mathrm{O}$ & 2.66 & 2.67 & 3.24 & 3.83 & 4.47 \\
\hline $\mathrm{K}_{2} \mathrm{O}$ & 1.29 & 1.43 & 1.61 & 1.54 & 1.61 \\
\hline $\mathrm{P}_{2} \mathrm{O}_{5}$ & 0.61 & 0.62 & 0.65 & 0.77 & 0.88 \\
\hline LOI & 1.40 & 1.47 & 1.64 & 0.91 & 1.87 \\
\hline TOTAL & 99.72 & 99.97 & 99.65 & 99.62 & 99.64 \\
\hline DI & 24.37 & 31.88 & 33.80 & 39.33 & 42.20 \\
\hline $\mathrm{V}$ & 251 & 15 & 213 & 183 & 192 \\
\hline $\mathrm{Cr}$ & 399 & 318.7 & 236 & 128 & 39.0 \\
\hline Co & 49.3 & 45.02 & 36.3 & 29.4 & 24.0 \\
\hline $\mathrm{Ni}$ & 241.0 & 222.5 & 113.0 & 73.0 & 19.0 \\
\hline $\mathrm{Cu}$ & 68.93 & 61.06 & 46.95 & 40.89 & 23.37 \\
\hline $\mathrm{Ga}$ & 20.32 & 23.84 & 23.4 & 24.33 & 23.1 \\
\hline $\mathrm{Rb}$ & 35.00 & 32.91 & 52.00 & 36.00 & 35.00 \\
\hline $\mathrm{Sr}$ & 661.0 & 564.5 & 790.0 & 1027.0 & 808.0 \\
\hline $\mathrm{Y}$ & 23.30 & 48.29 & 26.70 & 30.10 & 31.80 \\
\hline $\mathrm{Zr}$ & 201.0 & 314.6 & 243.0 & 282.0 & 244.0 \\
\hline $\mathrm{Nb}$ & 57.82 & 58.37 & 68.43 & 75.02 & 58.9 \\
\hline $\mathrm{Ba}$ & 492.0 & 539.6 & 533.0 & 637.0 & 504.0 \\
\hline Hf & 4.00 & 6.84 & 6.03 & 6.23 & 5.53 \\
\hline $\mathrm{Ta}$ & 4.04 & 4.32 & 4.95 & 5.22 & 4.35 \\
\hline $\mathrm{Pb}$ & 2.17 & 2.79 & 3.89 & 3.02 & 2.75 \\
\hline $\mathrm{Th}$ & 4.60 & 4.84 & 6.77 & 6.87 & 4.40 \\
\hline $\mathrm{U}$ & 1.30 & 1.28 & 2.27 & 1.70 & 1.18 \\
\hline $\mathrm{La}$ & 40.05 & 58.87 & 61.17 & 68.12 & 49.28 \\
\hline $\mathrm{Ce}$ & 77.90 & 92.85 & 118.00 & 135.00 & 103.00 \\
\hline
\end{tabular}


Table 6

\section{Location}

Pre-Manengouba

NW borders

Essom

Bakossi

E-volc. substratum

NE-Nlonako

Manengouba

Ekom

Caldera

Eboga SE-floor

Eboga NW-floor

Flank activity

Mboassoum

W-Bangen

Ekoh

S-Mbouroukou
Isotopic data

\begin{tabular}{|c|c|c|c|c|c|c|c|c|c|c|c|c|c|c|c|}
\hline Sample & $\begin{array}{l}\text { Rock } \\
\text { type }\end{array}$ & $\begin{array}{l}\text { Age } \\
(\mathrm{Ma})\end{array}$ & $\mathbf{R b}$ & $\mathrm{Sr}$ & $\begin{array}{c}{ }^{87} \mathbf{S r} /{ }^{86} \mathbf{S r} \\
\pm 2 \sigma\end{array}$ & Sm & Nd & $\begin{array}{c}{ }^{143} \mathbf{N d} /{ }^{144} \mathbf{N d} \\
\pm 2 \sigma\end{array}$ & $\varepsilon \mathbf{N d}$ & $\mathbf{U}$ & Th & $\mathbf{P b}$ & ${ }^{006} \mathrm{~Pb} /{ }^{204} \mathrm{~Pb}$ & ${ }^{207} \mathrm{~Pb} /{ }^{204} \mathrm{~Pb}$ & ${ }^{208} \mathrm{~Pb} /{ }^{204} \mathrm{~Pb}$ \\
\hline CT-107 & $\mathrm{T}$ & 13.56 & 96.0 & 116 & $0.706216 \pm 5$ & 14.18 & 81.18 & $0.512558 \pm 11$ & -1.35 & 3.22 & 13.2 & & 18.45 & 15.59 & 38.85 \\
\hline CT-103 & $\mathrm{Ph}$ & 7.55 & 254 & 33.8 & $0.707574 \pm 6$ & 10.81 & 61.67 & $0.512756 \pm 5$ & 2.49 & & & & & & \\
\hline KBT 5 & $\mathrm{H}$ & 9.27 & 37 & 900 & $0.703326 \pm 7$ & 11.1 & 56.9 & $0.512910 \pm 12$ & 5.44 & & & & & & \\
\hline CT-155 & $\mathrm{Rh}$ & 1.02 & 200 & 6.2 & $0.708554 \pm 5$ & 4.04 & 17.0 & $0.512764 \pm 19$ & 2.47 & & & 77 & 18.79 & 15.60 & 39.04 \\
\hline KEB 19 & $\mathrm{H}$ & 0.28 & 50.9 & 616 & $0.703114 \pm 7$ & 9.28 & 46.3 & $0.512924 \pm 12$ & 5.58 & & & & & & \\
\hline KEB 33 & $\mathrm{H}$ & 0.14 & 36.0 & 524 & $0.703045 \pm 7$ & 7.42 & 35.0 & $0.512923 \pm 16$ & 5.56 & & & & & & \\
\hline CT-108 & $\mathrm{H}$ & 0.45 & 30.9 & 513 & $0.703055 \pm 7$ & 8.06 & 37.0 & $0.512948 \pm 10$ & 6.05 & 1.3 & 4.86 & 2.15 & 19.75 & 15.63 & 39.45 \\
\hline CT-105 & $\mathrm{T}-\mathrm{P}$ & 0.21 & 144 & 417 & $0.703042 \pm 9$ & 10.8 & 61.7 & $0.512869 \pm 22$ & 4.62 & 6.38 & 23.0 & 8.12 & 19.78 & 15.63 & 39.48 \\
\hline CT-55 & Bs & 0.11 & 43.9 & 957 & $0.703041 \pm 6$ & 10.4 & 55.4 & $0.512933 \pm 9$ & 5.76 & & & & & & \\
\hline KME 2a & $\mathrm{H}$ & 0.10 & 32.5 & 746 & $0.703083 \pm 6$ & 9.33 & 45.89 & $0.512917 \pm 16$ & 5.44 & & & & & & \\
\hline
\end{tabular}


Fig. 1

A

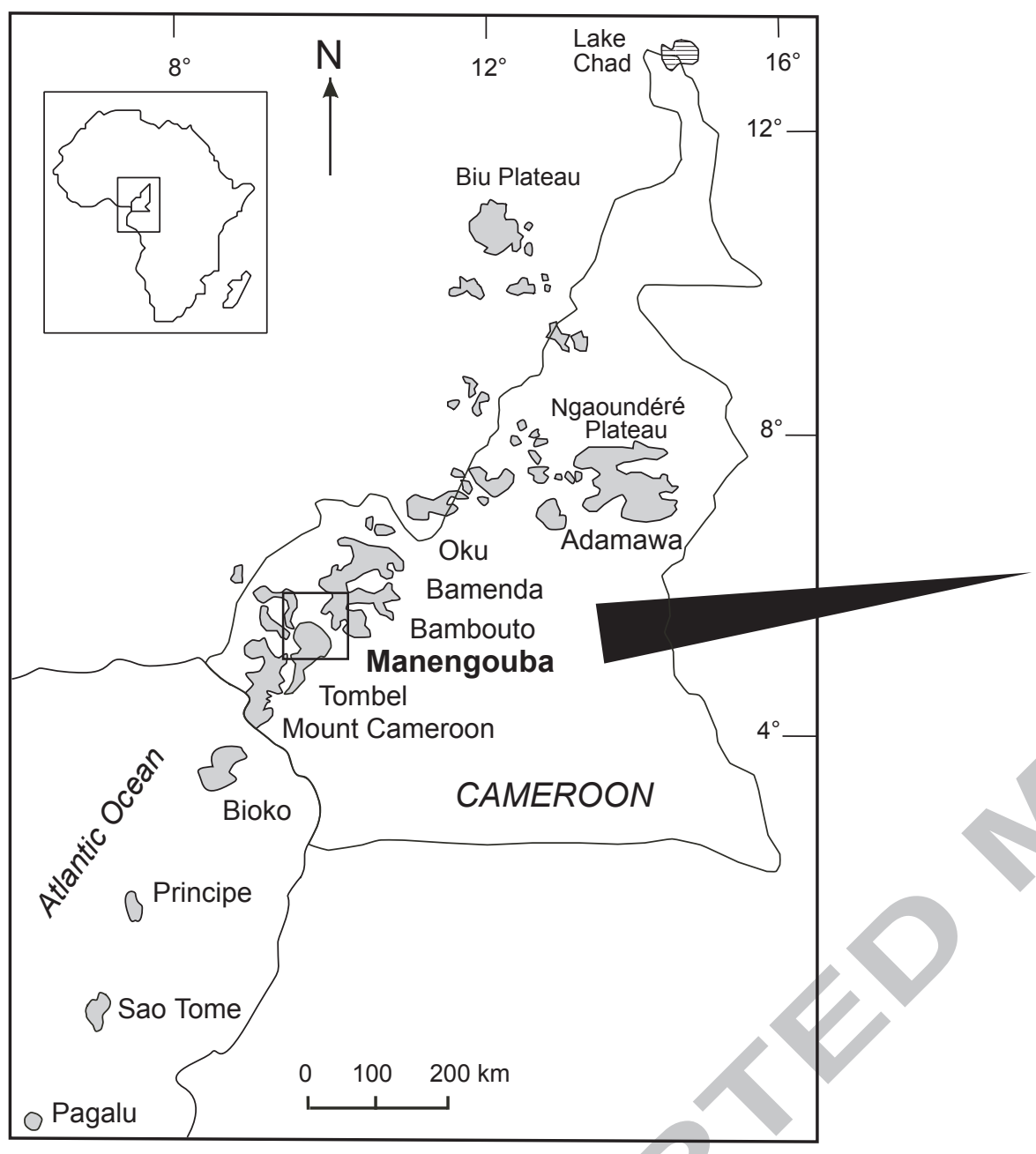

B

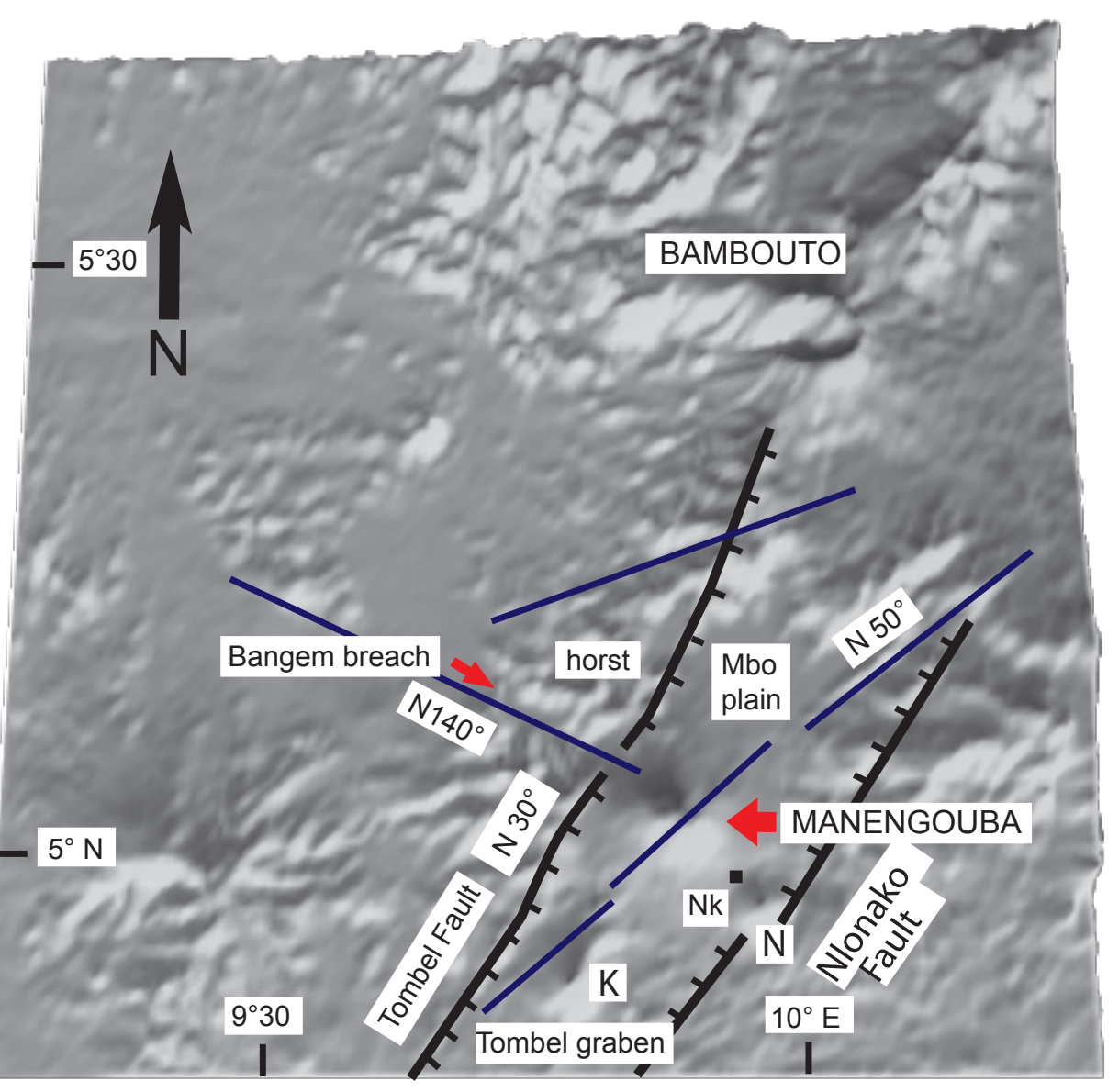

$50 \mathrm{~km}$ 


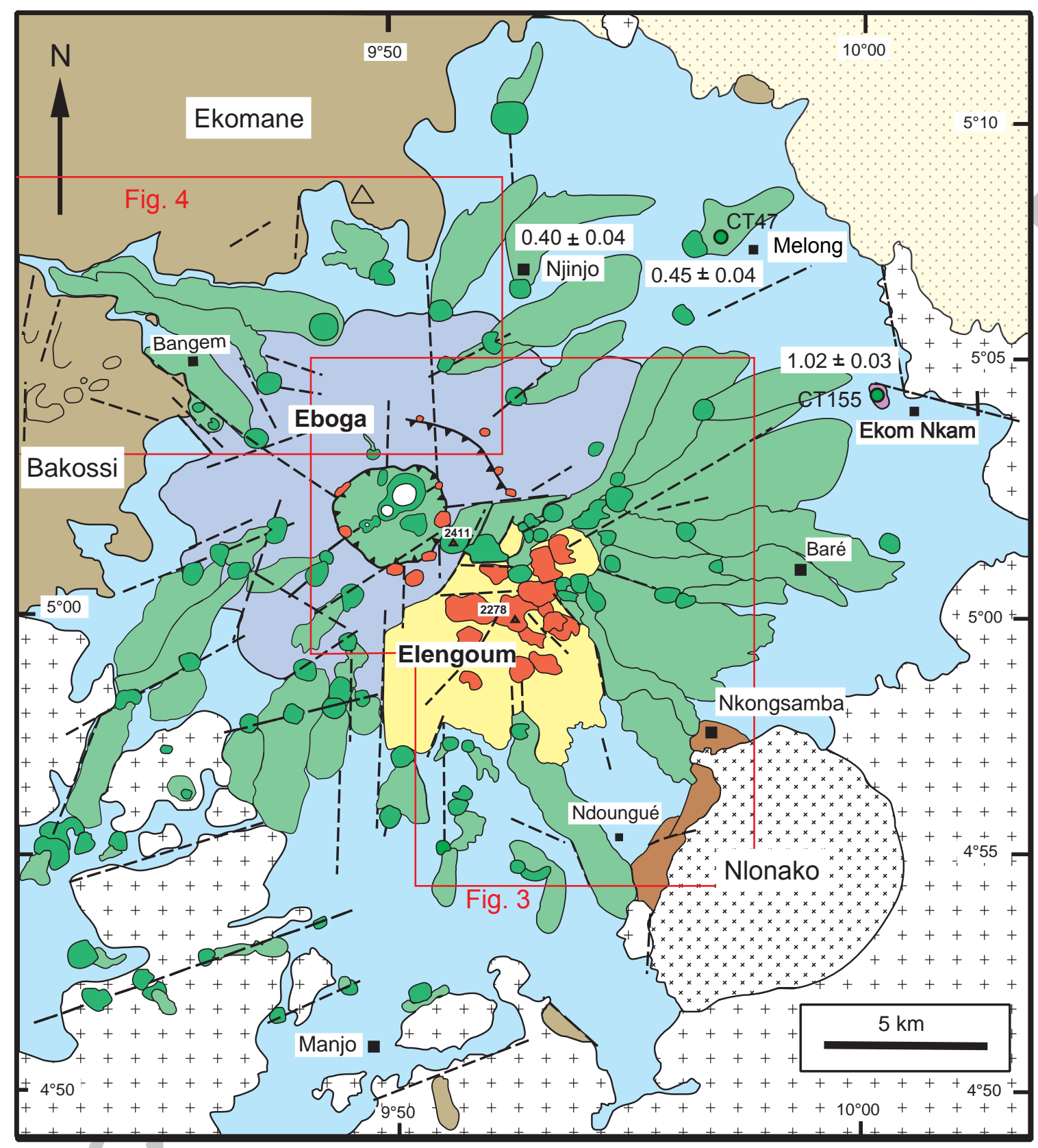

MANENGOUBA Volcanic System

1 - Early Manengouba shield volcano (1.55 - $0.94 \mathrm{Ma}$ )

2 - Eboga stratovolcano

hawaiite - mugearite - benmoreite flows

3 - Elengoum Extrusive Complex benmoreite and trachyte extrusions $(0.9-0.7 \mathrm{Ma})$

trachyte pyroclastic flows 4 - Flank volcanoes, cones and flows (0.5 - $0.1 \mathrm{Ma}$ )

\section{Unrelated lavas}

rhyolite of Ekom (1.02 Ma)
Pre-Manengouba lava flows (9 Ma)

North-western trachyte and phonolite of the Bakossi - Ekomane shield

(13.6 - 7.4 Ma) and of limited southern sites

$\left.\begin{array}{l}x^{x} x^{x} x^{x} \\ x_{x} x^{x} \times x\end{array}\right]$ Eocene syenite intrusion

++ Neoproterozoic granite basement

Quaternary sediments

Fault 


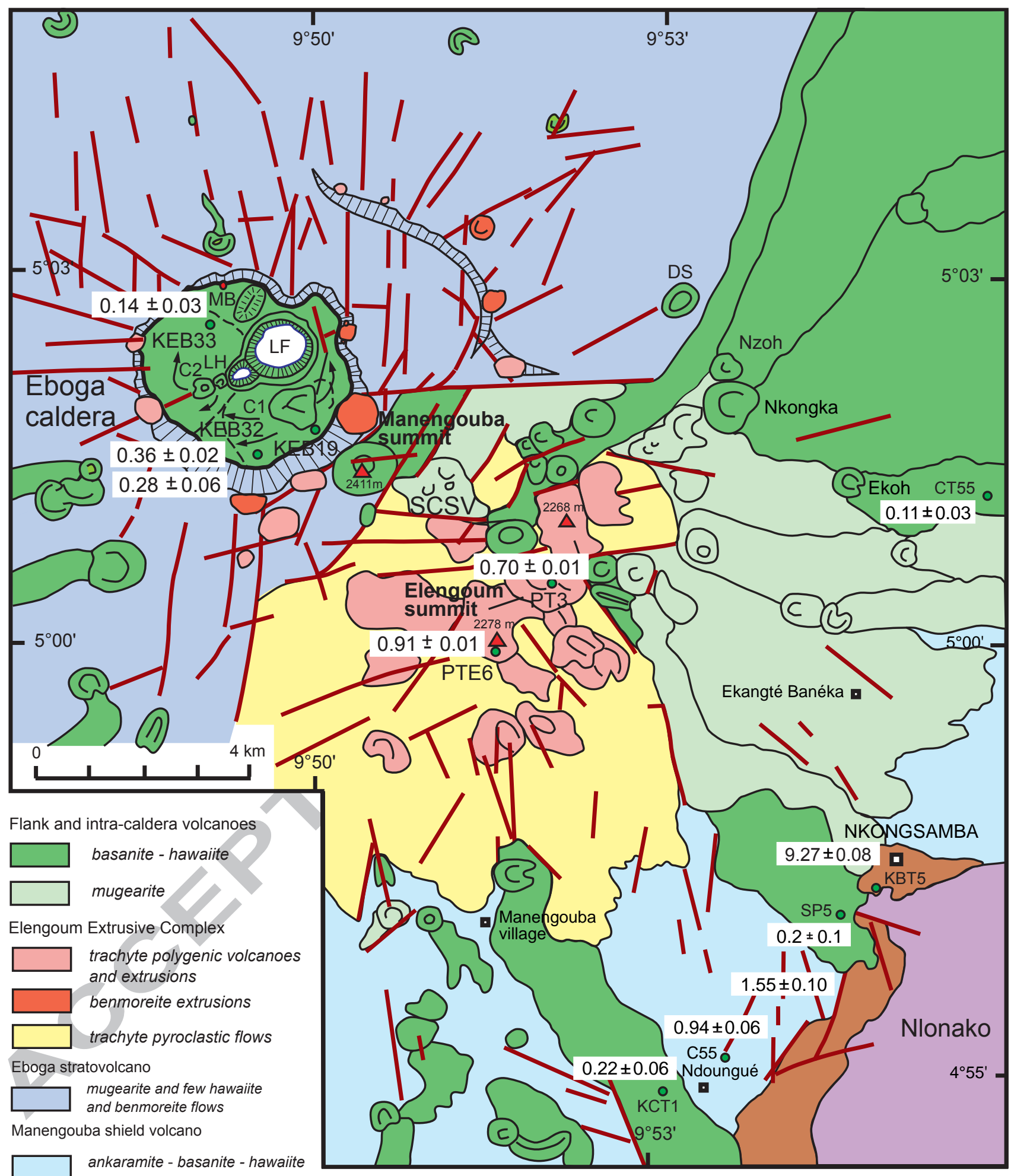

Pre-Manengouba lava flows

basanite - hawaiite - mugearite

Nlonako Massif

syenite - rhyolite

Fractures and faults

\begin{tabular}{l|l|l|l|l}
\hline & & & & Caldera wall and north-eastern
\end{tabular} scarp 
Fig. 4

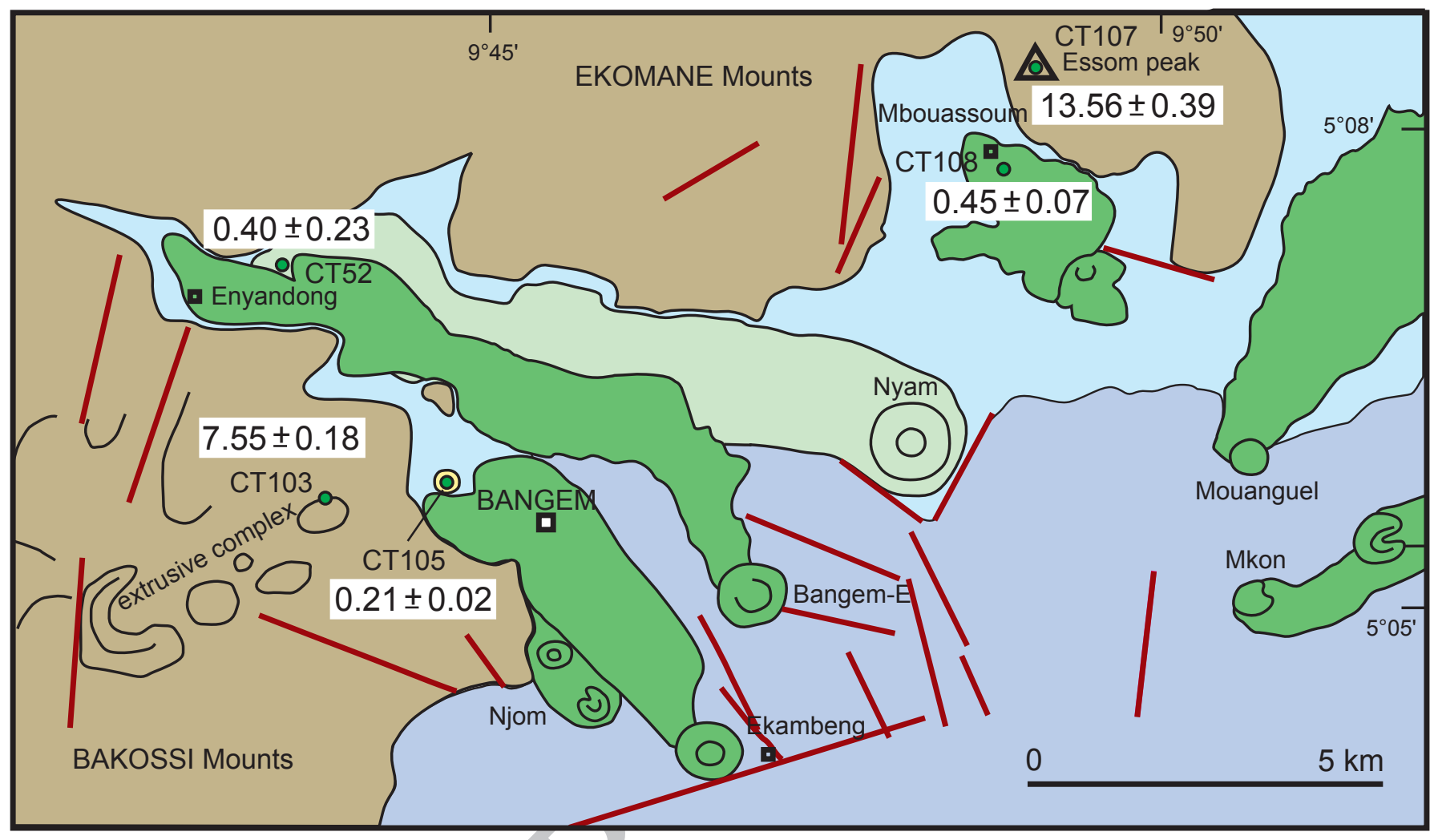

Flank volcanoes

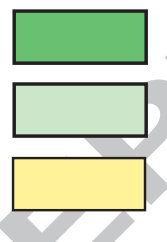

basanite - hawaiite mugearite trachy-phonolite

Eboga stratovolcano
Manengouba shield lava flows

basanite

Pre-Manengouba volcanic rocks trachyte - phonolite

hawaiite - mugearite benmoreite 

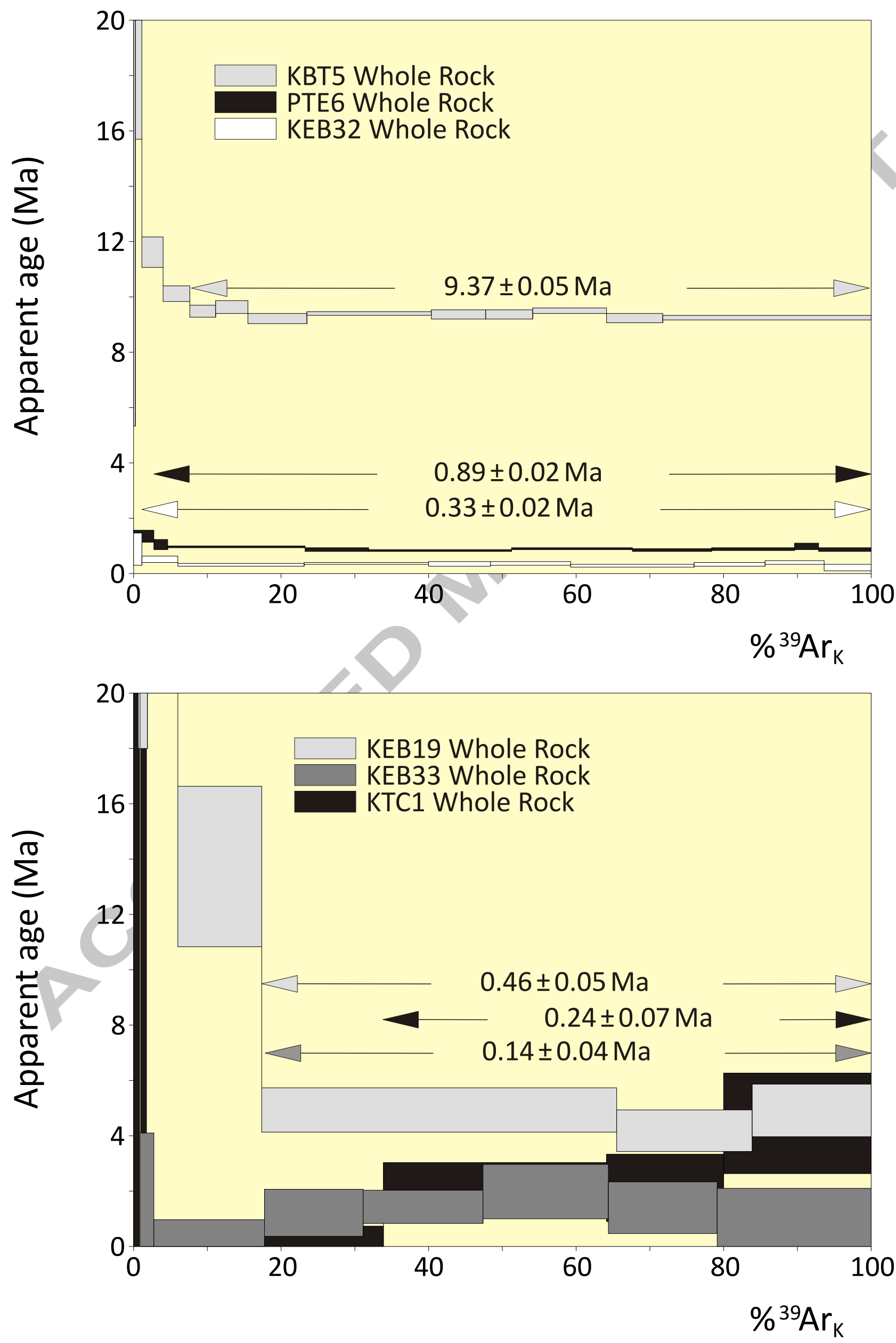
St 1 - Manengouba shield

St 2 - Eboga stratovolcano

St $3 a$ - Elengoum acidic extrusions and

Eboga caldera collapse

St $3 b$ - Acidic extrusions and caldera infilling

End of the first magmatic activity

St 4 - Renewal of the activity inside the caldera and on the flanks

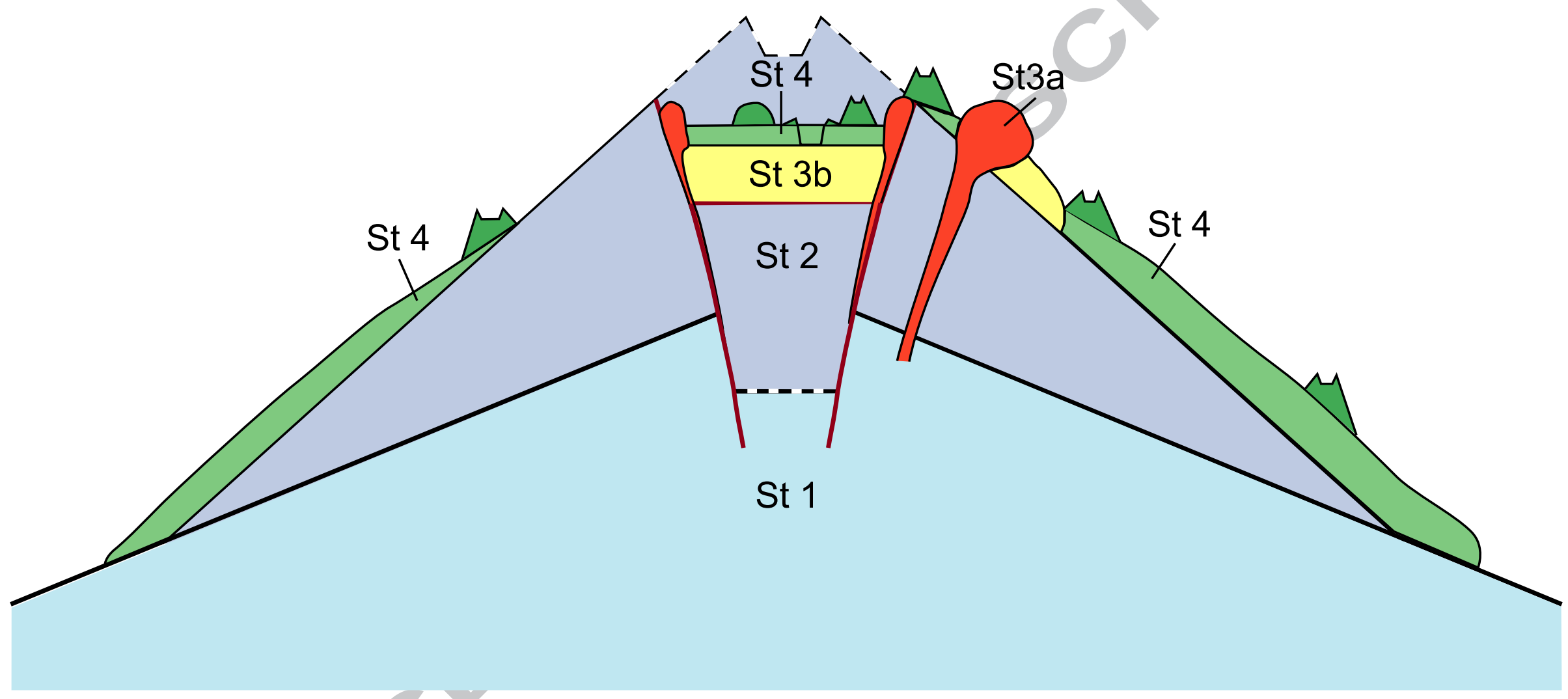


Fig. 7

\section{A}

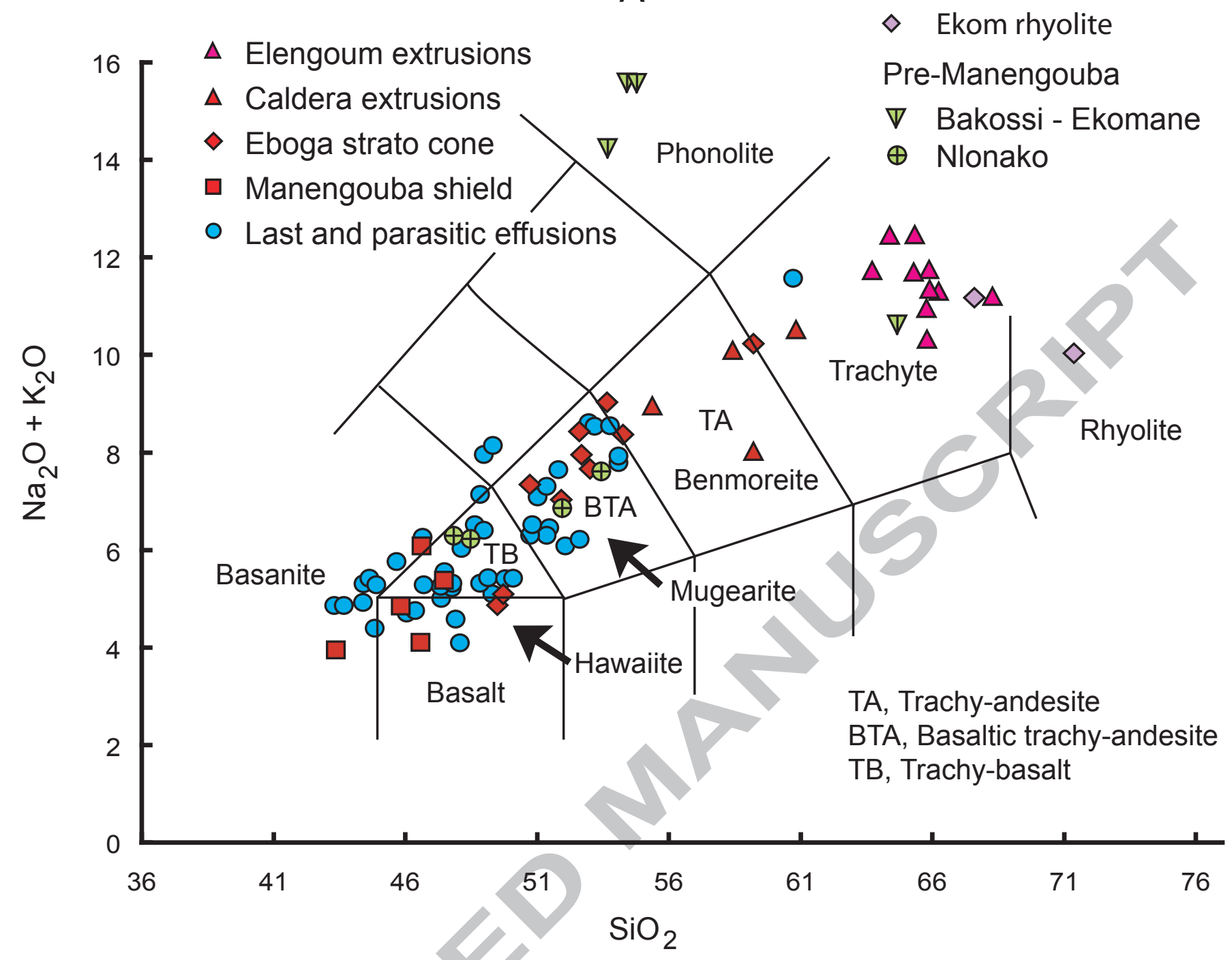

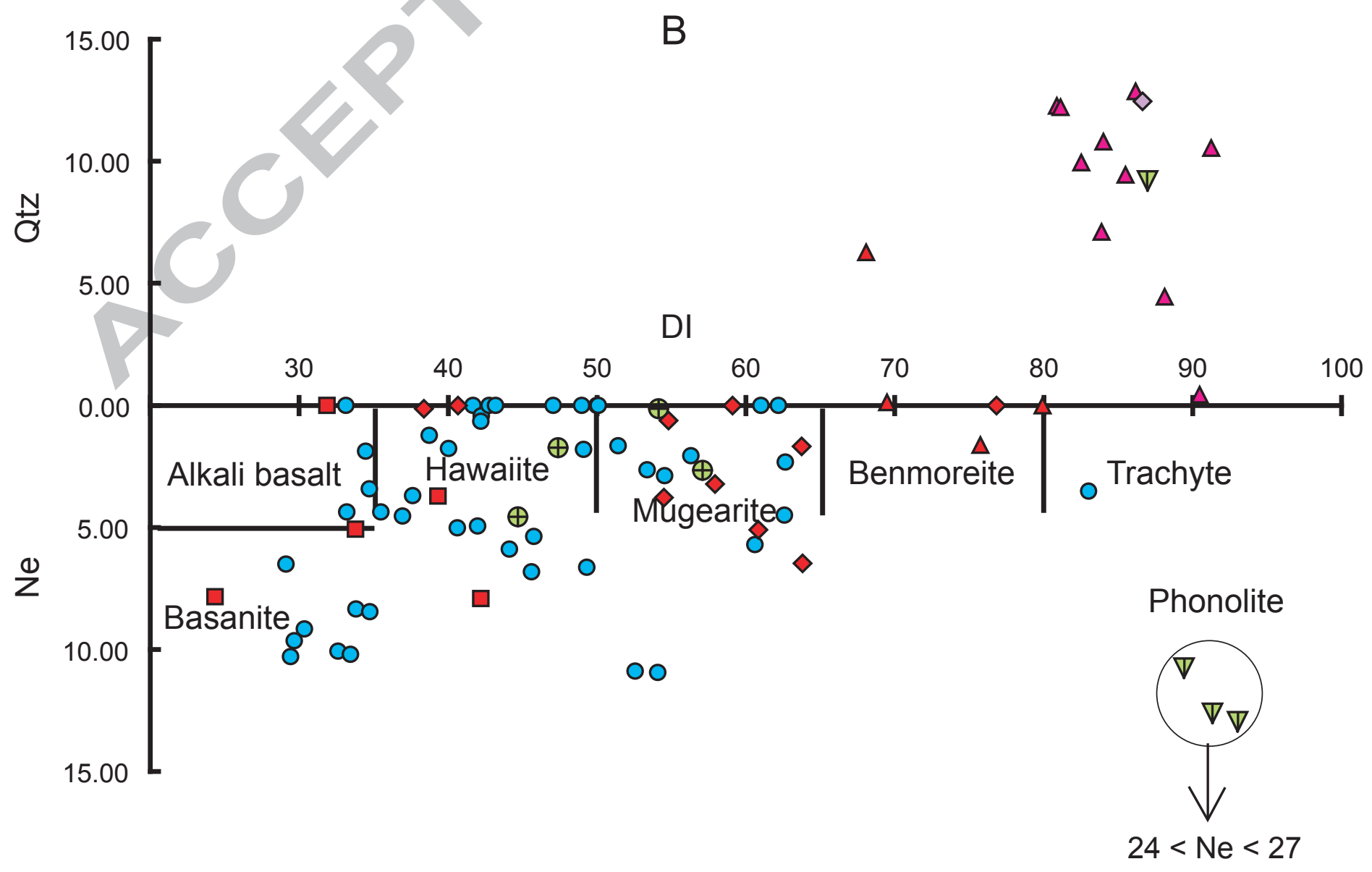


Fig. 8

A Group 1

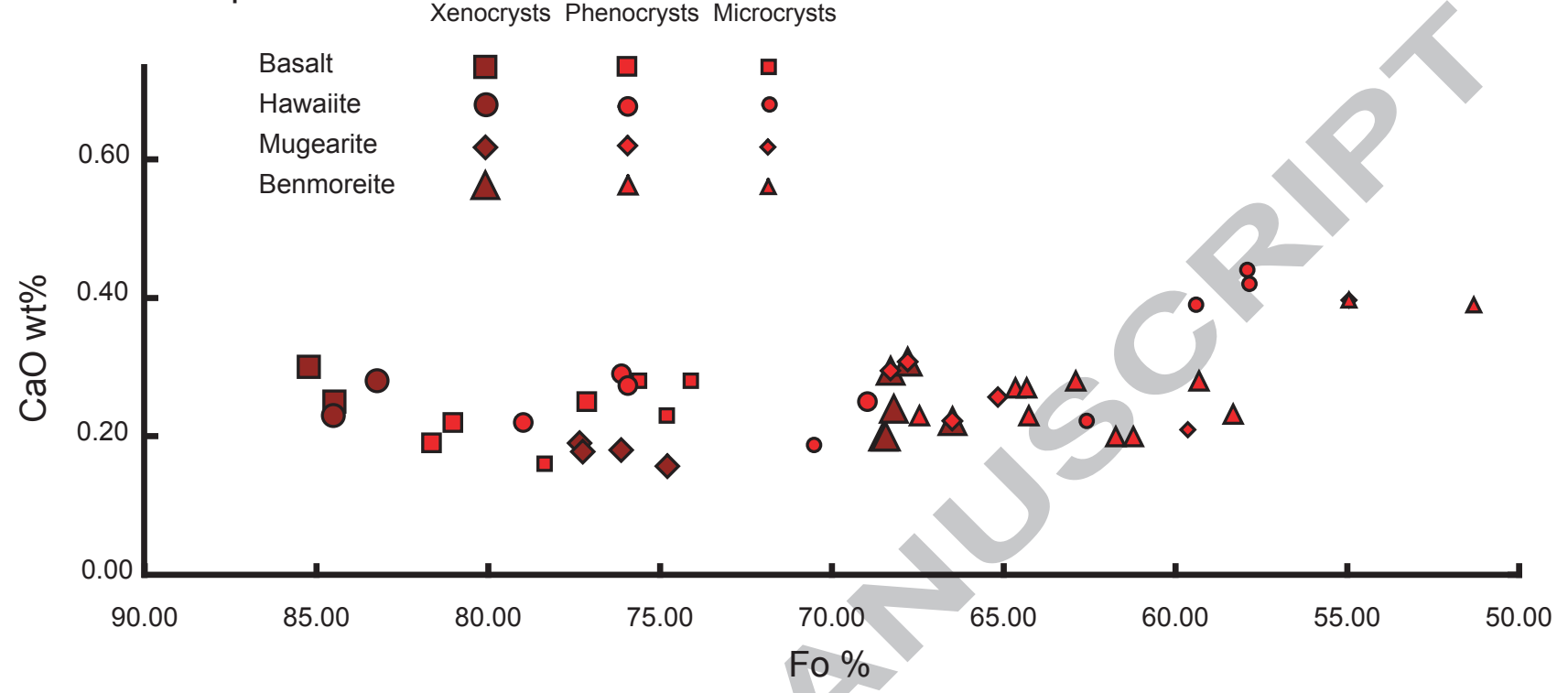

B Group 2

Xenocrysts Phenocrysts Microcrysts

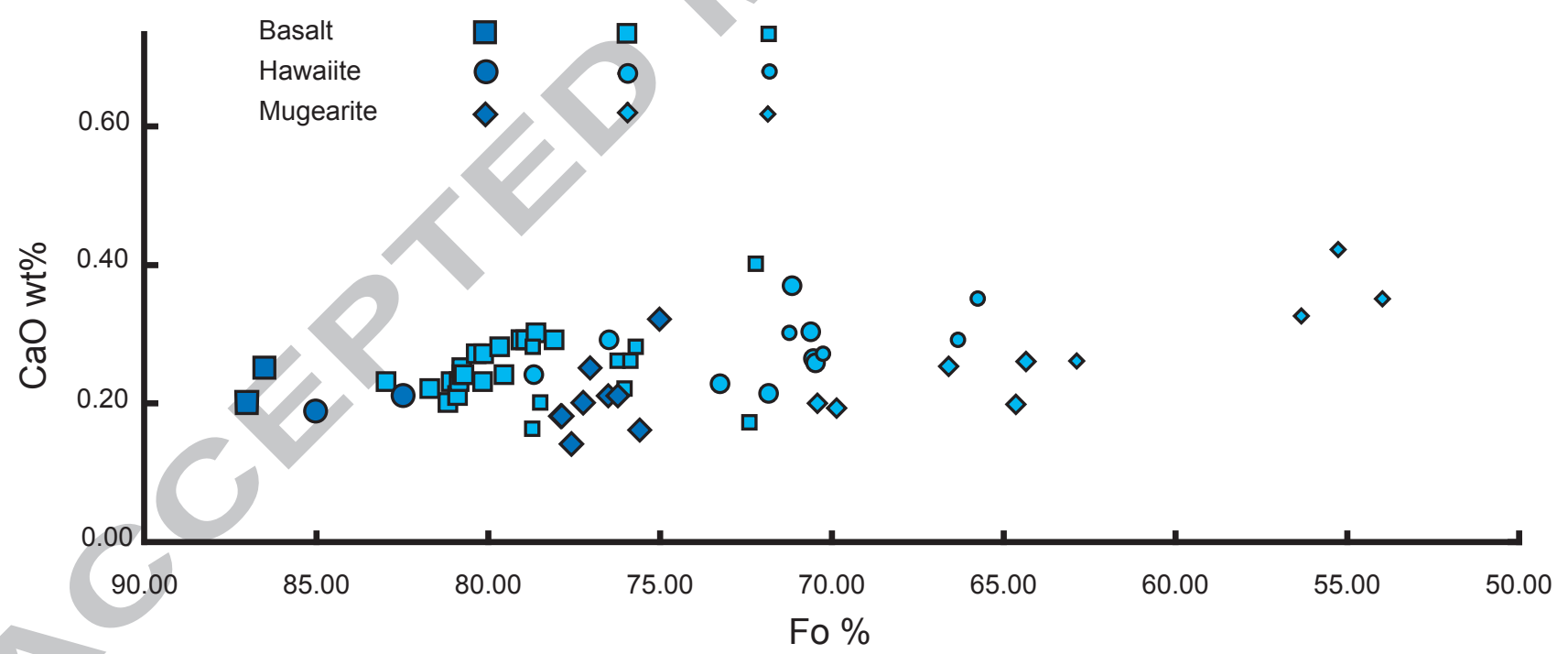




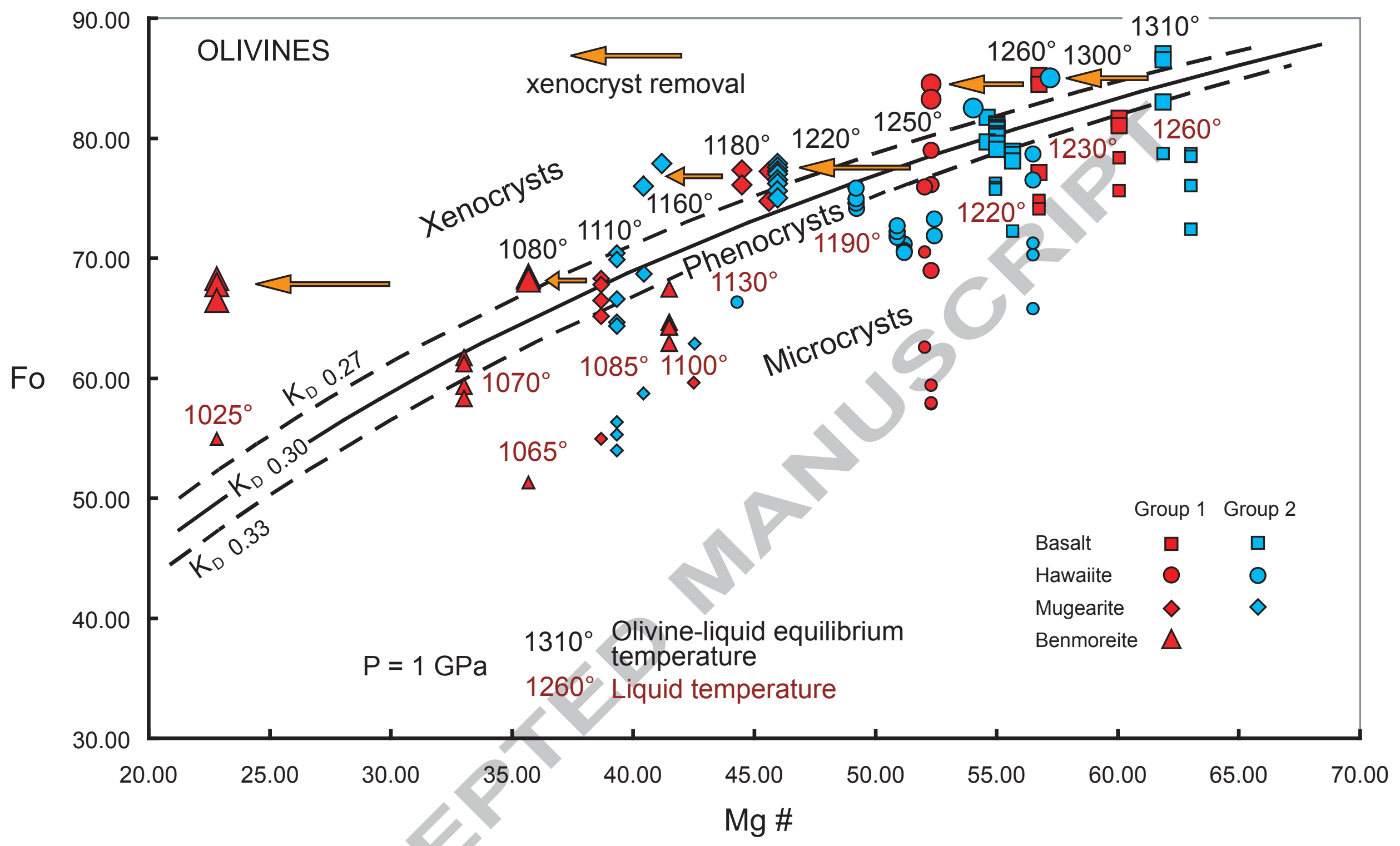


Fig. 10

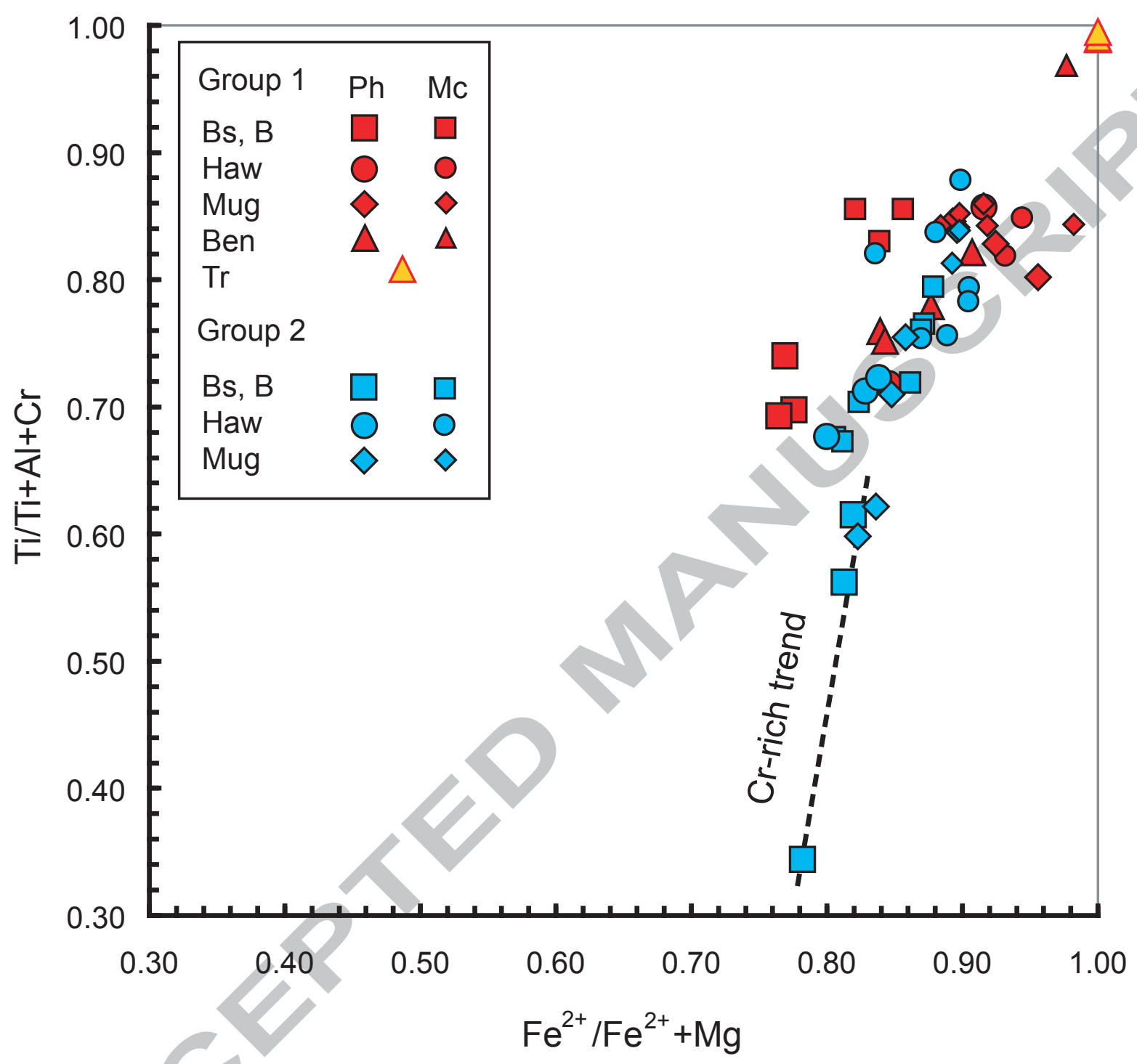




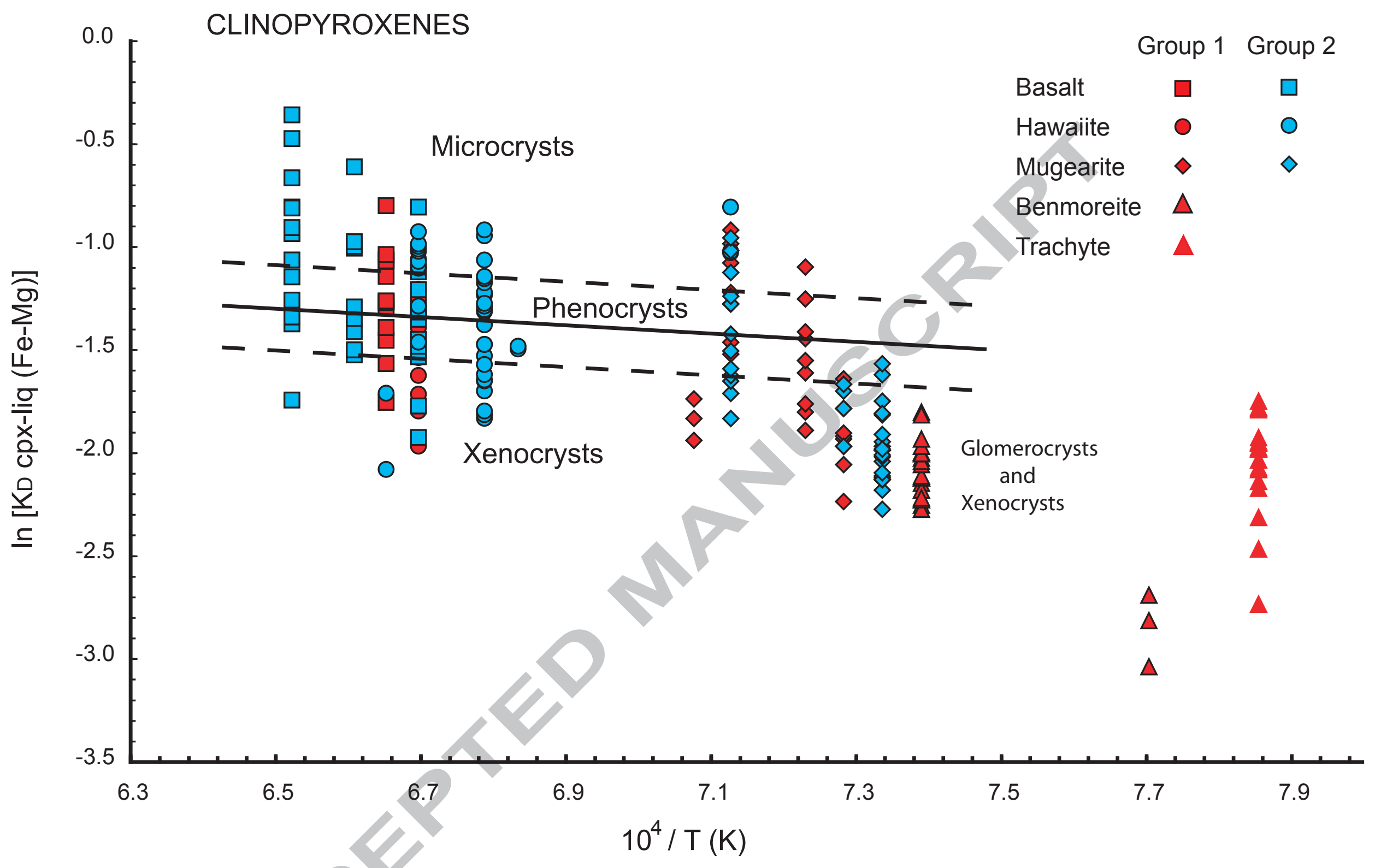


Fig. 12

\section{PYROXENES}

Xenocryst Phenocryst Microcryst
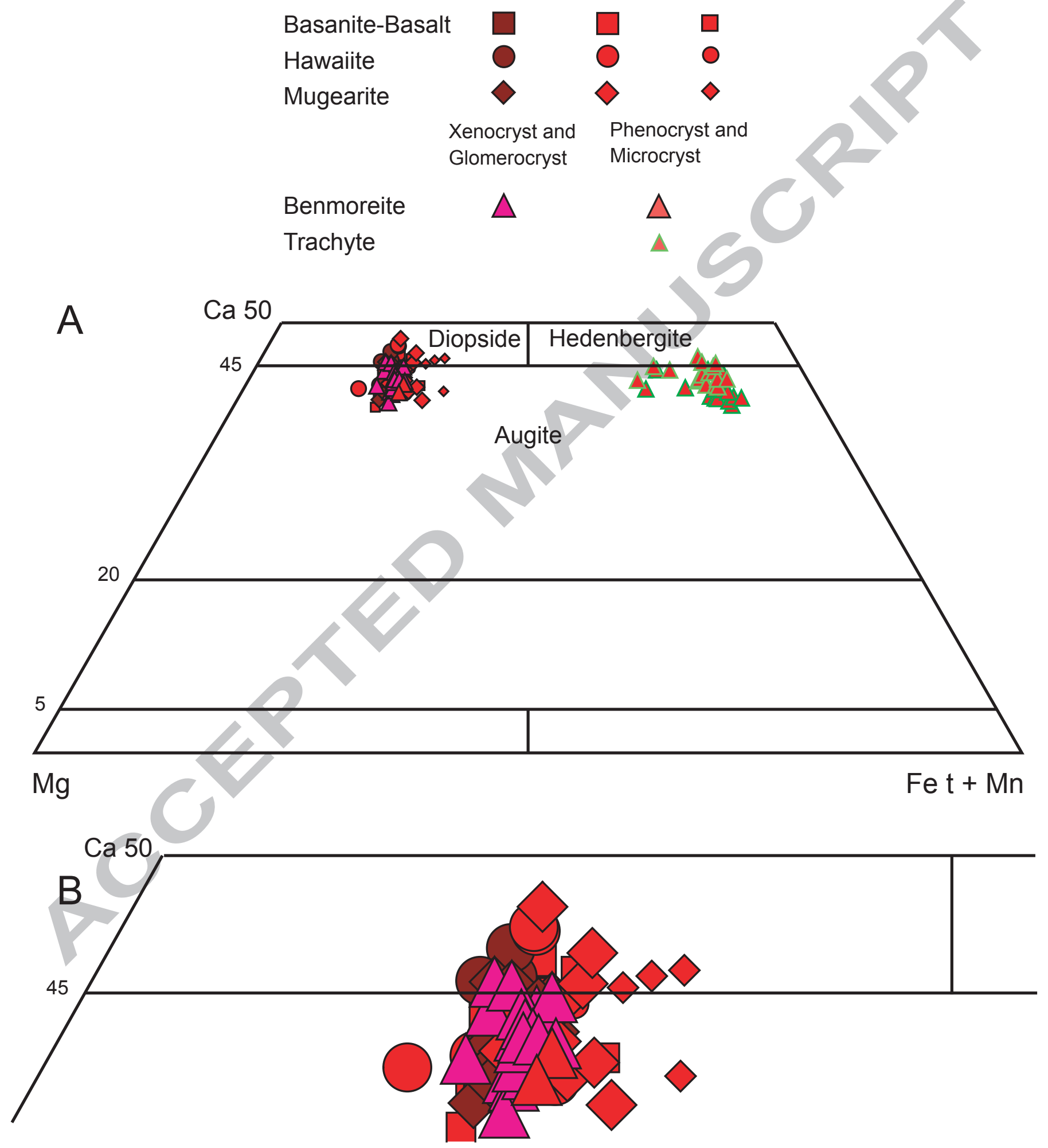
Fig. 13

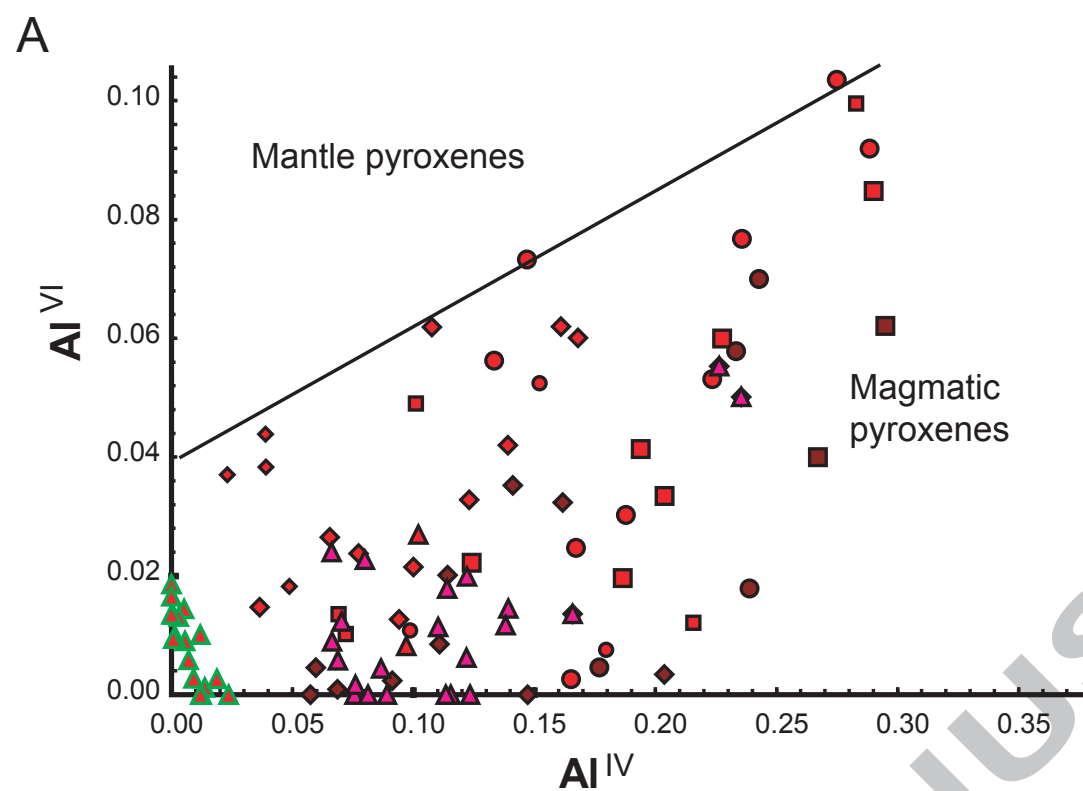

B

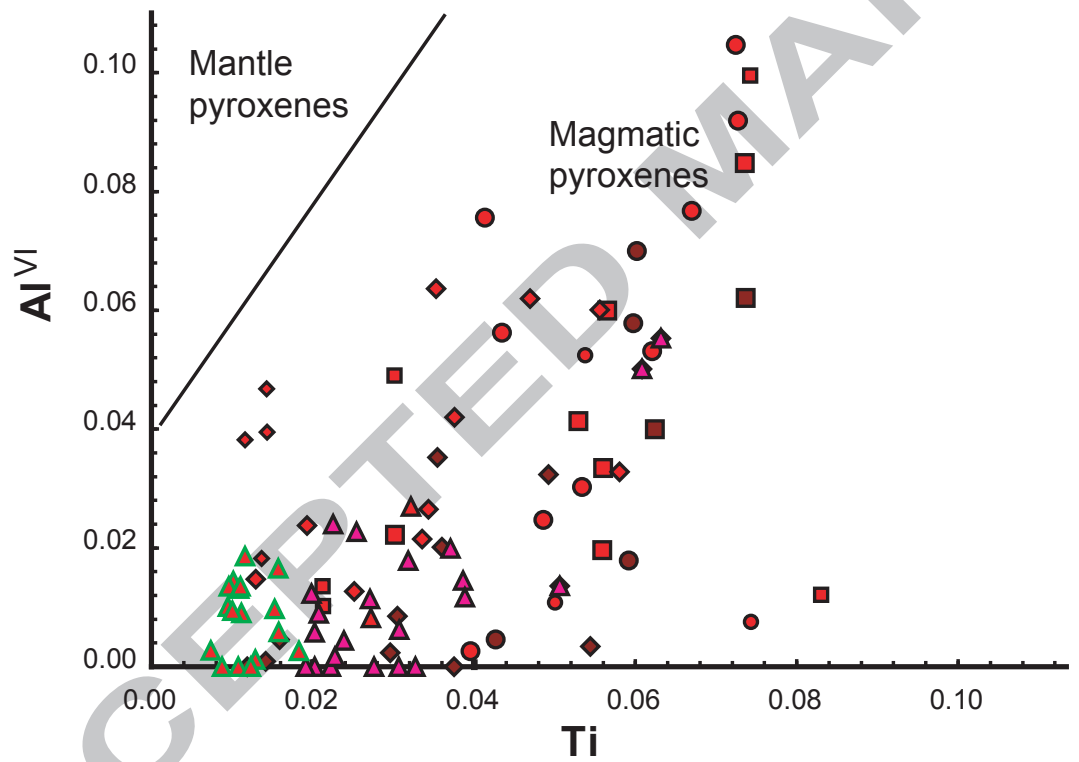

c

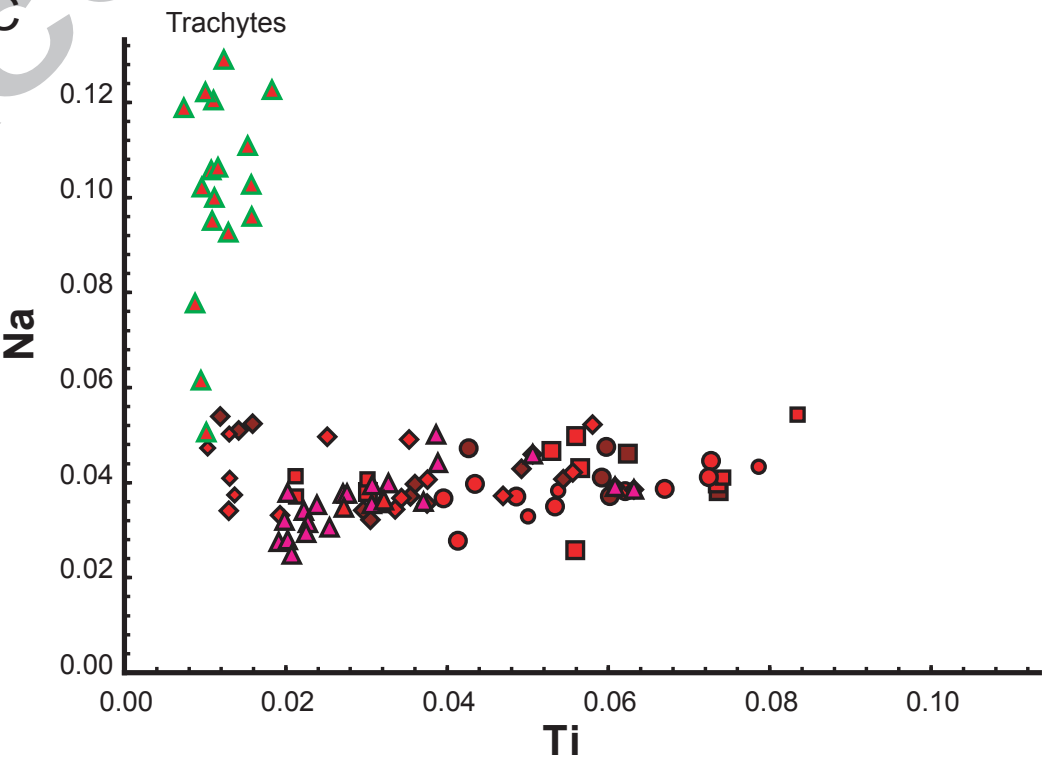


Fig. 14

\section{PYROXENES}

Xenocryst Phenocryst Microcryst

$\begin{array}{llll}\text { Basanite-Basalt } & \square & \square & \square \\ \text { Hawaiite } & \bigcirc & \bigcirc & 0 \\ \text { Mugearite } & \diamond & \diamond & \diamond\end{array}$

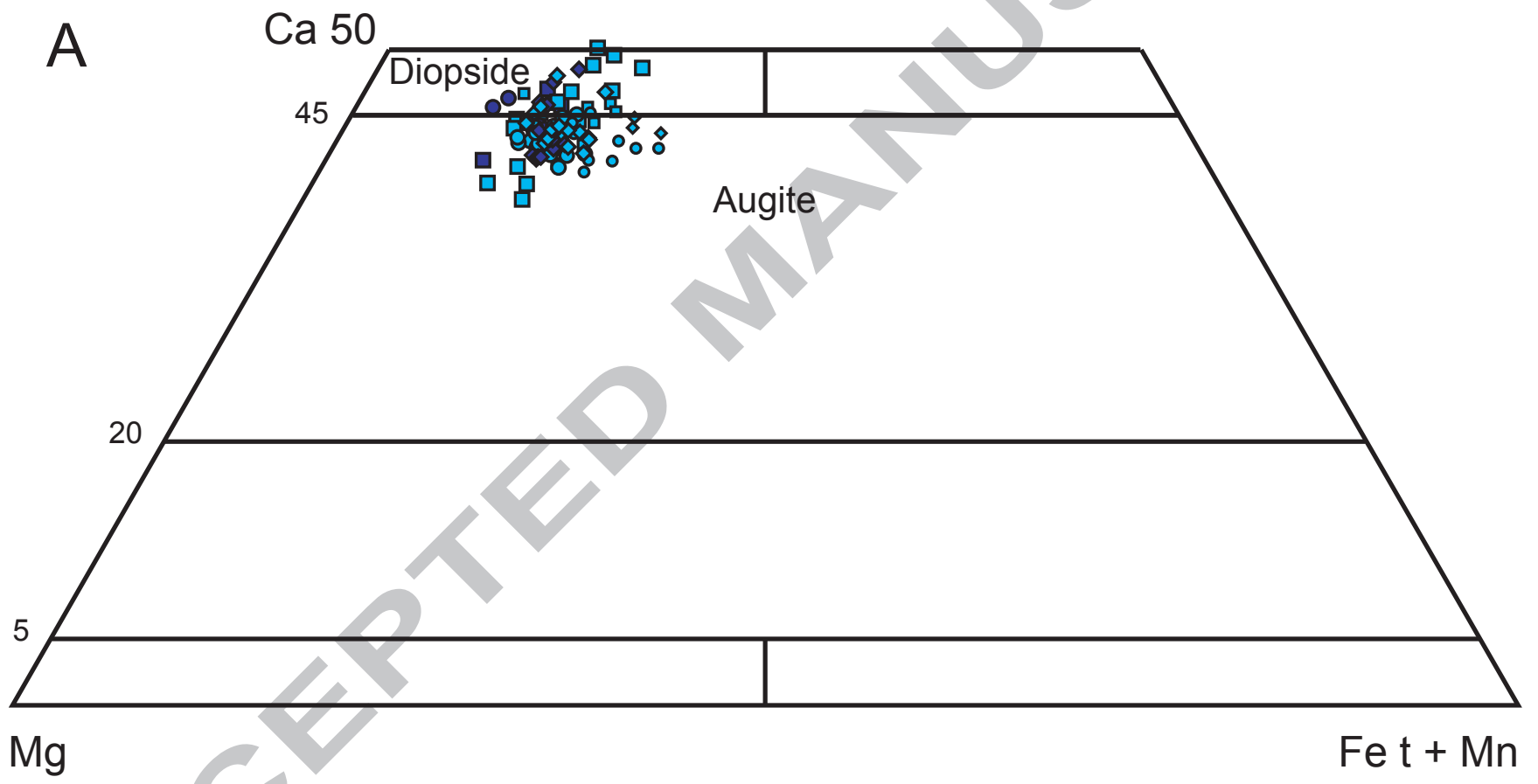

B

type b

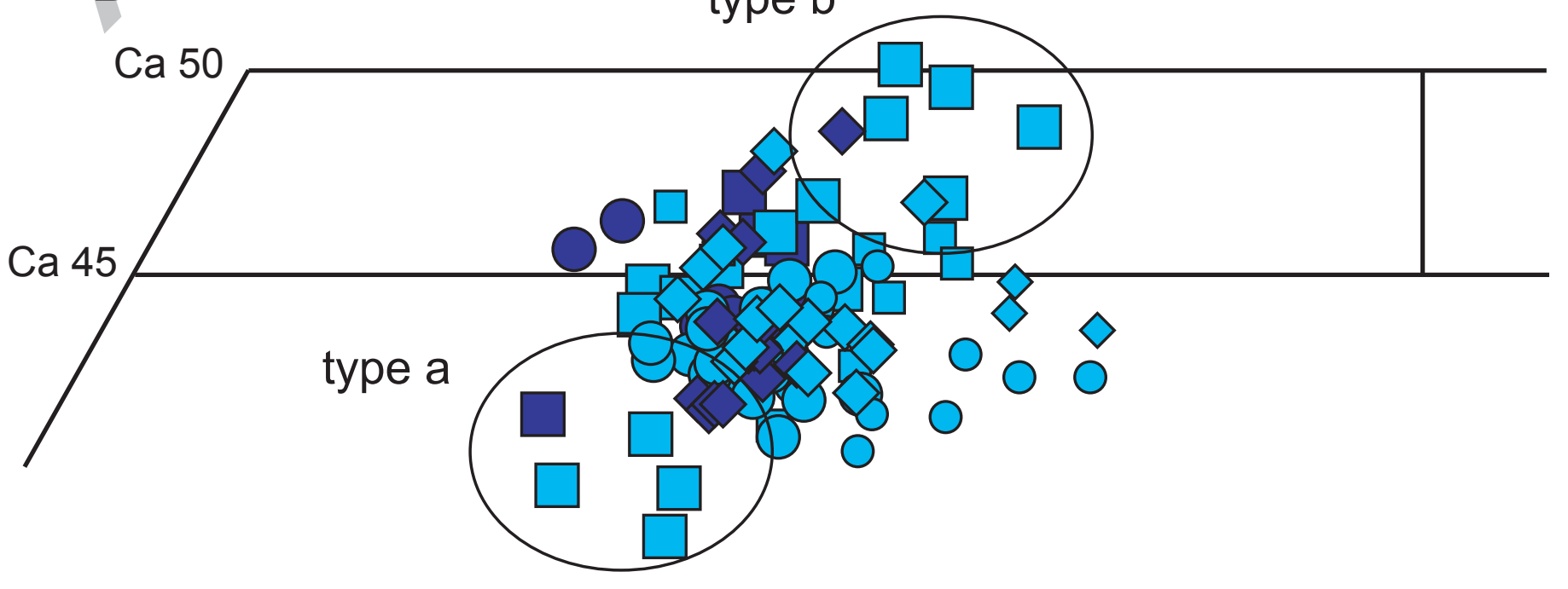


Fig. 15

A

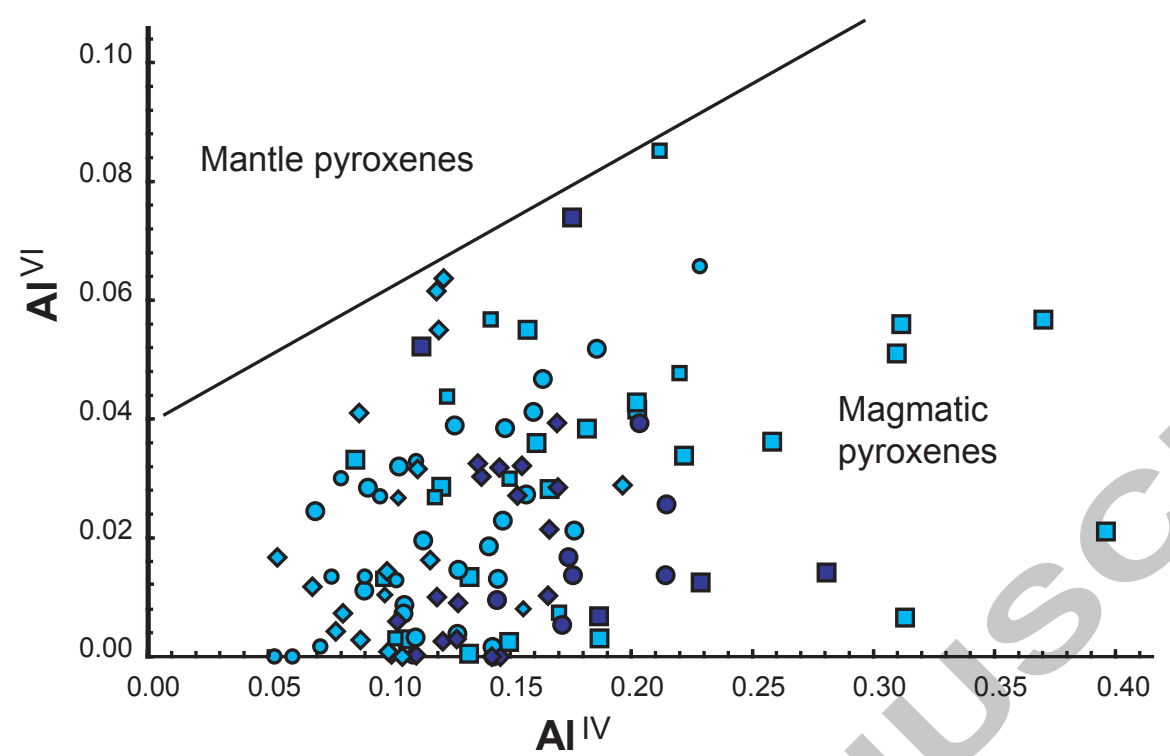

B

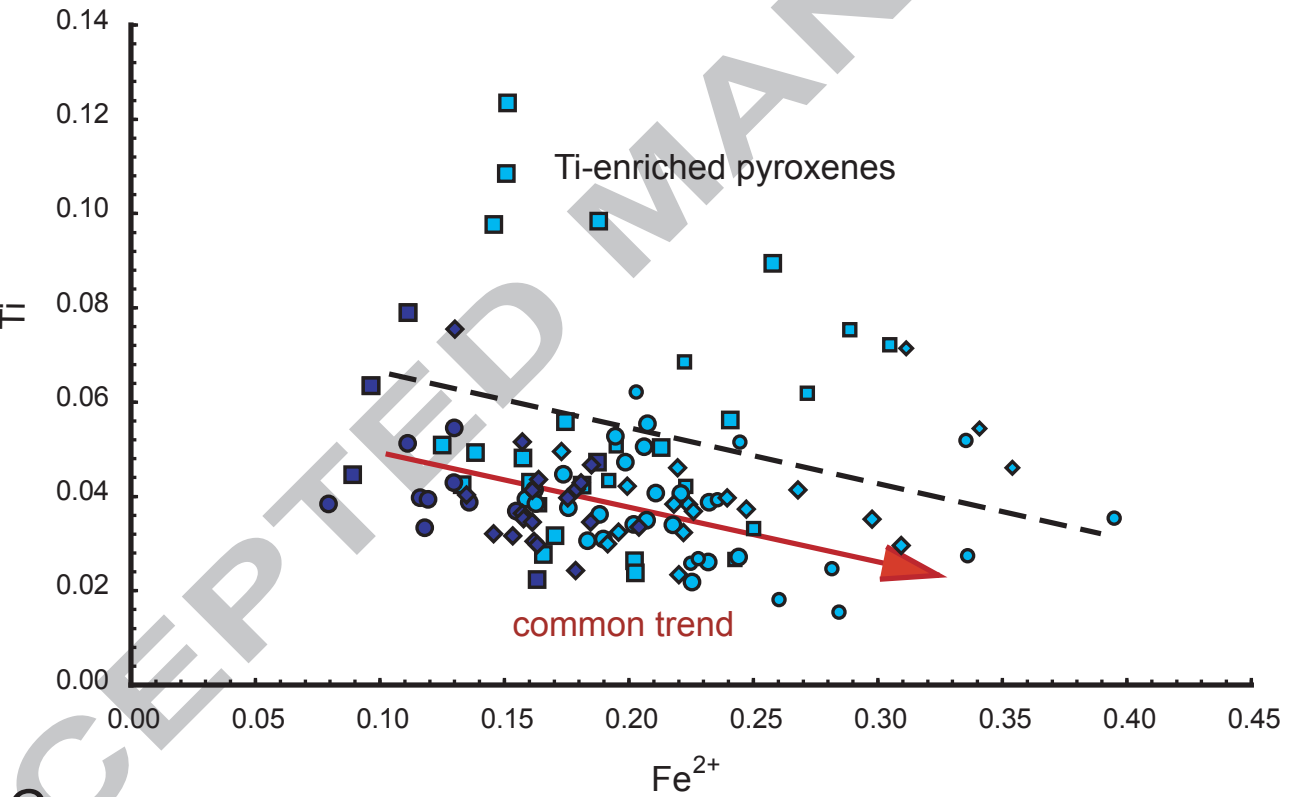

C

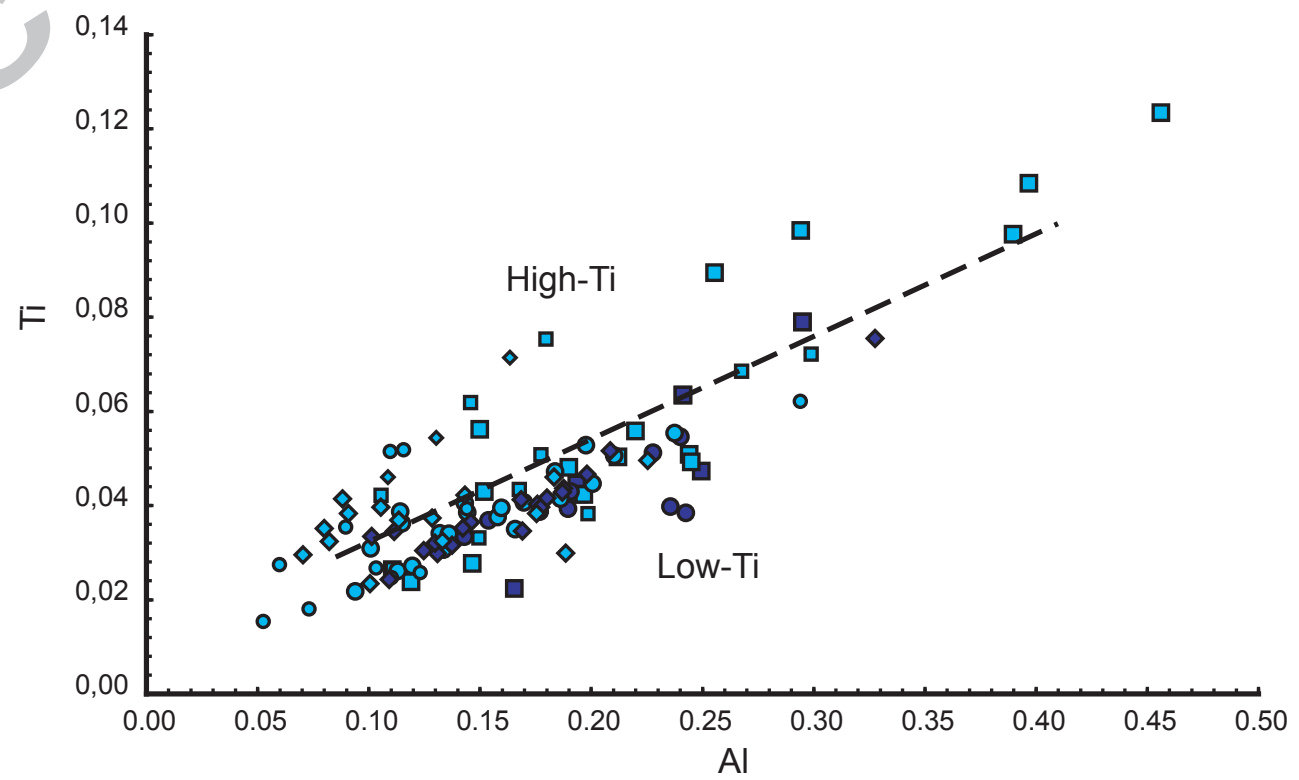



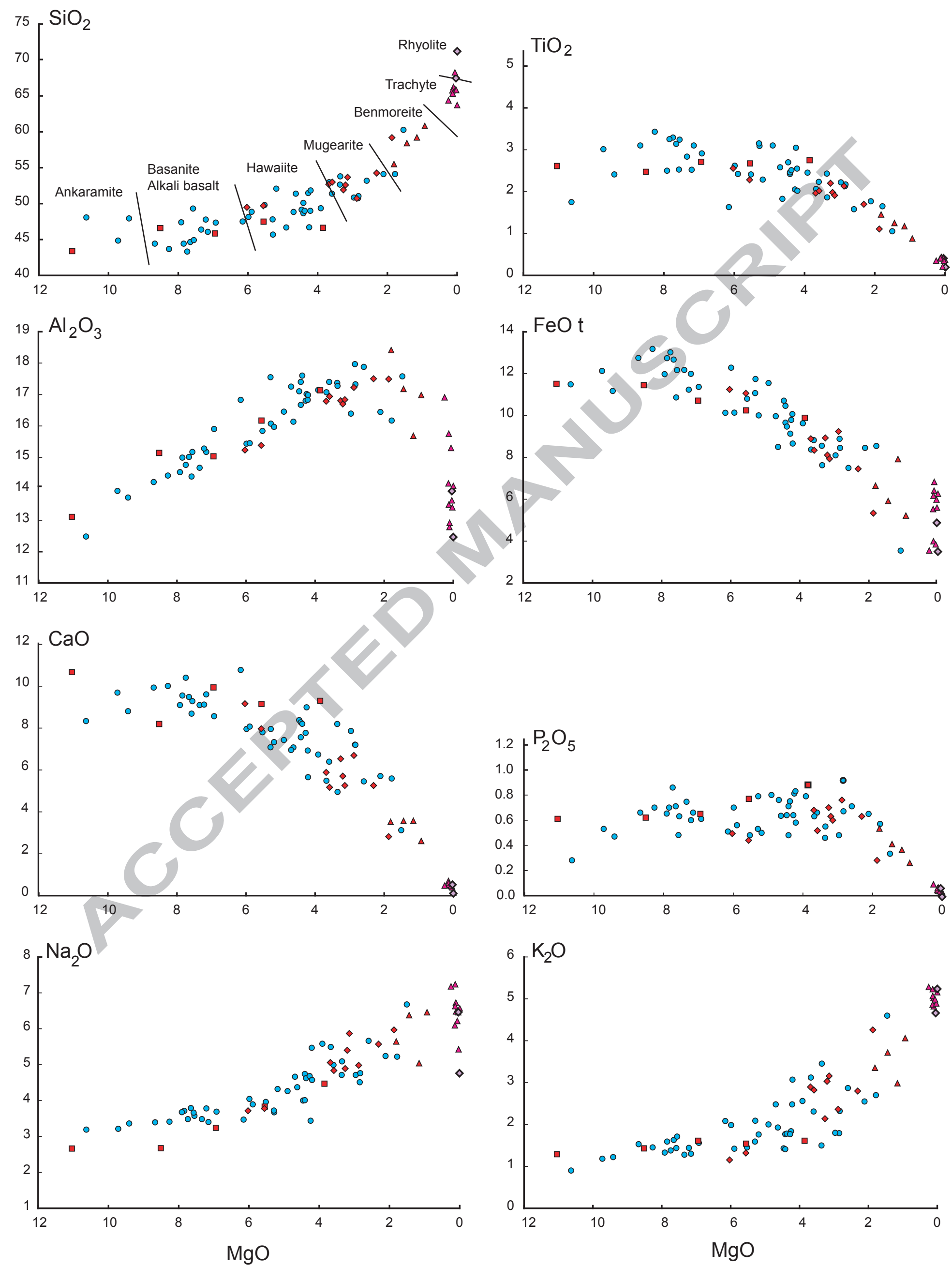
Fig. 17
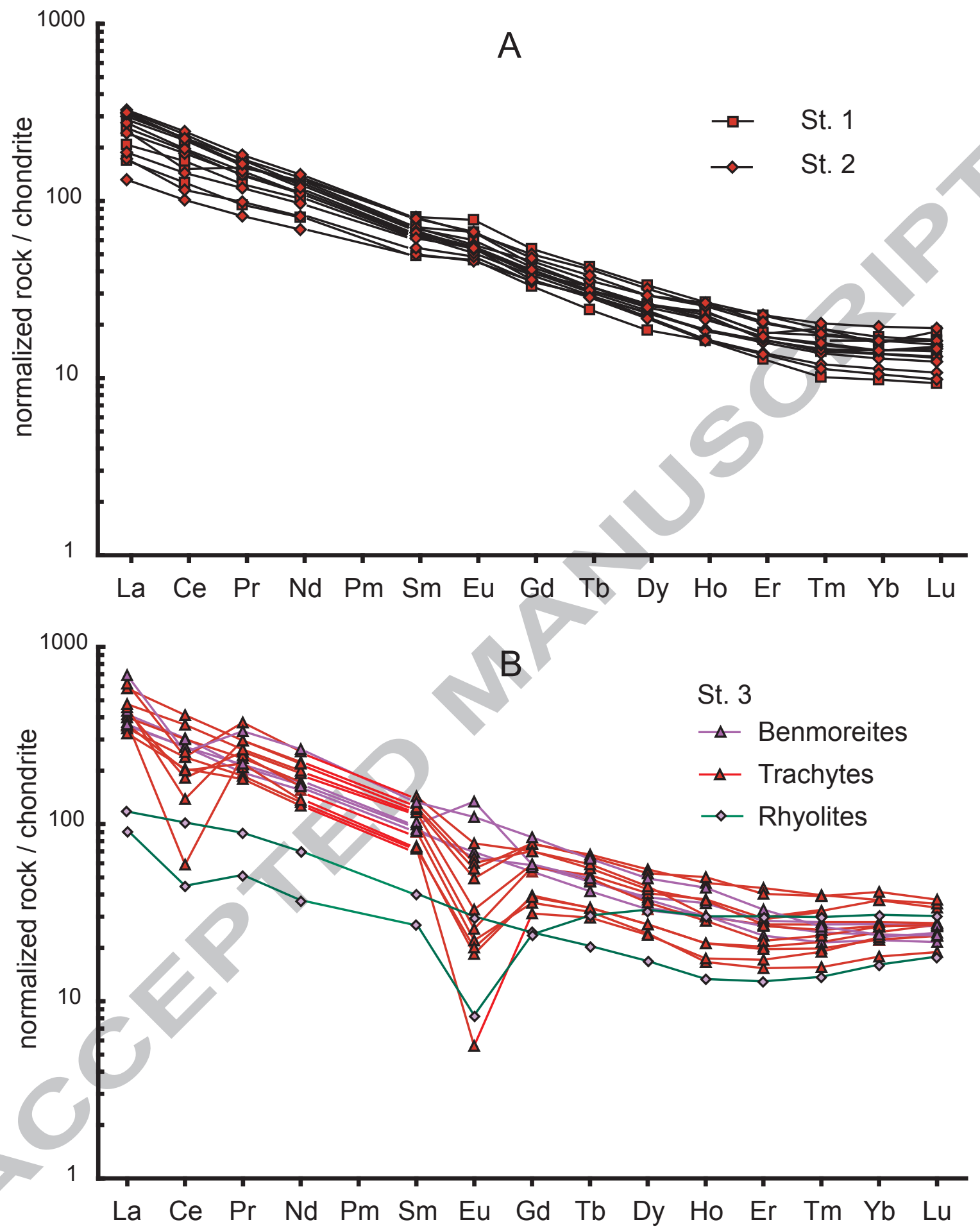
Fig. 17
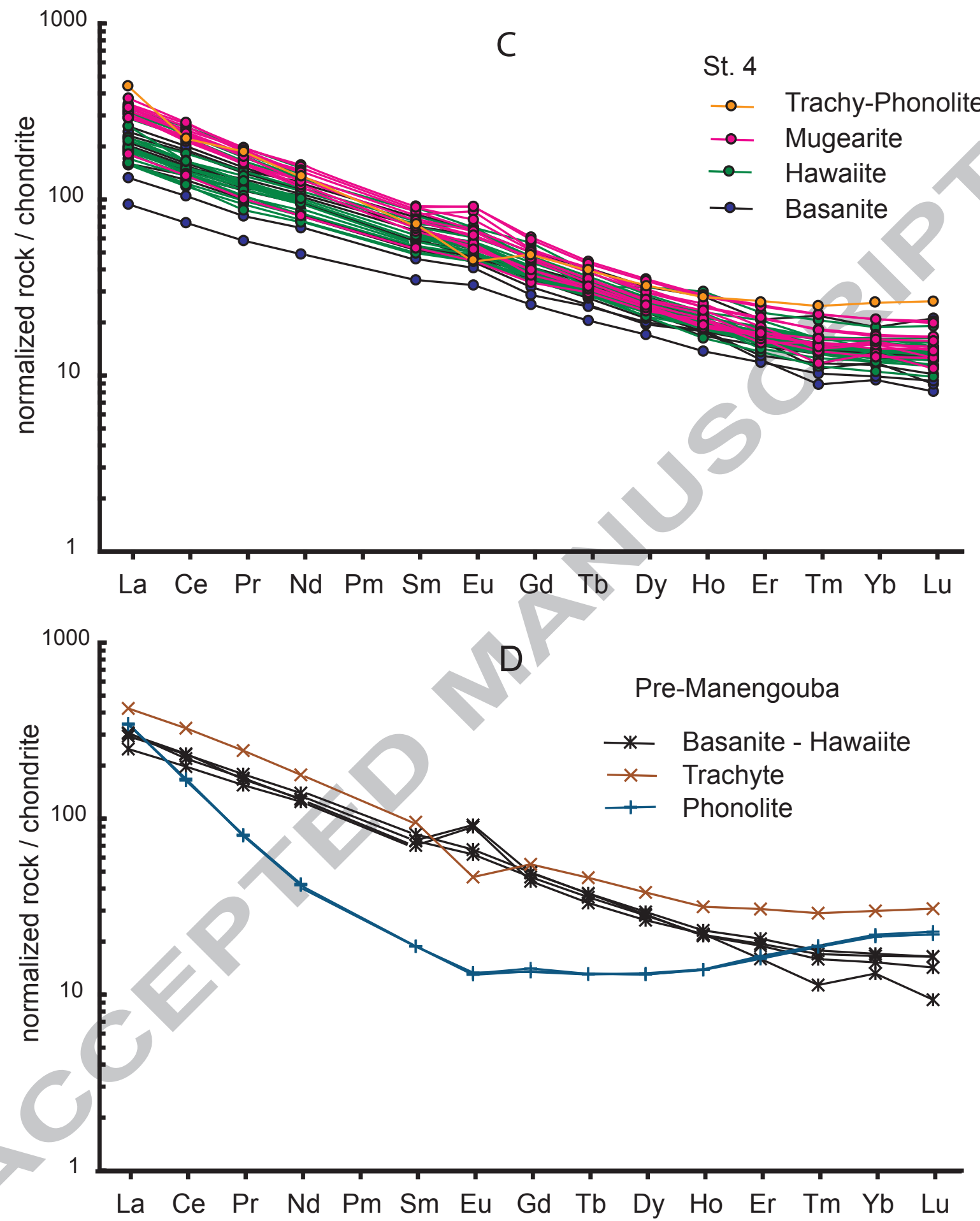
Fig. 18
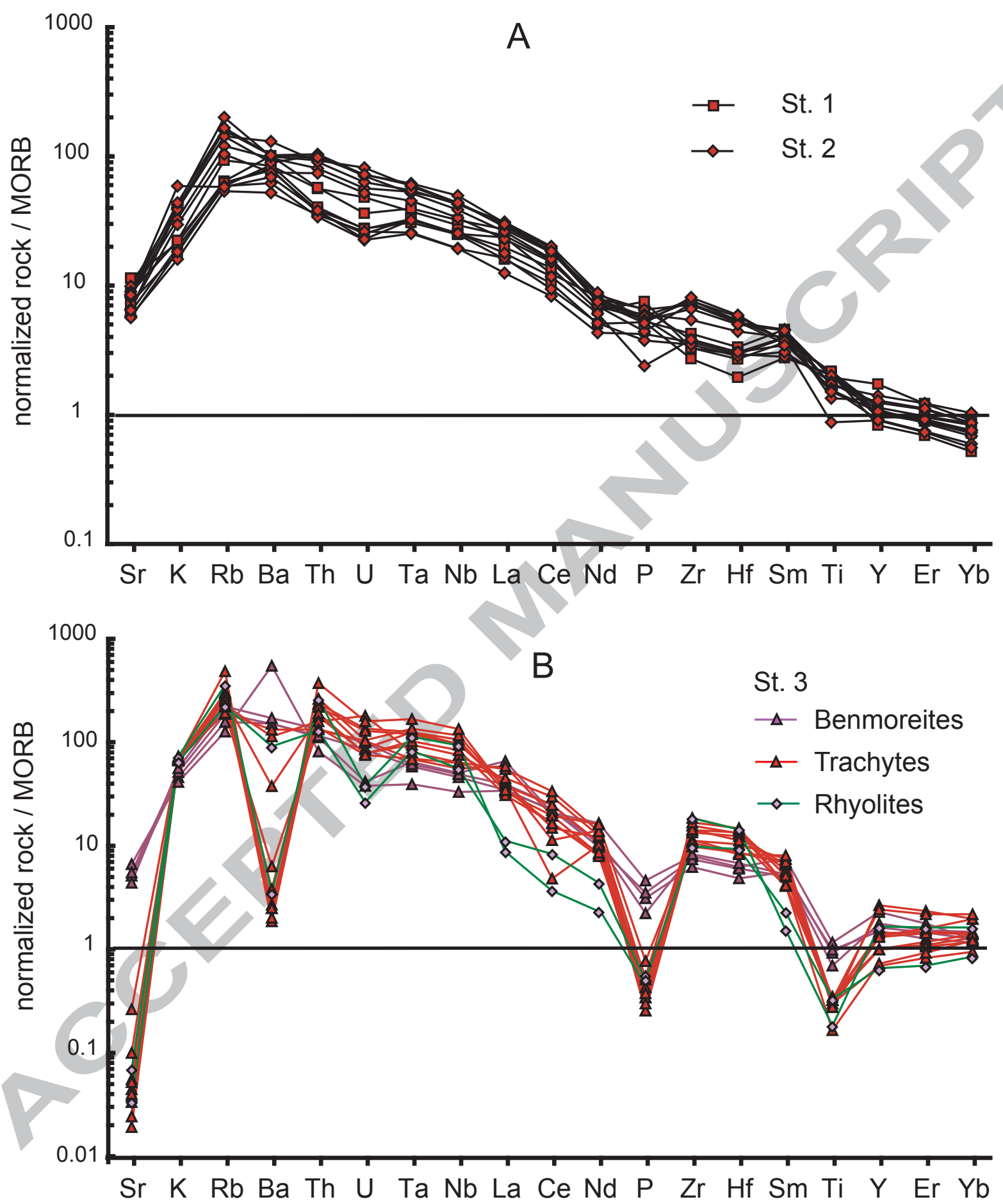
Fig. 18
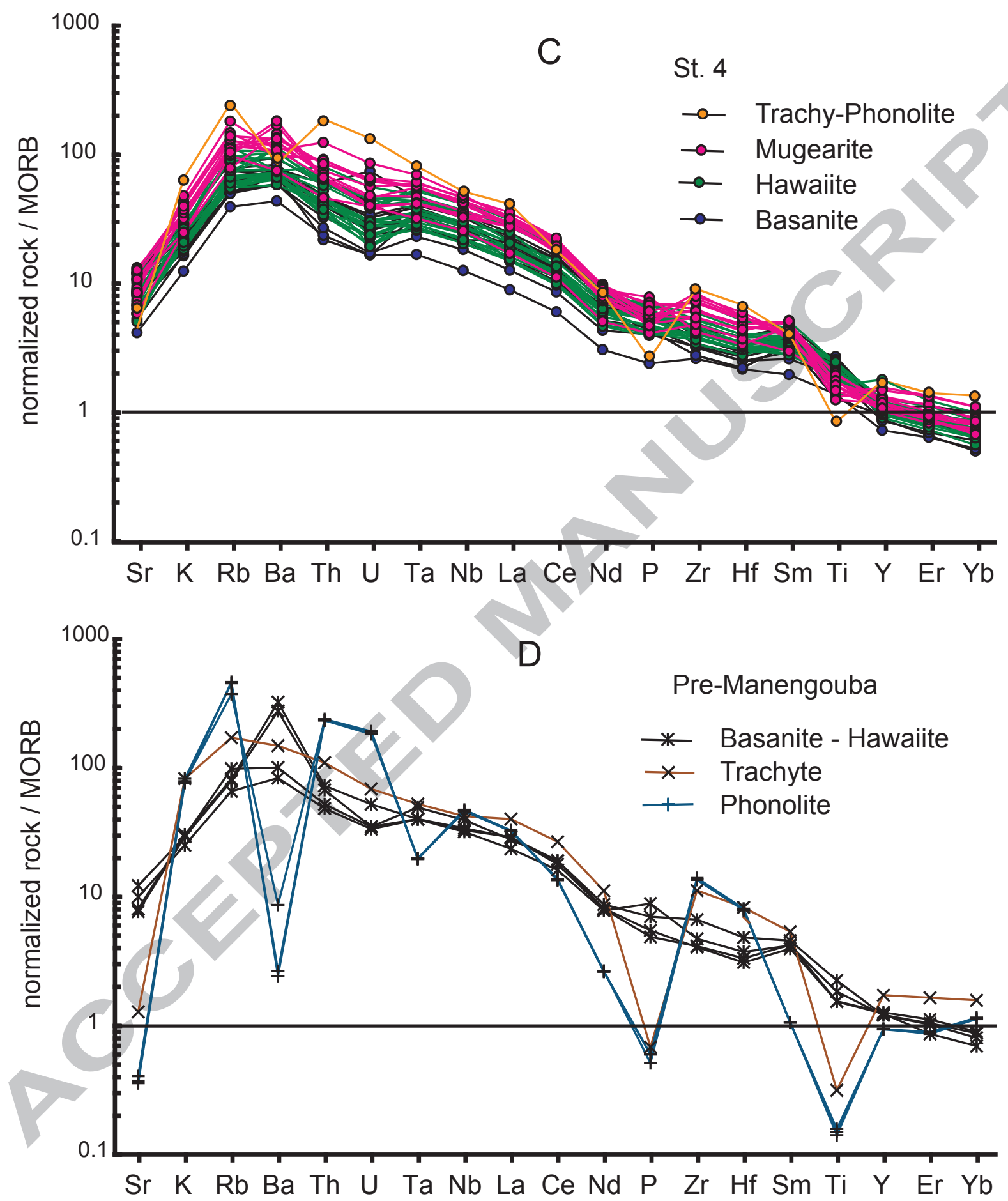
Fig. 19

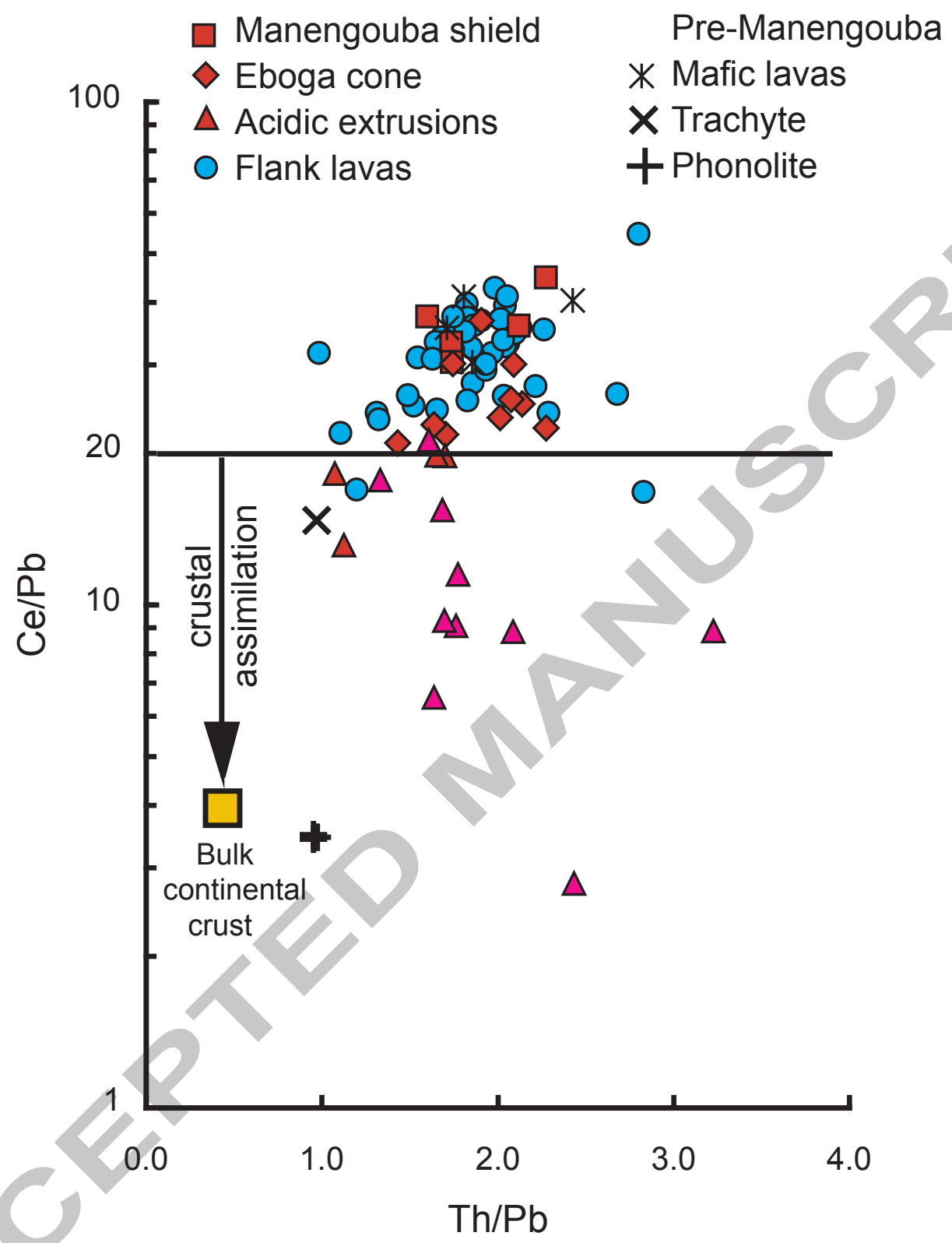


Fig. 20

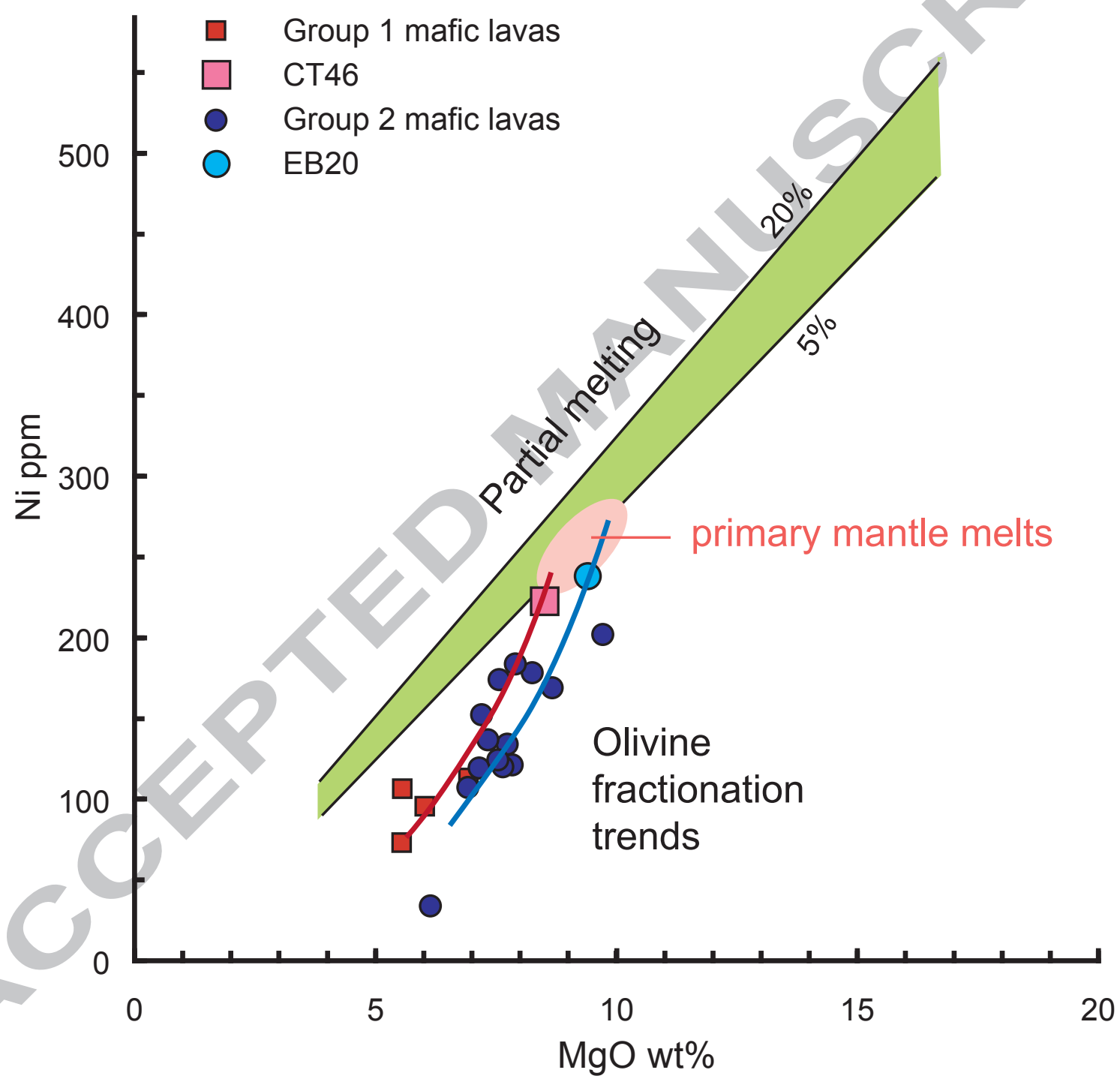


Fig. 21

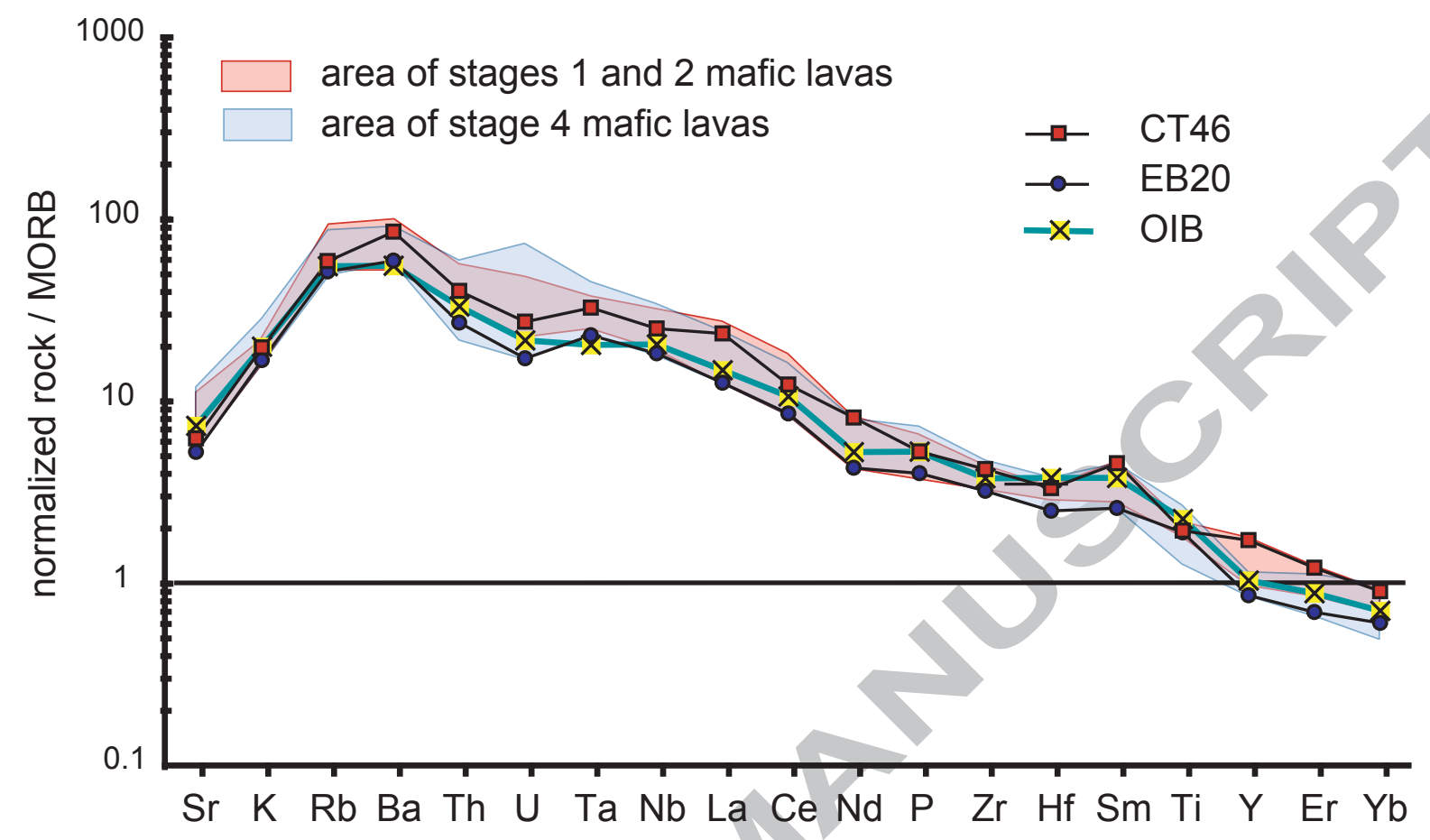


Fig. 22

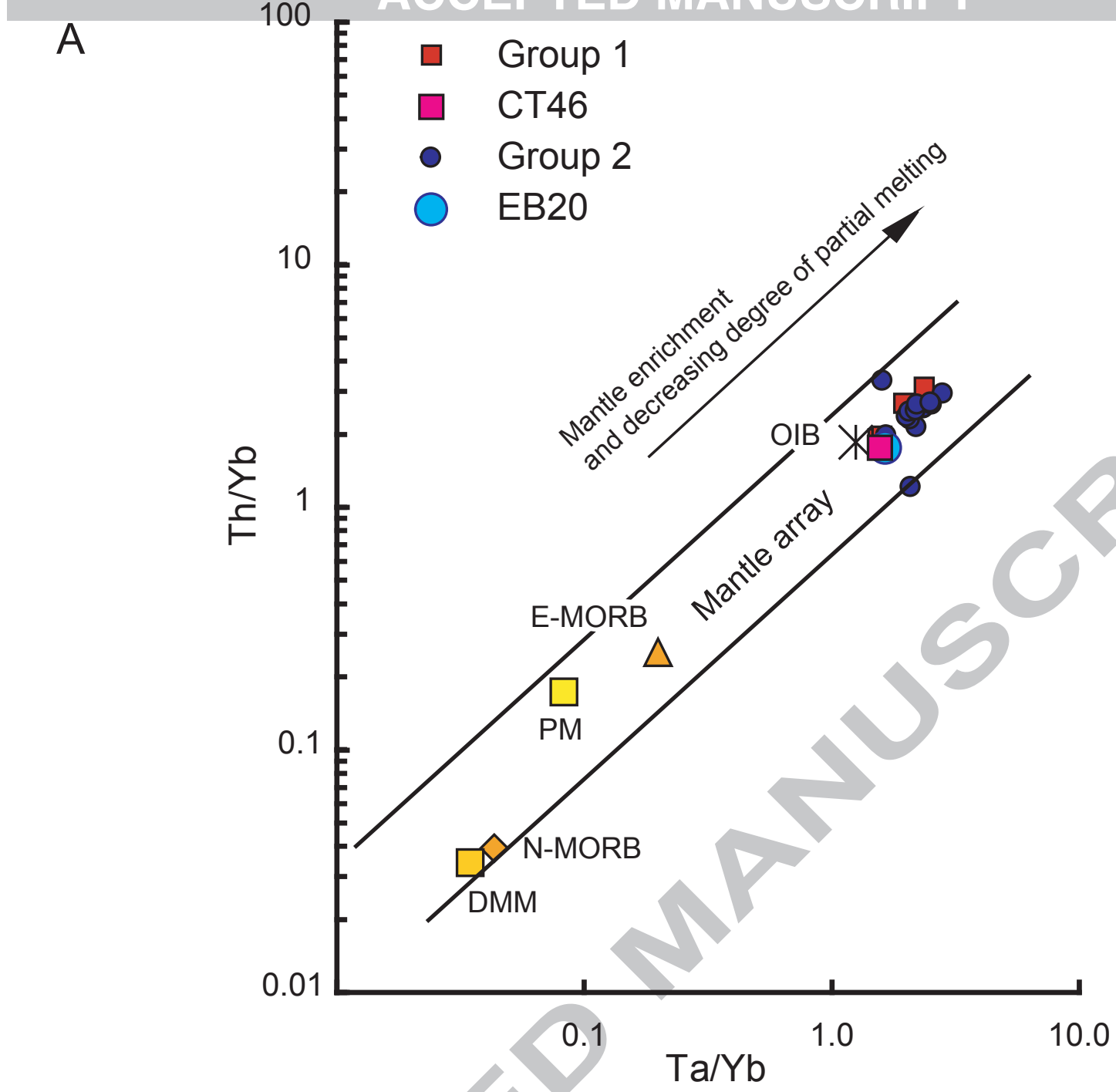

B

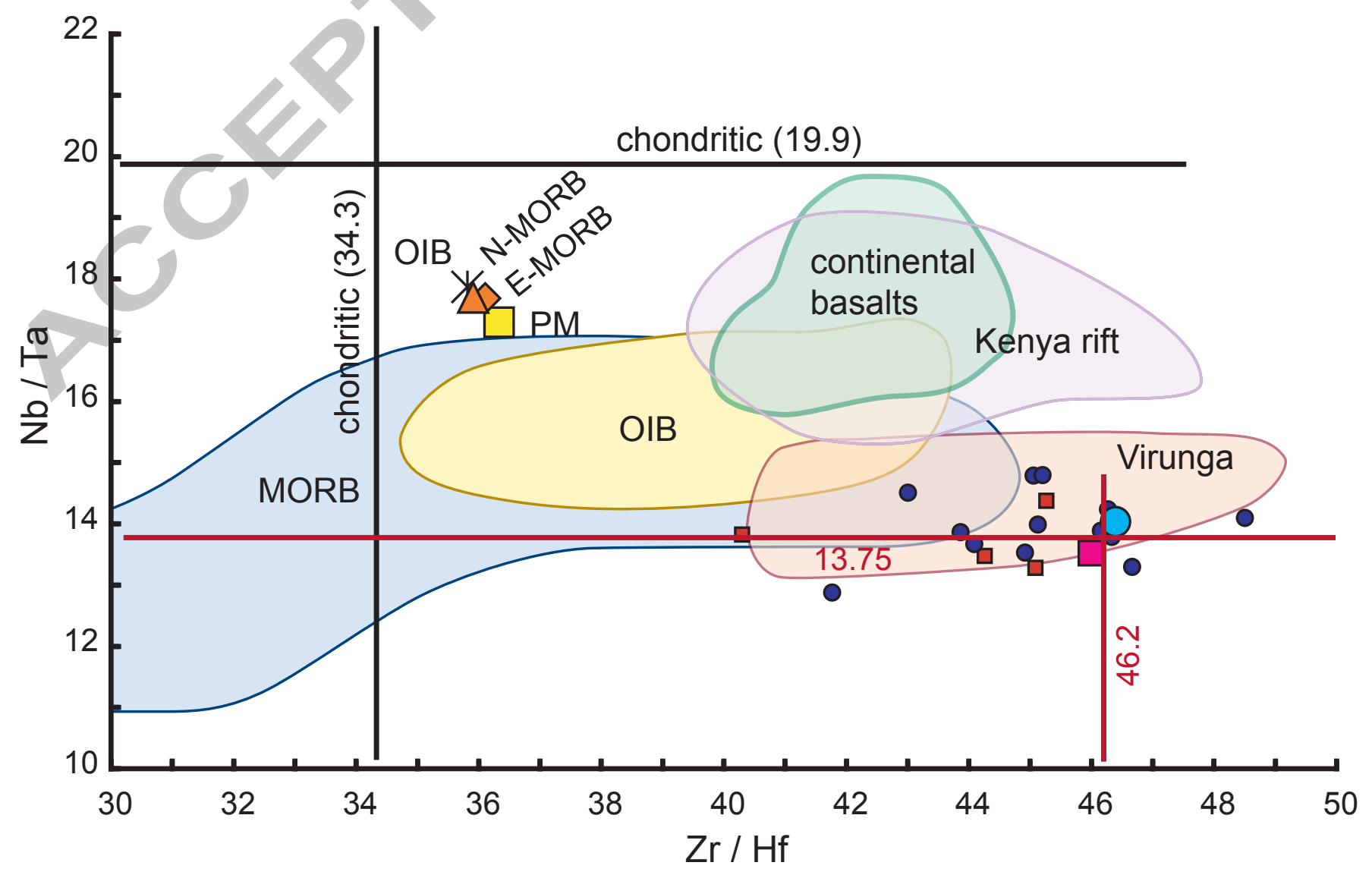


Fig. 23

A
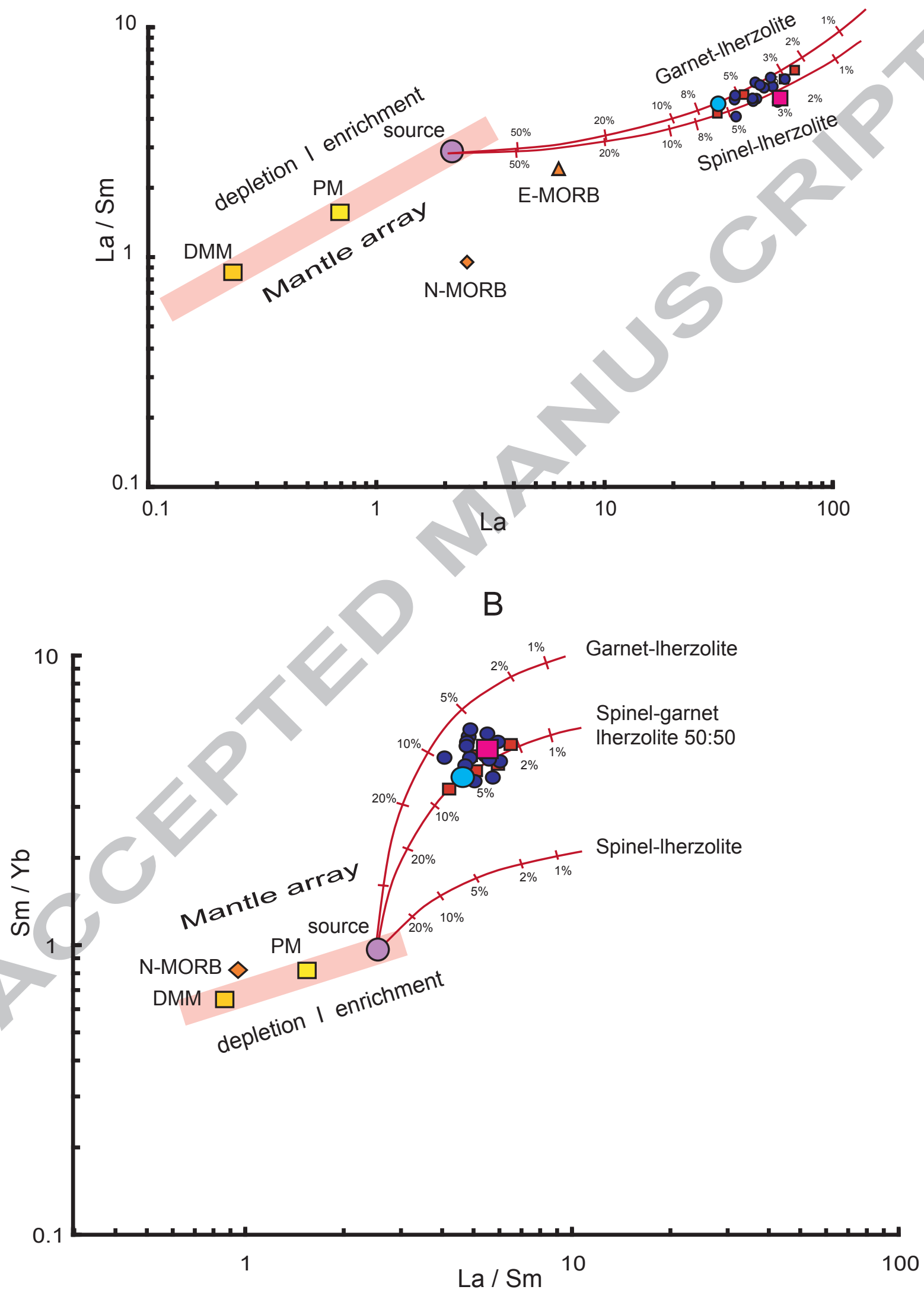
Fig. 24 ACCEPTED MANUSCRIPT
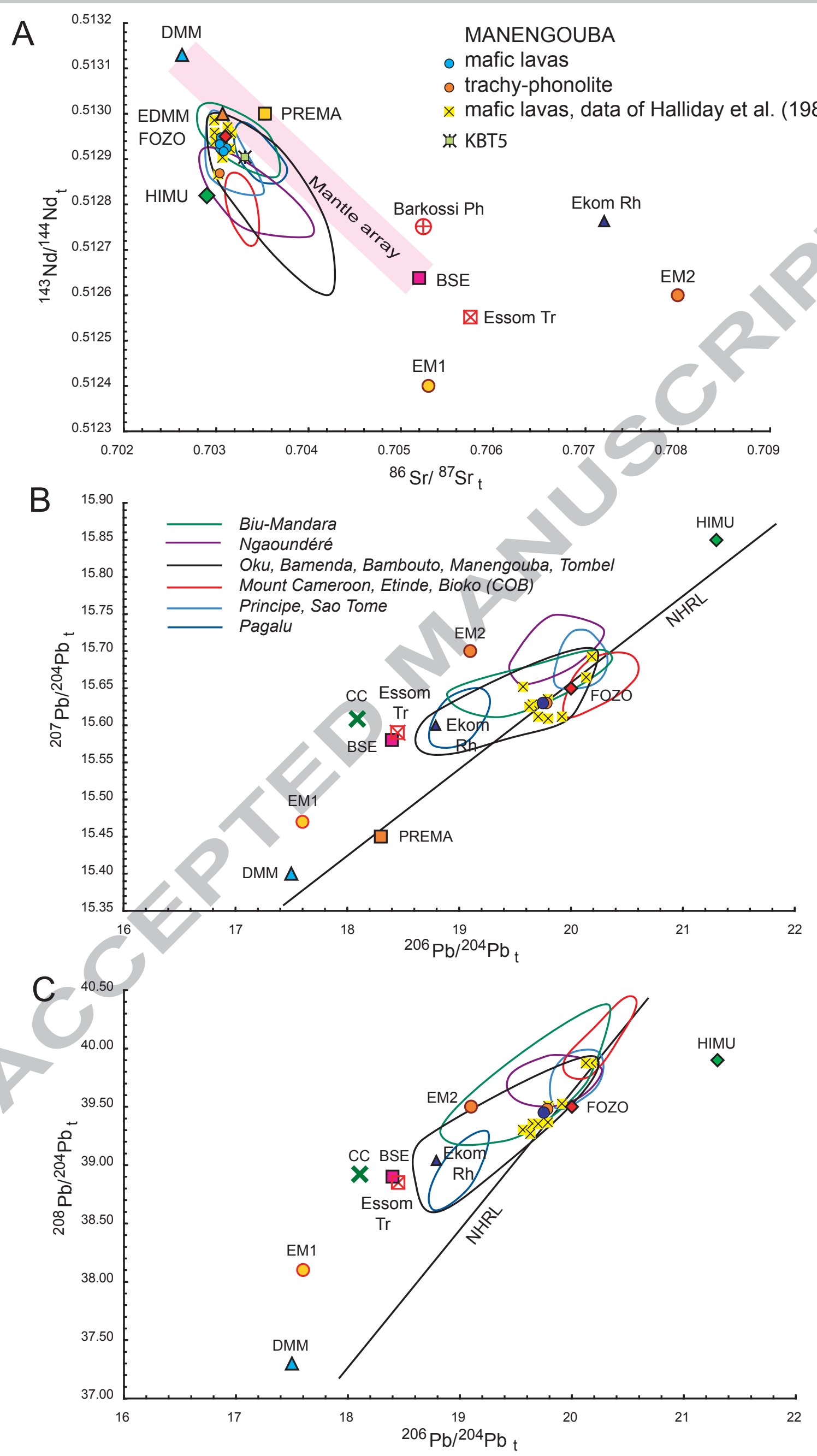
Fig. 24

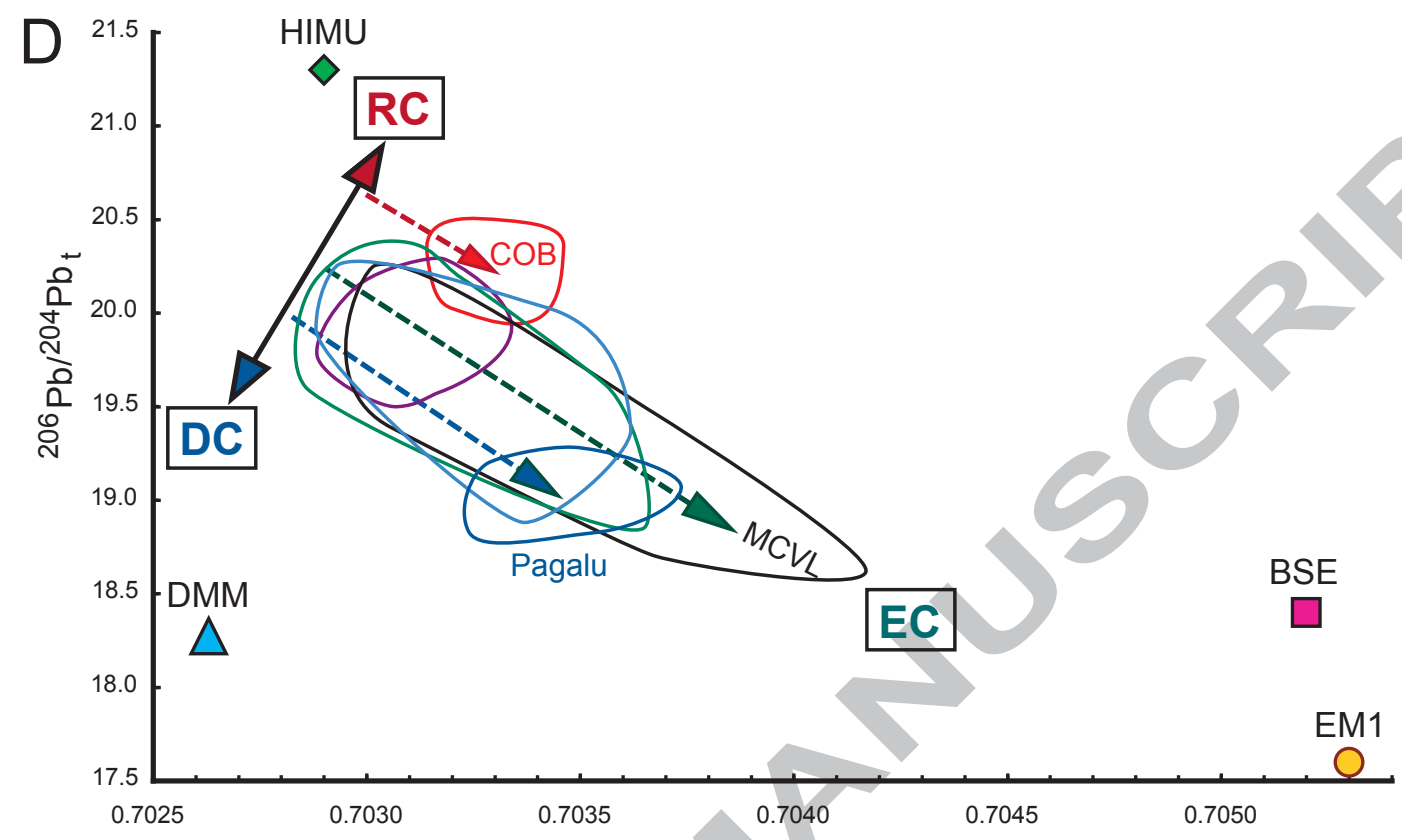


The Mount Manengouba, a complex volcano of the Cameroon Line: Volcanic history, petrological and geochemical features by André Pouclet et al.

1412

1413

1414

1415

1416

1417

1418

1419

1420

\section{Highlights}

The volcanic history of the Manengouba fit with four stages between 1.55 and $0.11 \mathrm{Ma}$. The volume of the volcano is calculated at $320 \mathrm{~km}^{3} \pm 5 \%$.

The magma was generated with 3 to $6 \%$ of partial melting of a fairly enriched source.

Melting of the source occurred in the lithospheric spinel to garnet transition zone.

Three source components are distinguished: depleted, radiogenic, and enriched. 


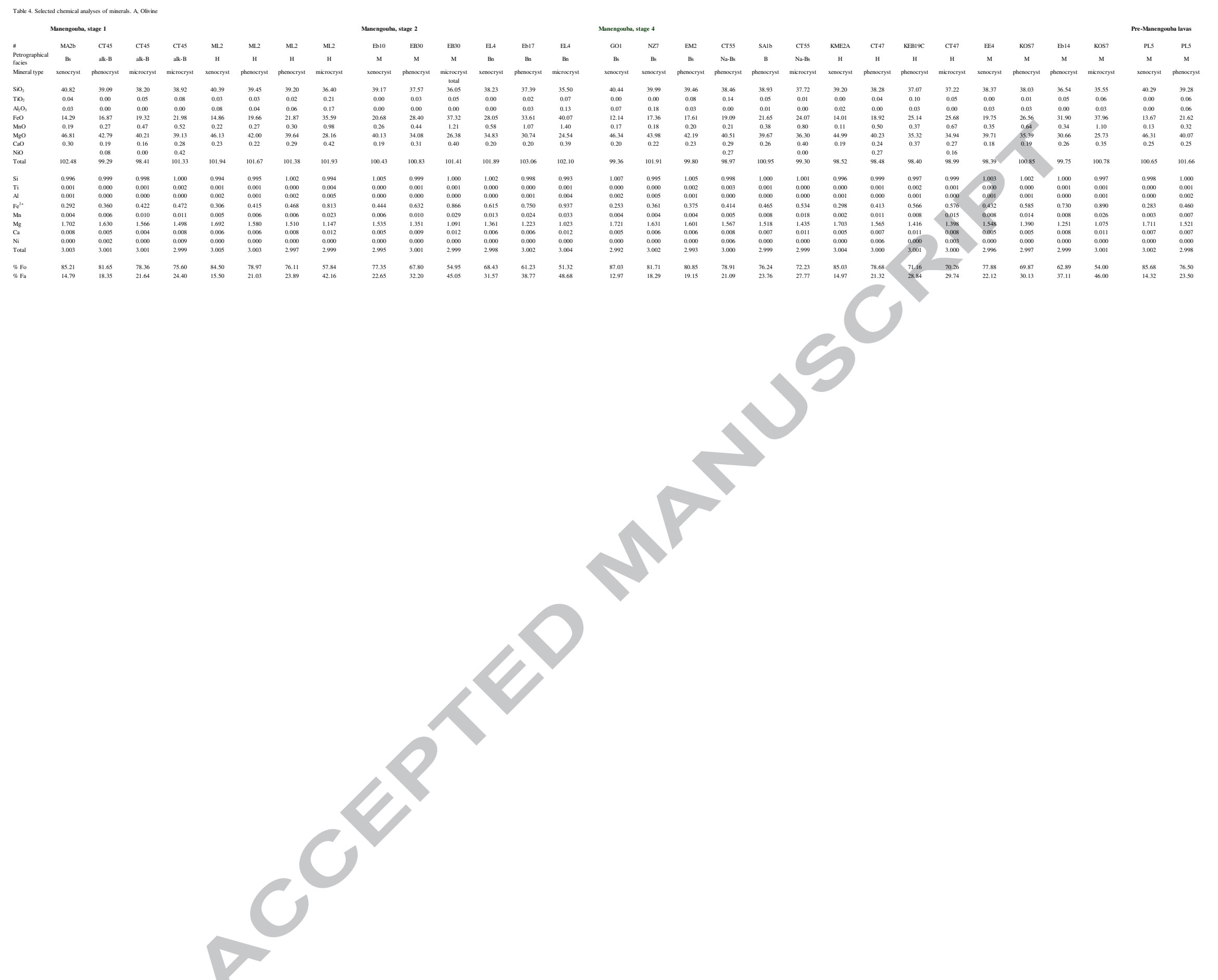


Table 4. Selected analyses of minerals. B, Magnetite Manengouba, stage 1

\begin{tabular}{|c|c|c|c|c|}
\hline & MA2b & MA2b & ML2 & ML2 \\
\hline $\begin{array}{l}\text { Petrographical } \\
\text { facies }\end{array}$ & Bs & Bs & H & $\mathrm{H}$ \\
\hline Mineral type & phenocryst & microcryst & phenocryst & microcryst \\
\hline $\mathrm{SiO}_{2}$ & 0.01 & 0.00 & 0.05 & 0.03 \\
\hline $\mathrm{TiO}_{2}$ & 17.51 & 18.59 & 20.85 & 19.25 \\
\hline $\mathrm{Al}_{2} \mathrm{O}_{3}$ & 4.83 & 4.15 & 5.17 & 2.30 \\
\hline $\mathrm{Cr}_{2} \mathrm{O}_{3}$ & 0.03 & 0.03 & 0.08 & 0.06 \\
\hline $\mathrm{FeO}$ & 69.24 & 68.05 & 67.73 & 73.12 \\
\hline $\mathrm{MnO}$ & 0.56 & 0.38 & 0.50 & 0.71 \\
\hline $\mathrm{MgO}$ & 6.25 & 6.55 & 4.54 & 1.78 \\
\hline Total & 98.43 & 97.75 & 98.92 & 97.25 \\
\hline 11 & 0.003 & 0.000 & 0.014 & 0.009 \\
\hline $\mathrm{Al}$ & 1.578 & 1.367 & 1.706 & 0.797 \\
\hline Ti & 3.650 & 3.906 & 4.390 & 4.254 \\
\hline $\mathrm{Fe}^{3+}$ & 7.111 & 6.814 & 5.468 & 6.664 \\
\hline $\mathrm{Fe}^{2+}$ & 8.939 & 9.088 & 10.391 & 11.306 \\
\hline $\mathrm{Mg}$ & 2.582 & 2.728 & 1.895 & 0.780 \\
\hline $\mathrm{Mn}$ & 0.131 & 0.090 & 0.119 & 0.177 \\
\hline $\mathrm{Cr}$ & 0.007 & 0.007 & 0.018 & 0.014 \\
\hline Total & & & & \\
\hline
\end{tabular}

\section{Manengouba, stage 2}

NS2 Eb11 Eb1

H M M

phenocryst phenocryst microcryst

$\begin{array}{ccc}0.02 & 0.05 & 0.04 \\ 17.23 & 16.21 & 17.11 \\ 1.83 & 2.47 & 2.02 \\ 0.02 & 0.12 & 0.01\end{array}$

$\begin{array}{lll}1.03 & 0.12 & 0.01 \\ 73.75 & 7734 & 75.59 \\ 0.06 & 0.67 & 0.05\end{array}$

$\begin{array}{lll}0.46 & 0.67 & 0.85 \\ 2.22 & 1.16 & 0.47\end{array}$

$\begin{array}{lll}2.22 & 1.16 & 0.47 \\ 95.51 & 98.02 & 96.09\end{array}$

$\begin{array}{lll}0.004 & 0.015 & 0.012 \\ 0.642 & 0.850 & 0.715\end{array}$

$\begin{array}{lll}0.642 & 0.850 & 0.715 \\ 3.862 & 3.558 & 3.863 \\ 7.62 & 7.977 & \end{array}$

$\begin{array}{lll}7.621 & 7.977 & 7.532\end{array}$

$\begin{array}{lll}10.766 & 10.902 & 11.449\end{array}$

$\begin{array}{lll}0.986 & 0.505 & 0.210 \\ 0.115 & 0.166 & 0.216\end{array}$

$\begin{array}{lll}0.004 & 0.028 & 0.002 \\ 24000 & 24000 & 24000\end{array}$

\section{Manengouba, stage 3}

Bn $\quad$ Bn $\quad$ Bb17 KEB26

phenocryst phenocryst microcryst microcryst

$\begin{array}{cccc}0.04 & 0.00 & 0.01 & 0.06 \\ 18.32 & 19.85 & 19.29 & 16.68 \\ 3.68 & 2.72 & 3.49 & 0.06 \\ 0.03 & 0.04 & 0.00 & 0.00 \\ 71.28 & 71.67 & 70.80 & 75.01 \\ 0.63 & 1.02 & 0.69 & 1.47 \\ 4.49 & 2.60 & 3.46 & 0.00 \\ 98.47 & 97.90 & 97.74 & 93.27 \\ & & & \\ 0.011 & 0.000 & 0.003 & 0.018 \\ 1.224 & 0.929 & 1.181 & 0.021 \\ 3.889 & 4.325 & 4.166 & 3.929 \\ 6.968 & 6.411 & 6.482 & 8.086 \\ 9.861 & 10.954 & 10.520 & 11.557 \\ 1.889 & 1.121 & 1.481 & 0.000 \\ 0.151 & 0.250 & 0.168 & 0.389 \\ 0.007 & 0.010 & 0.000 & 0.000 \\ 20000 & 24000 & 24000 & 24000\end{array}$

4 phenocryst phenocryst phenocryst microcryst phenocryst phenocryst phenocryst microcryst phenocryst microcryst

\begin{tabular}{|c|c|c|}
\hline 0.00 & 0.00 & 0.00 \\
\hline 17.08 & 13.33 & 17.87 \\
\hline 4.86 & 8.00 & 4.76 \\
\hline 5.43 & 12.26 & 3.54 \\
\hline 62.34 & 56.32 & 64.67 \\
\hline 0.66 & 0.49 & 0.58 \\
\hline $\begin{array}{c}5.01 \\
05.31\end{array}$ & 5.54 & $\begin{array}{l}4.95 \\
.6\end{array}$ \\
\hline 95.38 & 95.94 & 96.37 \\
\hline 0.000 & 0.000 & 0.000 \\
\hline 1.656 & 2.665 & 1.607 \\
\hline 3.713 & 2.833 & 3.849 \\
\hline 5.678 & 4.930 & 5.894 \\
\hline .393 & 8.382 & 9.595 \\
\hline 15 & 2.334 & 2.113 \\
\hline 1.162 & 0.117 & 0.141 \\
\hline 1.241 & & 0.802 \\
\hline
\end{tabular}
$\begin{array}{lllllllllll}2.159 & 2.334 & 2.113 & 2.173 & 1.491 & 1.396 & 2.009 & 2.277 & 1.354 & 1.323 \\ 0.162 & 0.117 & 0.141 & 0.080 & 0.101 & 0.220 & 0.111 & 0.135 & 0.244 & 0.205 \\ 1.241 & 2.740 & 0.802 & 0.032 & 0.018 & 0.044 & 0.015 & 0.000 & 0.000 & 0.004 \\ 24.000 & 24.000 & 24.000 & 24.000 & 24.000 & 24.000 & 24.000 & 24.000 & 24.000 & 24.000\end{array}$

\section{Pre-Manengouba}

KBT5 PL5

H M
phenocryst microcryst

$0.00 \quad 0.06$ $\begin{array}{lr}18.04 & 19.59 \\ 4.49 & 4.22\end{array}$ $\begin{array}{ll}4.49 & 4.22 \\ 0.20 & 1.06 \\ 0.52 & 6024\end{array}$ $68.42 \quad 66.24$ $\begin{array}{ll}0.59 & 0.61\end{array}$ $\begin{array}{rr}4.08 & 4.68 \\ 95.81 & 96.46\end{array}$ $95.81 \quad 96.46$ $\begin{array}{rr}0.000 & 0.018 \\ 1.533 & 1.430\end{array}$ \begin{tabular}{ll}
1.533 & 1.430 \\
3.931 & 4.234 \\
\hline & .500
\end{tabular} $6.560 \quad 5.824$ $10.024 \quad 10.099$ $\begin{array}{ll}1.763 & 2.006 \\ 0.144 & 0.148\end{array}$ $\begin{array}{ll}0.045 & 0.240 \\ 24.000 & 24000\end{array}$ 
Table 4. Selected analyses of minerals. C, Ilmenite

\section{Manengouba, stage 2}

\#

Petrographica

1 facies

Mineral type microcryst phenocryst phenocryst microcryst

\section{Manengouba, stage 3}

EL4 Eb17 KNS1

Bn Bn Tr

phenocryst microcryst iicrophenocryst

$\begin{array}{lll}0.00 & 0.00 \quad 0.00\end{array}$

$\begin{array}{ccc}0.00 & 0.00 & 0.00 \\ 48.92 & 51.12 & 47.68\end{array}$

$\begin{array}{ccc}48.92 & 51.12 & 47.68 \\ 0.47 & 0.04 & 0.03\end{array}$

$\begin{array}{lll}0.00 & 0.00 \quad 0.00\end{array}$

$\begin{array}{lll}44.44 & 44.69 \quad 45.68\end{array}$

$\begin{array}{lll}0.64 & 1.38 & 2.09\end{array}$

$\begin{array}{lll}5.45 & 0.86 & 0.00\end{array}$

$\begin{array}{lll}0.05 & 0.05 & 0.00\end{array}$

$\begin{array}{lll}99.97 & 98.14 & 95.48\end{array}$

$\begin{array}{lll}0.000 & 0.000 \quad 0.000\end{array}$

$\begin{array}{lll}0.027 & 0.002 & 0.002\end{array}$

$\begin{array}{lll}1.770 & 1.962 & 1.891\end{array}$

$\begin{array}{lll}0.424 & 0.072 & 0.217\end{array}$

$\begin{array}{lll}1.364 & 1.836 & 1.798\end{array}$

$\begin{array}{lll}0.391 & 0.065 & 0.000\end{array}$

$\begin{array}{lll}0.026 & 0.060 & 0.093\end{array}$

$\begin{array}{lll}0.000 & 0.000 \quad 0.000\end{array}$

$\begin{array}{lll}0.003 & 0.003 & 0.000 \\ 4.002 & 3.998 & 4.000\end{array}$

\section{Manengouba, stage 4}

Eb20 Eb14

Alk-B $\mathrm{M}$

phenocryst phenocryst phenocryst

corr
0.05

$\begin{array}{lll}0.00 & 0.00 & 0.03\end{array}$

$\begin{array}{lll}07.92 & 49.88 & 49.15\end{array}$

$\begin{array}{llll}0.08 & 0.00 & 0.03 & 0.40\end{array}$

$\begin{array}{cccc}0.00 & 0.00 & 0.15 & 0.10 \\ 44.30 & 46.89 & 46.64 & 42.88\end{array}$

$\begin{array}{ll}1.32 & 0.80-\quad 46.64\end{array}$

$\begin{array}{lll}1.94 & 1.10 & 1.14\end{array}$

$\begin{array}{ccc}95.67 & 98.67 & 9.00 \\ & & 98.00\end{array}$

$\begin{array}{llll}0.003 & 0.000 & 0.000 & 0.001 \\ 0.005 & 0.000 & 0.002 & 0.023\end{array}$

$\begin{array}{llll}0.005 & 0.000 & 0.002 & 0.023 \\ 1.867 & 1.898 & 1.882 & 1.815\end{array}$

$\begin{array}{llll}0.258 & 0.204 & 0.225 & 0.334\end{array}$

$\begin{array}{llll}1.661 & 1.781 & 1.761 & 1.437\end{array}$

$\begin{array}{llll}0.150 & 0.083 & 0.087 & 0.370\end{array}$

$\begin{array}{llll}0.058 & 0.034 & 0.038 & 0.018\end{array}$

$\begin{array}{llll}0.000 & 0.000 & 0.006 & 0.004\end{array}$

$\begin{array}{llll}0.003 & 0.000 & 0.000 & 0.004\end{array}$

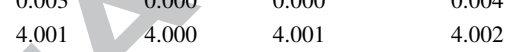




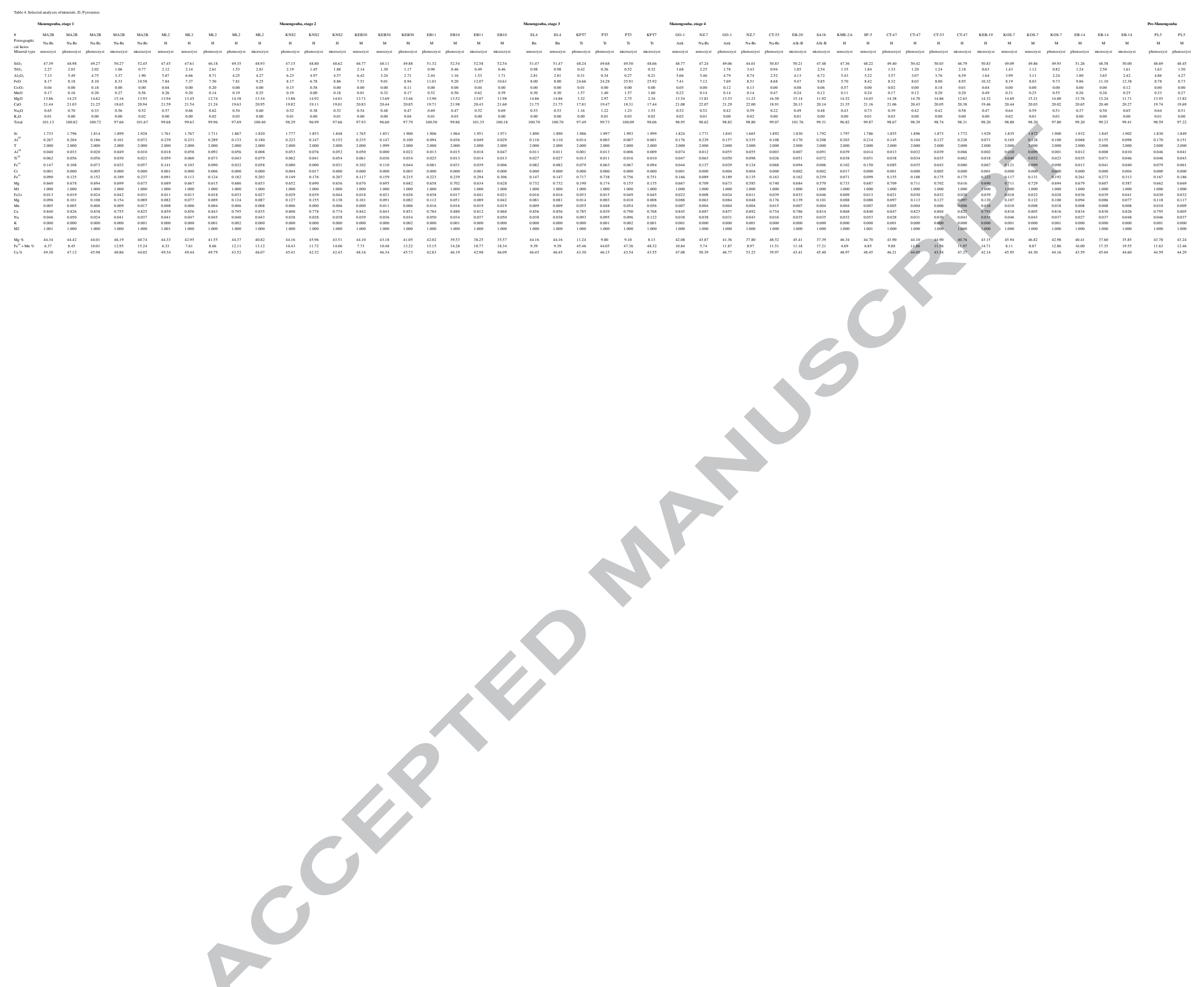


Table 4. Selected analyses of minerals. E, Amphibole

Manengouba, stage 2

\begin{tabular}{|c|c|c|c|c|}
\hline \# & EB11 & $\mathrm{Eb} 10$ & $\mathrm{~Eb} 10$ & $\mathrm{~Eb} 10$ \\
\hline $\begin{array}{l}\text { Petrographical } \\
\text { facies }\end{array}$ & M & M & M & $\mathrm{M}$ \\
\hline Mineral type & $\begin{array}{l}\text { nicrophenocrys } \\
\text { Edenite }\end{array}$ & $\begin{array}{l}\text { phenocryst } \\
\text { Kaersutite }\end{array}$ & $\begin{array}{l}\text { phenocryst } \\
\text { Kaersutite }\end{array}$ & $\begin{array}{l}\text { phenocryst } \\
\text { Kaersutite }\end{array}$ \\
\hline
\end{tabular}

Adv

Manengouba, stage 4

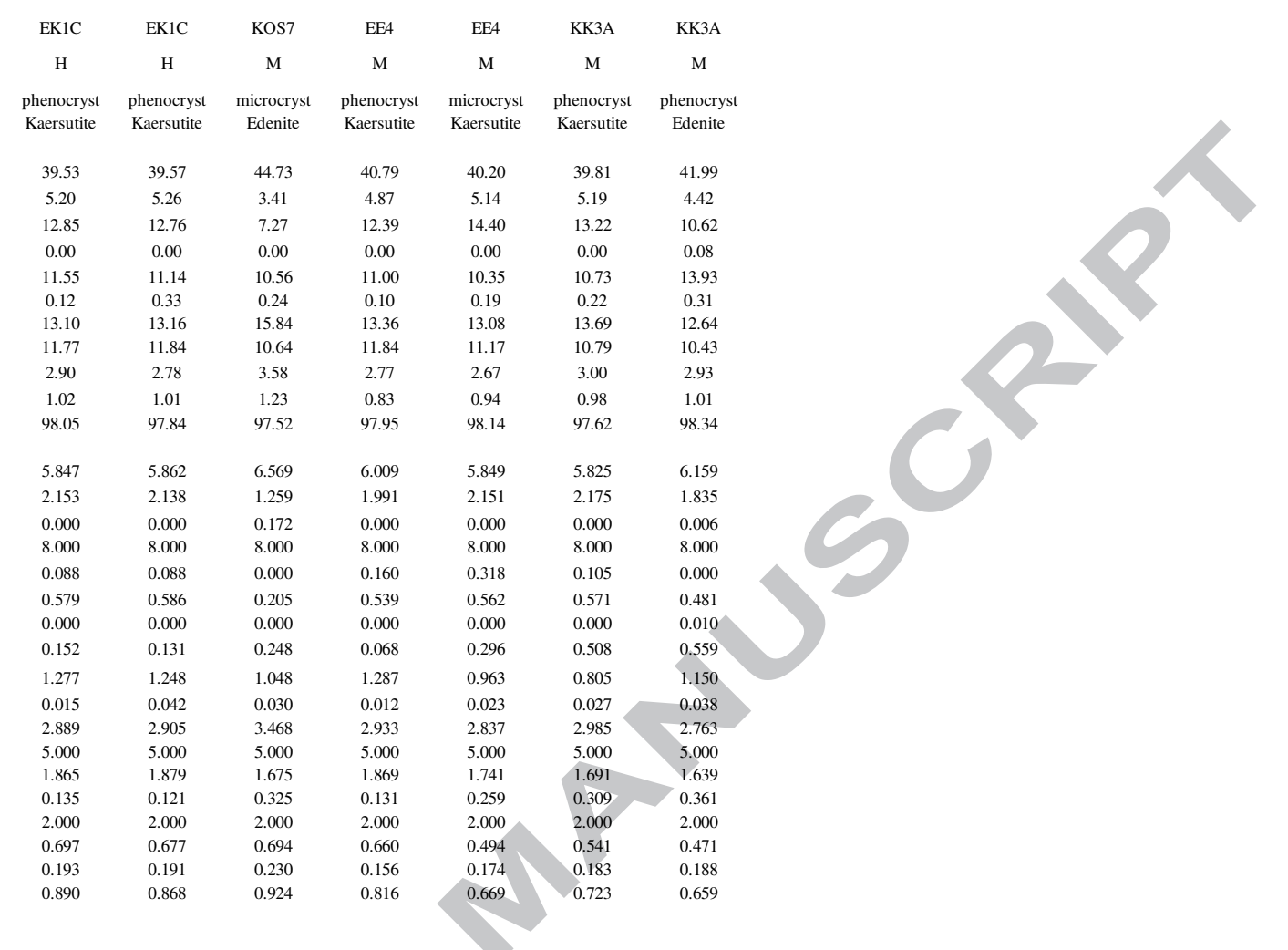


Table 4. Selected analyses of minerals. F, Mica

Manengouba, stage 2

Petrographical

facies

Mineral type

Eb11

M

Eb11

M

phenocryst phenocryst

$\mathrm{SiO}_{2}$

$\mathrm{TiO}_{2}$

$\mathrm{Al}_{2} \mathrm{O}_{3}$

$\mathrm{Cr}_{2} \mathrm{O}_{3}$

$\mathrm{FeO}$

$\mathrm{MgO}$

$\mathrm{MnO}$

$\mathrm{Na}_{2} \mathrm{O}$

$\mathrm{K}_{2} \mathrm{O}$

Total

$\mathrm{Si}$

$\mathrm{Al}^{\mathrm{IV}}$

Total

$\mathrm{Al}^{\mathrm{VI}}$

$\mathrm{Ti}$

$\mathrm{Mg}$

$\mathrm{Mn}$

Total

K

$\mathrm{Na}$

Total
Manengouba, stage 4

M M

microphenocrys microcryst

$\begin{array}{cc}39.60 & 39.27 \\ 4.99 & 5.74 \\ 11.97 & 12.36 \\ 0.00 & 0.00 \\ 9.51 & 10.02 \\ 19.60 & 18.54 \\ 0.01 & 0.03 \\ 0.13 & 0.11 \\ 1.40 & 1.02 \\ 8.49 & 8.60 \\ 95.70 & 95.69 \\ & \\ 3.128 & 3.107 \\ 0.872 & 0.893 \\ 4.000 & 4.000 \\ 0.241 & 0.260 \\ 0.296 & 0.342 \\ 0.628 & 0.663 \\ 2.308 & 2.187 \\ 0.009 & 0.008 \\ 3.482 & 3.459 \\ 0.857 & 0.870 \\ 0.215 & 0.156 \\ 1.072 & 1.026 \\ & \end{array}$



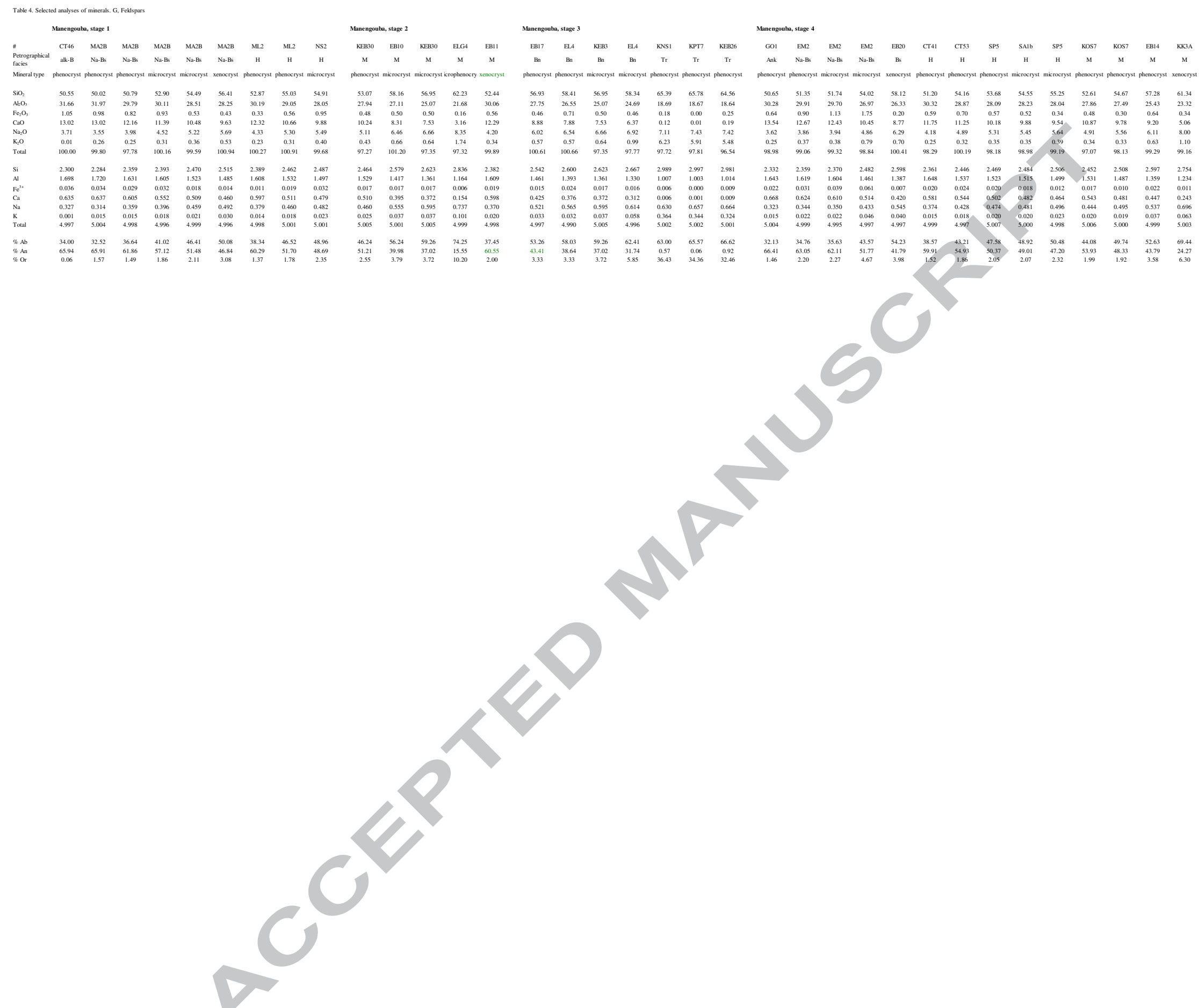


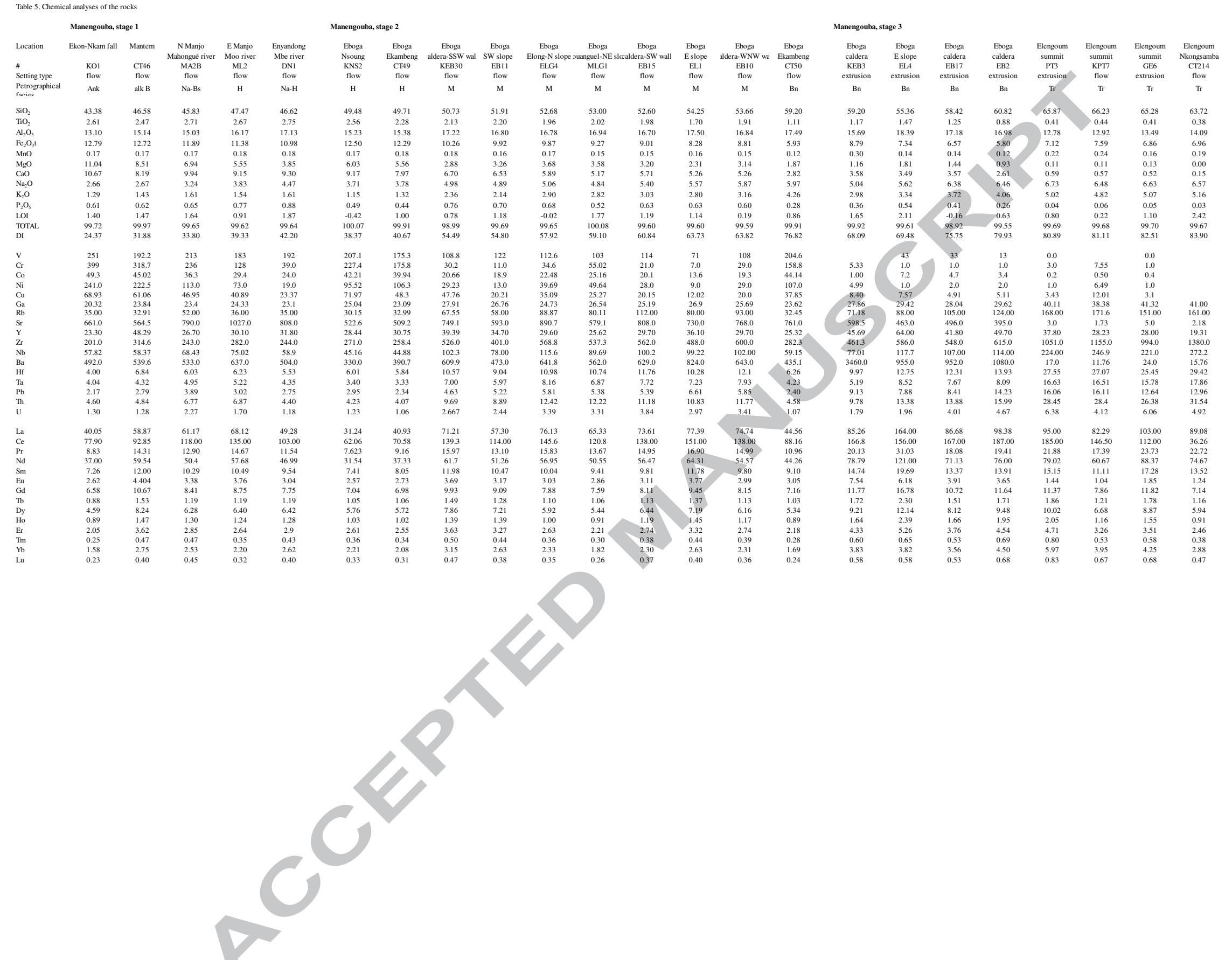




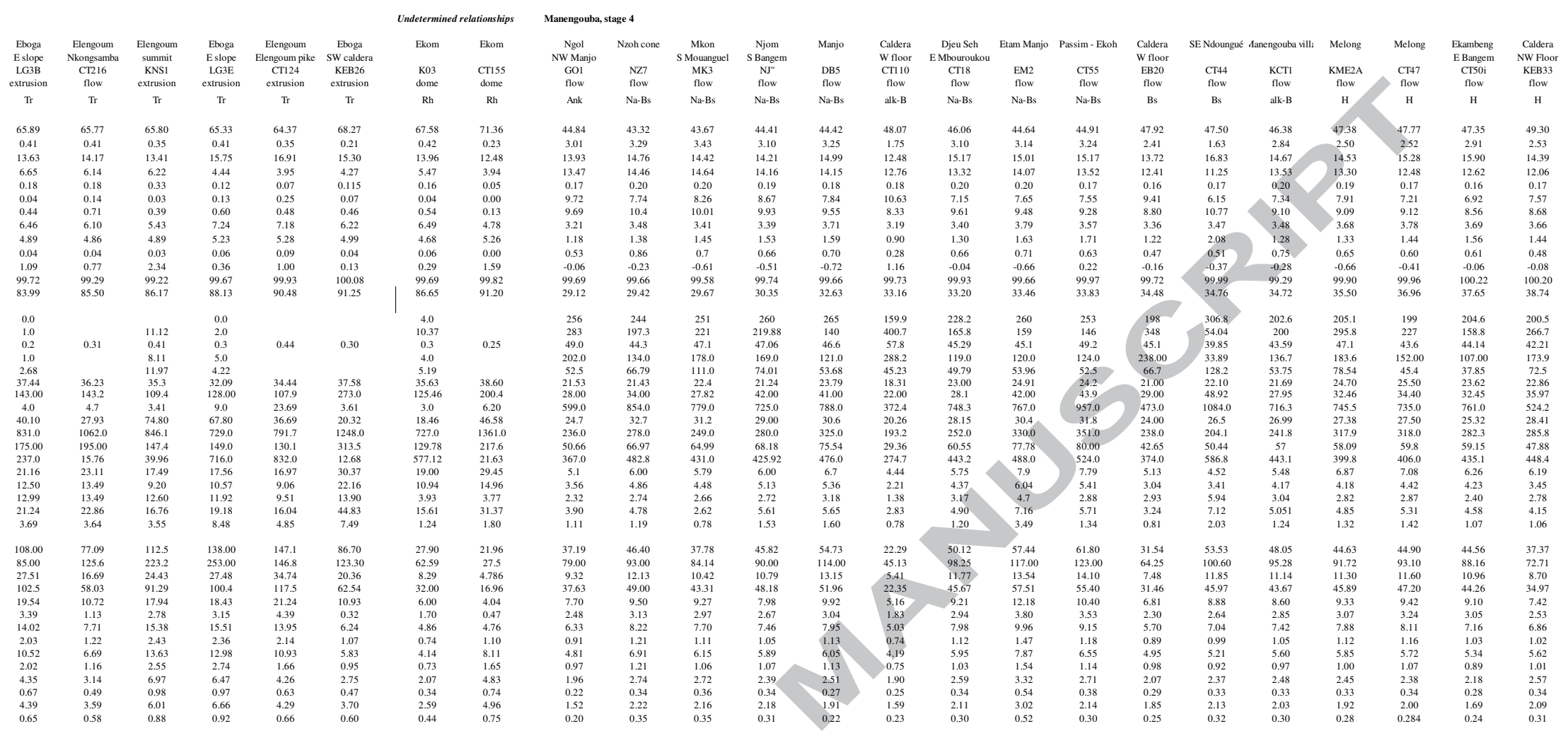




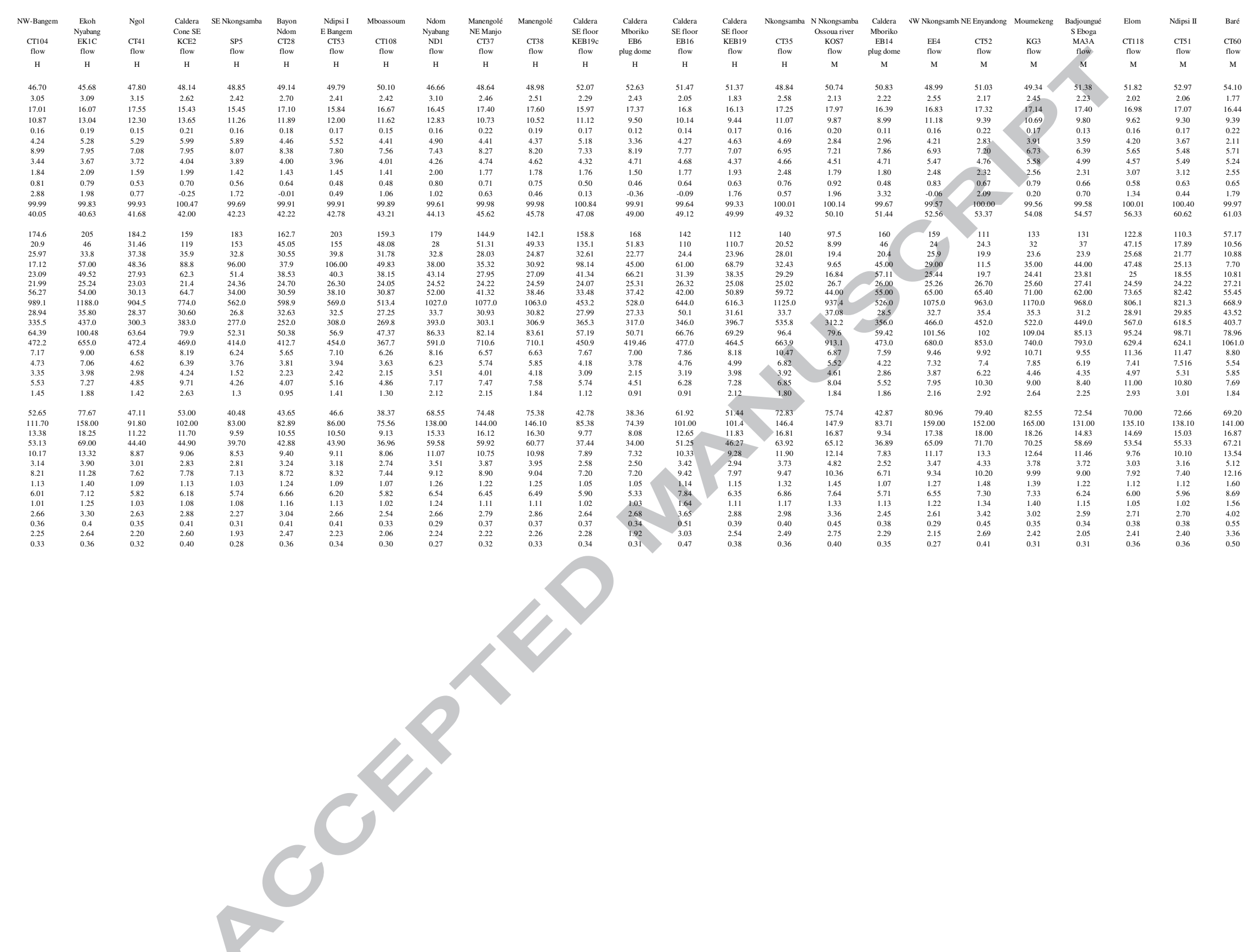




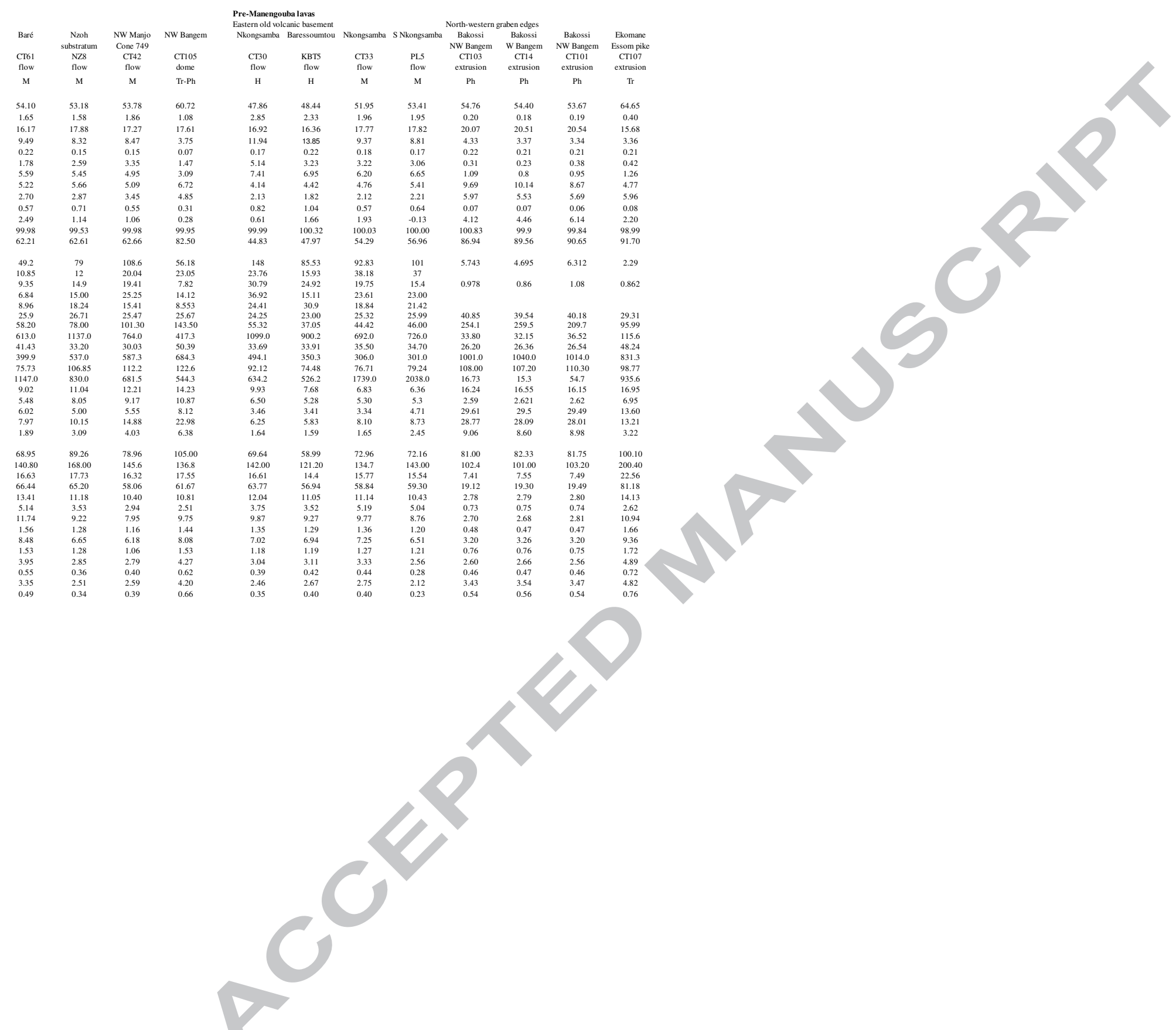

